Florida International University FIU Digital Commons

4-30-1999

\title{
An interview study of community college student perspectives on service-learning
}

Richard Appelbaum

Florida International University

DOI: $10.25148 /$ etd.FI14032328

Follow this and additional works at: https://digitalcommons.fiu.edu/etd

Part of the Higher Education Commons

\section{Recommended Citation}

Appelbaum, Richard, "An interview study of community college student perspectives on service-learning" (1999). FIU Electronic Theses and Dissertations. 1299.

https://digitalcommons.fiu.edu/etd/1299

This work is brought to you for free and open access by the University Graduate School at FIU Digital Commons. It has been accepted for inclusion in FIU Electronic Theses and Dissertations by an authorized administrator of FIU Digital Commons. For more information, please contact dcc@fiu.edu. 


\title{
FLORIDA INTERNATIONAL UNIVERSITY
}

Miami, Florida

\section{AN INTERVIEW STUDY OF COMMUNITY COLLEGE STUDENT PERSPECTIVES ON SERVICE-LEARNING}

\author{
A dissertation submitted in partial fulfillment of the \\ requirements for the degree of \\ DOCTOR OF EDUCATION \\ in \\ HIGHER EDUCATION
}

by

Richard Appelbaum 
To: $\quad$ Acting Dean, Robert Vos

College of Education

This dissertation, written by Richard Appelbaum, and entitled An Interview Study of Community College Student Perspectives on Service-Learning, having been approved in respect to style and intellectual content, is referred to you for judgement.

We have read this dissertation and recommend that it be approved.

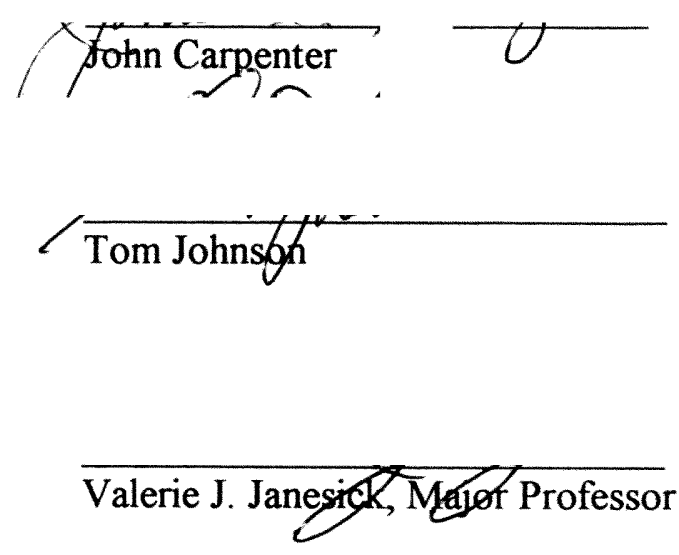

Date of Defense: April 30, 1999

The dissertation of Richard Appelbaum is approved.

Acting Dean, Robert Vos
College of Education

Dean Richard L. Campbell

Division of Graduate Studies

Florida International University, 1999 


\section{DEDICATION}

This dissertation is dedicated to the memory of my mother, Pauline, who believed in my ability to succeed at whatever I attempted. Since her passing, everything sweet in life is now bittersweet.

I also dedicate this dissertation to my wife, Josefina, my life partner and fellow educator, who supported my passion for this project, and to my daughter, Elisa Justine Appelbaum-Hoo. While my wife and I have given her a foundation based on the past, she, in turn, has been leading us into the future. Her computer knowledge helped save me on more than one occasion during this dissertation process. 


\section{ACKNOWLEDGMENTS}

I owe a large debt of gratitude to a few very special people who made it possible for me to complete this study. My major professor, Dr. Valerie J. Janesick, gave me a new sense of sight and voice that I can now share with my students. She inspired me to "stretch" mentally. To the other members of my dissertation committee, Dr. John Carpenter and Dr. Tom Johnson, I owe a warm "thank you" for their encouragement and for posing thought provoking questions for me to consider during the process of this study.

Thanks also go to the five students who participated in this study and didn't give up through the three sets of interviews and endless phone calls and visits to search for yet more insightful information and, finally, to discuss the findings and their meanings.

To all of the professionals in service-learning who shared information and valuable time on the telephone and in cyberspace, I am also indebted.

Finally, I wish to thank Dr. Joe Cook who encouraged me to pursue an FIU doctorate. If not for him, I would never have met the knowledgeable and caring professors and staff who I had the pleasure of spending quality time with over the past few years.

This entire doctoral process has been a labor of love. 


\title{
ABSTRACT OF THE DISSERTATION \\ AN INTERVIEW STUDY OF STUDENT PERSPECTIVES \\ ON SERVICE-LEARNING
}

by

\author{
Richard Appelbaum \\ Florida International University, 1999 \\ Miami, Florida \\ Professor Valerie J. Janesick, Major Professor
}

Over the past two decades, the community college in the United States has boasted a leadership role in the movement to make education community-based and performance-oriented. This has led to an intensification in attempts to search for more innovative means to make education more experiential and relevant to students' lived experiences.

One such innovative program that holds promise to meet this challenge is service- learning. This paradigm attempts to relate the academic education in the classroom to community-based problems, which fits in neatly with the community-based characteristics of the community college. It promises to link ideas developed in the classroom and their practical application within the community through guided reflection. It is designed to enhance and enrich student learning of course material by combining citizenship, academic subjects, skills, and values.

Though many studies have been carried out in regard to the outcomes of servicelearning through quantitative means, relatively few qualitative studies are available, and those available have primarily studied traditional students at four-year residential colleges or universities. Therefore, there is an urgent need to study non-traditional students' perspectives at the community college level. 
The purpose of this study was to describe and explain the perspectives of five students at Broward Community College, Central Campus, Ft. Lauderdale, Florida. The following exploratory questions guided this study:

1. What elements constitute these students' perspectives?

2. What variables influence their perspectives?

3. What beliefs do these students hold about their service-learning experience which support or are contrary to their perspectives?

This ethnographic interview study was conducted over a period of twelve months and consisted of three interviews for each of the five participants. The analysis of the data was conducted following the stringent principles of ethnographic research which included constant comparative analysis. The interviews were tape recorded with the participants' permission, transcribed verbatim, and organized into categories for in-depth understanding. Furthermore, these categories were developed from the data collected and an organizational scheme for understanding and interpreting of these perspectives emerged. The researcher, as well, kept a reflective journal of the research process as part of the data set.

The results of this study show the need for a better grasp of the concepts of service-learning on the part of all involved with its implementation. In spite of this, all of the participants displayed gains to a greater or lesser degree in personal growth, academic skills, and citizenship skills. 


\section{TABLE OF CONTENTS}

CHAPTER

PAGE

I. INTRODUCTION

Background of the Problem

Service-Learning Defined.

Statement of the Problem............................ 7

Purpose of the Study................................. 8

Framing the Research Questions................... 9

II. REVIEW OF RELATED LITERATURE................... 10

Introduction...................................... 10

Experiential Learning...................... $\quad 10$

A Brief History of Service-Learning.......... 16

Service-Learning in Higher Education........ 22

III. METHDOLOGY..................................... $\quad 37$

Introduction................................... $\quad 37$

Underlying Assumptions.......................... $\quad 37$

Sample.......................................... $\quad 39$

Design............................................ 43

Data Analysis.................................... $\quad 46$

Role of the Researcher............................. 48

The Pilot Study................................... $\quad 52$

IV. PRESENTATION OF THE DATA........................ 57

Organization of Categories.......................... 59

Susan's Perspective................................. 61

Personal Growth............................. 63

Academic Skills ............................ $\quad 66$

Citizenship Skills............................. 68

Ellen's Perspective................................. $\quad 70$

Personal Growth.............................. $\quad 74$

Academic Skills .............................. $\quad 77$

Citizenship Skills........................... $\quad 79$ 
Siri's Perspective.................................... 83

Personal Growth........................... $\quad 86$

Academic Skills............................... $\quad 89$

Citizenship Skills........................... $\quad 92$

Nestor's Perspective................................. 93

Personal Growth............................... $\quad 95$

Academic Skills.............................. 98

Citizenship Skills............................. 100

Glenda's Perspective.................................. 103

Personal Growth.............................. 105

Academic Skills............................. 108

Citizenship Skills............................ $\quad 110$

Summary............................................ 113

The Role of the Researcher Revisited................. 114

V. CONCLUSIONS, IMPLICATIONS, and RECOMMENDATIONS............................... 118

Introduction........................................ 118

Participants' Perspectives on Exploratory Questions..... 121

Conclusions........................................ 126

Implications and Recommendations................... 129

The Importance of Reflection......................... 131

The Issue of Ethics Revisited........................ 134

Implications for Administration,

Staff, Faculty, and Students......................... 136

Implications for Future Research.................... 141

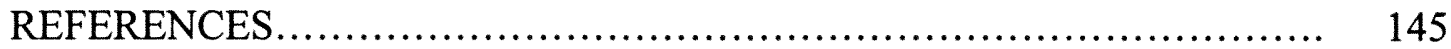

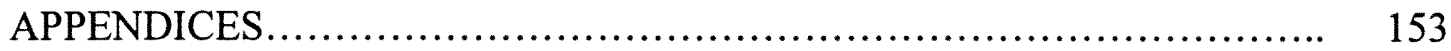

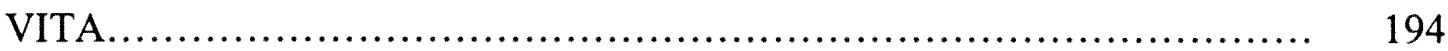




\section{LIST OF FIGURES}

Figure 1.1 BCC Remedial Results......................... 6

Figure 2.1 The Service-Learning Continuum................. 28

Figure 2.2 Overview of Related Theoretical Research

With Undergraduates Related to Service-

Learning and Experiential Education...............

Figure 4.1 Participants' Perspectives on service-Learning....

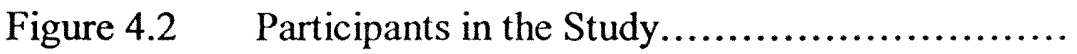

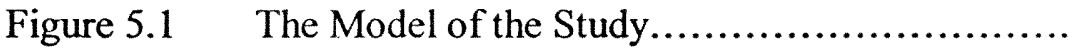


Chapter I

Introduction and Background

Over the past two decades, the community college in the United States has boasted a leadership role in the movement to make education throughout the nation community- based and performance-oriented predicated on its open-door policy. This policy, however, has come under scrutiny and, in many cases, has been criticized as being more of a "revolving-door" than an "open-door" in light of the high rate of attrition among its student population (Pascarella \& Terenzini, 1991). Because of this, there has been an intensification in attempts at self-assessment and program evaluation to search for better and more innovative means to increase retention (Bumphus, 1996). Any such attempts, however, will not be successful until community college administrators and faculty are willing to work together to make the educational experience of their students more practical and demonstrate to students that their coursework can help lead them to more meaningful and productive lives. At the same time, students must understand that they are expected to take a proactive part in their education. They must realize that they are responsible for making this experience meaningful and positive. When this scenario becomes a reality, innovative programs may hold the promise of helping to address current criticisms and lead the way to positive change.

One such innovative program available to community colleges that holds promise is service-learning which attempts to relate the education in the classroom to communitybased problems. This fits in neatly with the community-based characteristics of the community college (Gleazer, 1995). Since students have been calling for more relevancy in their formal education including more active learning, this model program could be a valuable alternative to traditional ones that are still in use. It will take more than lip- 
service on the part of a college administration to successfully implement such a program.

Faculty and students will only take it seriously if they feel that there is college-wide support. A strong infrastructure must be in place that is willing to answer very challenging questions. Is the administration financing the program adequately? Is the administration providing leadership? Does the faculty realize and support the need for service-learning? Is the faculty receiving sufficient training to make service-learning part of the curriculum? Does everyone involved, including the students, have a clear understanding of the nature and responsibilities of service-learning?

\section{Service-Learning Defined}

Service-learning is defined by the Corporation on National and Community Service as a method through which citizenship, academic subjects, skills, and values are taught. It involves active learning including drawing lessons from the experience of performing service work. Service-learning differs from community service, volunteer work, practica, or internships in its explicit linking of theory to practice. More specifically, it links ideas developed in the classroom and their practical application within the community through guided reflection. It is a strategy which is designed to enhance and enrich student learning of course material. Therefore, service-learning appears to be a valuable tool in the retention of community college students since it claims to link coursework to life experiences, career exploration, and employment opportunities. In helping students discover and develop skills, it may help to develop self-esteem, the real self-esteem that comes from achieving something that is challenging, and self-confidence, as well as relate personal development to civic responsibility which 
is sorely lacking in our society. An example of this is found in "A Student's Reflections on Service" by Jeremy Wisnewski, a graduate of Piedmont Virginia Community College in Charlottesville, VA. and reported on the American Association of Community College's home page, Community College Times (1997). Mr. Wisnewski shares with the reader the fact that college students cannot afford to be ignorant of the world around them, and that in too many instances the routine of daily life clouds "the larger picture." He found that doing service-learning in a local elementary school helped him see the importance of caring for the real people with whom he made contact, and he wanted to share this insight with the elementary school students. He taught himself and them through the ancient Chinese game of "go" how to get involved in life, how to resolve problems, and how to be content. Wisnewski explains the basic concept behind the game as teaching a deep sense of fairness and community. The players win and lose equal numbers of times. Cooperation is emphasized, and egos are not allowed to get in the way. In the game, a pattern of stones emerge on a wooden playing board in an almost artistic pattern. All plays are of mutual benefit, and each player's set of stones "grows" in relation to the other players' actions. When the board crowds with stones, there is a conflict, but in the end, all the stones are still and satisfied with the process. The game teaches that we must engage in the world in which we live. We must accept struggle and use it to progress. This is the essence of service, to engage in the world to create change. He goes on to say that this service experience led him to see the need to take responsibility for the world around him and to help make his community a better place. His in-depth reflections and the excellence of his academic work, supported by his service-learning experience, led to a bachelor's degree from College of William and Mary and offers for full scholarships into Ph.D. programs at several universities. $\mathrm{He}$ sums up his experience by saying that service-learning made a change in his life that helped him make a change in his community. 
I recall Marie Curie saying that humans are only able to improve the world when they work to improve the individual human through education. It is necessary, she added, that each one of us works for her/his own improvement and, at the same time, takes a shared responsibility for all humanity. This to me is the essence of service-learning which is made real by such students as Jeremy Wisnewski.

A majority of the younger students who enter the community college are too often obsessed with "defeat, despair, denial, distrust, danger, and dysfunction" which has been aptly labeled "living life in the key of D" (Oldenberg, 1990). Traditional modes of teaching course matter do not address these matters and, consequently, do not make an impact on many of these students because they are not traditional students. These students are more impressed by their experiences that take place outside the school. According to Wilson (1966), more than $70 \%$ of what students learn during their college years is a direct result of out-of-class experiences. Moffatt (1988) supported this observation:

For about $40 \%$ of students, the do-it-yourself side of college [what took place outside the classroom] was the most significant educational experience. And for all but $10 \%$, extra-curricular learning had been at least half of what contributed to their maturation so far in college (p.58).

If we truly wish to prepare these students to live a life that has positive value both to themselves and society, we must help them change this foreboding key of $\mathrm{D}$ to the key of $\mathrm{C}$, so that they learn to value change, choice, capabilities, cooperation, collaboration, compromise, connectedness, and community. Application of a service-learning pedagogy seems to be an effective alternative strategy to introduce these key of $\mathrm{C}$ values in the college curriculum.

The mission statements of community colleges often include the intrinsically 
intertwined nature of the college to the community in which they exist and make mention of the benefits of that relationship to address social ills such as illiteracy, homelessness, dropouts, teen pregnancy, substance abuse, juvenile crime, child abuse, and problems facing the elderly (Harkavy, 1995). A high percentage of community college students faces these realities every day of their lives. Not to address these issues in the context of their coursework is an oversight that educators cannot afford to make. What better way is there for community colleges to address these social ills if not through the curriculum?

In addition to this, community colleges are concerned with the decline in academic standards. In Florida, institutions of higher education have been mandated to assess the effectiveness of their programs including college readiness skills. In 1992, almost $60 \%$ of all FTIC (first time in college) students who were tested statewide failed at least one of three sections on the test (College Preparatory Success Rate Report, 1996, p.2). This clearly indicates that traditional paradigms of teaching have not been successful with a majority of prospective community college students. If they haven't been successful, why continue down the same disastrous path? What can we as educators do to counteract this negative trend? The current situation points out the need to pursue innovation in our curricular offerings.

At Broward Community College, $93 \%$ of all FTIC students must take at least one college preparatory course based on their placement test scores (Feng, 1996). The 1995 Florida Community College Accountability Report demonstrates that the percentage of students at Broward Community College who had completed the highest level required preparatory course within two years of entering the college was only $69.14 \%$ in reading, $61.52 \%$ in writing, and $31.78 \%$ in math. These figures have recently been updated for the 1998 school year (Figure 1.1). They tell us that a significantly high percentage of students will probably not graduate and be caught in the proverbial "revolving-door". Are we asking ourselves what these figures mean and what they tell us? If we are 
concerned, we will, as professionals, seek answers and alternatives to this dismal situation. To allow such trends to continue reflects on our ability (or inability) to educate. We must not throw up our hands in defeat, nor must we lay blame on others. In the college, it is our duty to confront this situation and deal with it. We need to assess our programs continually as a kind of action research and, obviously, involve the students in the process. This assessment process must be more than statistical response to standardized questions; it must be a moral activity (Brown \& Knight, 1994). Educators have to assess inter-personal qualities which are not self-evident and are a matter of values. This assessment by necessity will ask us to be honest with ourselves. One of the first issues we must face is the arcane nature of traditional paradigms which isolate students from the practicalities of life. If we do not assess our curriculum in all seriousness, we will make ourselves diminished participants in our own communities.

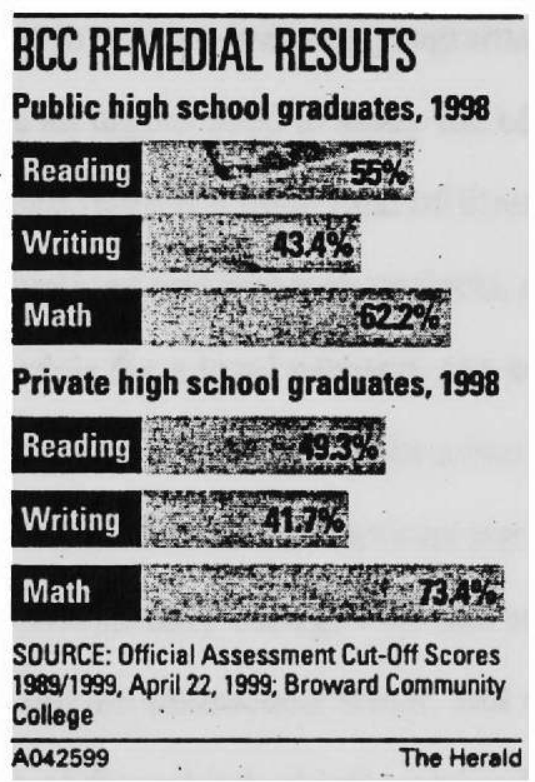

Figure 1.1

With the specter of performance-based funding resting on the number of 
successful completers hanging over their heads, Florida community college leaders have grave decisions to make. How do community colleges assist under-prepared students in completing their coursework? What strategies can be implemented to stimulate student interest in succeeding? In other words, how do we make the open-door policy really work? Many educators are recommending service-learning as a potent antidote to today's crisis (Enos \& Troppe, 1996). As concerned educators, we must determine its efficacy in relation to the current situation.

\section{Statement of the Problem}

With the growth of national interest in service-learning and the increase in the number of students taking part in service-learning programs as part of their higher education experience, there is an urgent need to study the effects of service-learning on student development. Although there is a great deal of literature on service-learning and a number of informative evaluations and research projects, there are very few research studies that could serve as models for a local program at a community college. Methods used in a university setting are often poorly suited for a two-year college. Historically, community colleges have not been research institutions nor do they foster research; therefore, the perspectives of community college students relating to the value of their service-learning experiences remain untouched, silent, and unpublished.

Not only is a majority of the published information based on university studies, but it tends to isolate the relationship among intellectual, social, and emotional elements based on the assumption that: 1) faculty deal solely with intellectual development, and 2) student affairs professionals deal solely with social and emotional development with no 
linkages between the two (Cove $\&$ Love, 1996). As a result, we are not getting a complete picture of the situation. What we have is fragmented. There is a need to present studies that incorporate social, emotional, and intellectual elements as a whole.

Also, those studies that are published are quantitative in nature and treat students as unseen and unheard numbers. There is a need, as well, to hear from the students themselves in order to seek clear meaning and value in the service-learning experience in their unique voices. Moreover, we need in-depth interview studies that do not settle for superficial comments or "yes", "no" responses that do not provide insight. It is necessary that we delineate more specifically what students as individuals are getting out of their service-learning experience, and the impact this experience has had on them as students, individuals, and members of society. In addition, it is important to know if the results of their experiences support the application and expansion of this pedagogy as an effective alternative strategy to teach course material and increase civic responsibility. But, as an educator, I can never truly presume to understand the students' experiences until I enter into a dialog with each one of them. One that unites us in a common goal in which, as Paulo Freire suggested, I can read their world, as well as the word (Freire \& Macedo, 1987). In order to provide information on student perspectives of their service-learning experiences, I carried out an interview study of five Broward Community College students who have taken one or more courses with a service-learning component in which service-learning was combined together with the course curriculum.

\section{Purpose of the Study}

The purpose of this study was to describe and explain selected community college 
students' perspectives on service-learning . This study was guided by three exploratory questions:

1) What elements constitute these students' perspectives?

2) What variables influence their perspectives?

3) What beliefs do these students hold about their service-learning experience which support or are contrary to their perspectives?

A prime focus of this study was to ascertain the credibility and viability of service-learning as a valid alternative method in the community college experience as viewed from the students' perspectives since solid evidence has yet to be forwarded. 
Chapter II

Review of Related Literature

Introduction

This review of the literature deals with three parts. The chapter commences with an analysis of the concept of experiential learning, a paradigm which may be useful in the integration of service-learning as a learning style, especially in the community college. Next, literature concerned with the history of service-learning as an educational model, followed by the third part which includes service-learning initiatives in higher education, community colleges in general, and Broward Community College in particular.

To review the literature reminds me of Mrs. Ramsay's dinner party in Virginia Woolf's To the Lighthouse, in which Mrs. Ramsay provides her summary version of the conversations and adds her own unique contributions to them. I cannot claim to be as witty as Virginia Woolf and her characters, but I do hope to add insight to the issue of service-learning and its value to the current educational scene in our society.

\section{Part One: Experiential Learning}

I believe that all education proceeds by the participation of the individual in the social consciousness of the race. John Dewey 
Everything old seems new again. By that I allude to the recent normalization of experiential learning in the educational lives of students on all levels by means of servicelearning. Though many current educational philosophers, or at least theorists, would like to believe that they were instrumental in this endeavor, it was actually Herman Schneider, at the University of Cincinnati, who used practical work experience within the context of undergraduate courses in engineering early in this century (Wade, 1994). Since then, there have been a number of attempts to connect formal learning to students' life experiences.

For example, the educational philosophy of John Dewey, Ralph Tyler, and Hilda Taba emphasized the importance of integrating learning experiences into the curriculum to provide a framework for learning activities. These educators, as well as Piaget, Coleman, and Kolb have urged teachers to instruct through students' experiences. Dewey in John Dewey on Education maintained: "The mind is not individual but social, and learning is a by-product of social activities" (p.355). Dewey believed that all curriculum must be generated out of social situations based on organized principles but founded on the twin pillars of the capacity of the child and the demands of the environment (Kinsley and McPherson, 1995). Dewey's philosophy was looked upon by many in the educational community as radical. For the early 1900 's it was, and in some cases, it seems it still is. It doesn't sit well with the philosophy of the radical right. But, Dewey's philosophy fits perfectly with the American radical tradition. It is his "Intelligent Action" and his thorough-going naturalism that can help save American education. It is time for America to rediscover the work of John Dewey.

Tyler (1949) affirmed that learning occurs "through the active behavior of the student; it is what he does that he learns, not what the teacher does" (p.63). In his Eight Year Project, Tyler demonstrated his belief that students benefit academically, 
personally, and socially from learning experiences in the community. Similarly, Taba (1962) provided an in-depth approach to the process of curriculum development. Her analysis and descriptions of content organization and design provided concrete ways to produce curriculum that actively engaged students in the learning process. She urged professionals at all levels of education to use the concerns of the student learners to increase motivation and connect the essential elements of education.

A contemporary variation on this theme is "constructivist theory," which suggests that "people are not recorders of information, but builders of knowledge structures" (Resnick and Klopfer, 1989, p.4). In this theory, the role of the teacher is redefined as guiding student activity and providing examples and counter-examples rather than "directing" and "telling." Basically, this prepares the student to be a reflective learner who not only takes control of her/his education but assumes responsibility for what she/he learns and displays an intrinsic interest in lifelong learning. Obviously this clearly relates to service-learning which incorporates setting objectives for skills to be mastered, planning projects that contribute to the learning experience, and, at the same time, getting a job done that the student, instructor, and agency can evaluate, analyze, and draw lessons from. This process makes for an active learner and an active citizen. In my classes, students have gained a great deal of insight into service-learning from these suggested readings:

Boud, D., Keogh, R., and Walker, D. (Eds.). (1985). Reflection: Turning Experience into Learning. New York: Nichols.

Conrad, Daniel. (1982). Learning from Experience: A Guide for Student Reflection in Youth Participation Programs. New York National Commission for Resources for Youth.

Books such as these explain to the students in detail the value of experiential 
learning by providing clear examples and talk about reflection and demonstrate how to do it. These books serve as guides, roadmaps and present the students with a wealth of practical information. This is effective and exciting learning that extends beyond the classroom and helps create an active rather than a passive learning environment that makes practical and meaningful use of the academic content of formal school-based learning. If well planned, this constructivist theory can create an environment in which the student gains organizational, team, and problem-posing and -solving skills, as well as other valuable capabilities for future learning and work. This is lively learning in which service-learning is reconciled with academic achievement. There is a definite need for service-learning to be based on a firm theoretical foundation if it is not to be dismissed as just another expensive, time consuming hunch.

This is where John Dewey's theory of experience can have strong implications for service-learning. Dewey's theory of experience, in particular, is crucial for informing the current effort to create a theoretical base for service-learning if service-learning ever hopes to be taken seriously as more than just a type of add-on, extra-curricular program. But, what are the implications of Dewey's theory to the theory and practice of servicelearning? The primary characteristic is the "... organic connection between education and personal experience" (Dewey, 1938, p.25). Clearly, the issue here is, what constitutes a valid, educationally-sound experience? This led Dewey to develop criteria to define the educative quality of experience. And, it is this that service-learning must adhere to in its desire to utilize Dewey's dialectic that links experience and education. According to Dewey, the task of the educator is to determine the effects of the present experience on future experiences and to secure the educational value of these experiences by directing their growth. Dewey's writing can contribute to five specific areas of service-learning: 1) linking education to experience, 2) democratic community,3) reflective inquiry, 4) education for social transformation, and 5) social service. 
Dwight E. Giles, Jr., a leading voice in the field of service-learning in higher education, has recently written a few scholarly articles on the relationship of Dewey's theory of experience and its relationship to service-learning in hopes of further validating service-learning as an educational theory whose time has come and in hopes of ensuring quality in service-learning programs in light of negative press and faculty hostility. These detractors, on the whole, base their arguments on the view that objective scientific knowledge constitutes the only legitimate foundation for educational praxis. This outdated idea results in our living amongst ghosts in a tradition-bound locked cellar. The concept that real learning consists solely of observable and measurable behavior must be questioned by educators. Experiential learning is valid and integral to transformative learning. We have to liberate the curriculum from restrictive methodologies that tend to devalue significant qualities that happen not to be measurable.

The main issue that must be dealt with by service-learning advocates is to make sure that a true situational learning approach is practiced to ensure the quality of service and ensure rigor for the learning derived, as well, from the service experience (Sigmon, 1987). It might also be wise to locate service-learning within the broader educational endeavor which has been posed by Stanton in the form of a question: "Is service-learning a form of experiential education which can stand beside internships, field study and cooperative education? Or, is it a philosophy of experiential education which suggests methods and practices that should inform all programs" $(1987$, p.4)? Giles responds to this by taking his answer from Dewey's theory of experience, with its understanding that experience is ultimately social and communal and that education is interactive and reciprocal. He suggests the latter view of service-learning as a philosophy of experiential education rather than a more restrictive definition (Giles, 1988, pp.3,10). John Dewey was preoccupied with the disconnected elements in our lives. What could be more disconnected today than our educational system and its lack of practical application to 
life? Possibly, service-learning is the link that can help reconnect the need for service and learning. Benjamin Franklin said, "Tell me, and I forget. Teach me, and I may remember. Involve me, and I learn."

Likewise, Richard Battistoni (1995) of Providence College calls the connections that can be made in a service-learning context between practical experience and theoretical insight "quite powerful and useful in learning about citizenship in a pluralistic society" (p.33). It is paradoxical that faculty would seek to denigrate service-learning when, in fact, they clearly see that traditional methods do not work with contemporary students who appear to be less motivated and less prepared for academic study than previous generations of college students.

In a recent issue of Community College Week (1996, August 12), the Chancellor of Connecticut Community-Technical Colleges, Bruce Leslie, exhorted colleagues to "...understand that rapid change will be necessary if we are to fulfill the community college vision of the Twenty-first Century" (p.4). Among the factors that he feels must be taken into account in changing the way that community colleges teach are to realize that individuals learn best when they are involved in the process. He also states that disciplines only have meaning as part of a whole, in the context of the individual's life. Leslie adds that the key elements of learning are experiential and precede learning rather than vice-versa. Leslie is clearly suggesting that educators must be prepared to address different learning styles and expectations of students by adapting teaching styles to the needs of the students and the community. Isn't it clear that service-learning just may be able to accomplish this when one considers that it has such a strong background in proven theory and philosophy?

Similarly, Arthur Levine (1994) agrees that "active learning... is the preferred learning style of a quickly growing proportion of undergraduates" (p.5). A majority of these students seem to learn better from the bottom up, from concrete to abstract, rather 
than from top down as was the case with previous generations of students (Schroeder, 1993). This is especially true of community college students who tend to be concrete operational learners according to Jean Piaget's cognitive-structural theory of student development, and who do not do well with higher-level abstract reasoning which traditionally has been associated with college level studies (Gruber \& Voneche, 1977). This bottom-up method typifies experiential learning by which students learn inductively from observation and direct personal experience (Markus et.al., 1993). Thus, traditional methods will only create frustration and failure. What is the good of that?

For those faculty members who are determined to improve student success rates, service-learning can serve to support them in achieving "greater congruence between teaching styles and learning styles, thereby increasing the probability of students' ability to master content, acquire critical thinking skills, and understand increasingly complex issues" (Schroeder, 1993, p.26). At the same time, many student affairs professionals are being expected to assume increased responsibility in relation to student learning and performance-based outcomes assessment and to create partnerships with faculty in programs that value experiential learning and service applications of traditional courses (Komives, 1996). Obviously, as Schroeder said, "Learning is not a spectator sport" (1993, p.26). The question is whether the administration, faculty, student services staff, and students are willing to play ball with each other.

\section{Part Two: A Brief History of Service-Learning}

Currently, hundreds of schools in the U.S. are adopting service-learning with the evangelical fervor of new converts hell-bent on seeking out any new program that 
promises positive development in American education. Well, service-learning is not actually new to the American educational scene. For example, the literature claims that William Kilpatrick was the founder of school-based community service, having introduced the project method of learning at the end of World War I (Conrad and Hedin, 1991). But, the idea of community service goes back much further into America's past. Throughout the history of higher education in the United States, the concept of service has been used to warrant claims for public support. In his 1869 inaugural address, Charles William Eliot of Harvard asked rhetorically:

\begin{abstract}
And what will the University do for the community? First, it will make a rich return of learning, poetry and piety. Secondly, it will foster the sense of public duty--that great virtue which makes republics possible (Hofstader and Smith, 1961).
\end{abstract}

With the advent of new programs in American higher education, the move from classical curriculum to incorporate science and technology, for example, the rationale given was that this was needed to better serve the society. Andrew Draper focused on this approach in a 1907 commencement address when he stated, "The American university will carry the benefits of scientific research to the doors of the multitude" (Draper, 1907). More recently, Derek Bok (1982) captured the current tone of the debate:

By 1970 , then, the issues were clearly defined. Should universities turn inward and dedicate themselves to learning and research for their own sake, benefiting society indirectly through advances in basic knowledge and the education of able students? Should they continue instead to respond energetically to society's requests for new services, new training programs, and new forms of expert advice? Or should they take the initiative and set their own agenda for reform by deciding for themselves which programs to mount and which projects to encourage in order to bring about social change? 
Apparently, there can be no quick "yes" or "no" answers to such profound questions nor are there paradigms that can be expected to serve the individual situations at all colleges and universities. This matter of social responsibility must be one of continual debate for each college and university to enter. Cohen and Brawer (1982), who have written extensively about the American community college, feel that community service is especially important to the community college, and they invite community colleges to enter the debate as to the extent to which community service is or should be a major function at these institutions. How do colleges define themselves in relation to the community? How socially responsible should colleges be? How can this role of the college be clarified in order to carry out this mission effectively? These are questions we must answer.

It was the Progressives, like Dewey, who kept this approach to learning alive through the 1930's since they believed that the schools should inspire students with ethical values and the skills needed to create social reform (Conrad and Hedin, 1991). Their ideas are as relevant today as they were in the early part of the century. In order to include the pedagogy of service in higher education, possibly, there is a need to change the epistemology, the way we teach and learn, the way we know. It is the work of the Progressives that gives us the philosophical foundation we need. It affirms community, diversity, and engagement. Prior to the advent of progressivism, American education was based in purely academic learning using the rote-and-recitation model. Progressiveexperimentalists were the first to question this and move educational concerns from the elitist academic model to one which included social concerns and social activities in the curriculum that would bolster the school's role in teaching students to think and solve problems.

Outside of education, the long tradition of community service in America can be traced to other sources than just the university setting. Alexis de Tocqueville recorded in 
1830 the unique phenomenon of civil and social support that citizens gave the fledgling nation in his Democracy in America. He called these acts " habits of the heart" and saw these "habits" as a way to unify the political community and support social institutions (Bellah, Madsen, Sullivan, Swidler, and Tipton, 1986). In the past decade, his work has helped revive the great interest in community service as a fundamental and natural part of democracy and the idea of people helping and caring for each other. This then led political leaders to advocate for more involvement of youth in community service for the purpose of inculcating the values of responsibility to self and others in light of the growing isolation of individuals, the emphasis on self, and the lack of connection between young people and their neighborhoods and communities (Boyer, 1987). These political leaders have seen the need for community service as a vehicle for youth development, school reform, and community renewal. It is these politicians together with educational leaders such as Ernest Boyer who are highly concerned about the restructuring of American higher education. In the Chronicle of Higher Education (March, 1994), Boyer writes about the higher education institution of the future as a place where undergraduates would "participate in field projects, relating ideas to real life." Continuing his prolific writing on the subject, Boyer authored The Scholarship of Engagement (1996) in which he argues that academic programs and service (which he terms "the scholarship of engagement") must be combined. All of these calls to action merely mirror the reality in our society.

In 1989, strategic planners at United Way of America foresaw nine societal forces that would have a great impact on our nation's future, most importantly its human and social service system. Obviously these forces will affect higher education (Komives, 1996):

1. Maturation of the U.S. population and its implications.

2. A mosaic society, highly diverse in age, race, culture, and religion. 
3. Redefinition of individual and social roles with service provided by peer groups.

4. An information-based economy in which many people will need to be computer and technically literate.

5. Globalization making the world more interdependent with a need for crosscultural skills and an understanding of international linkages.

6. Personal and environmental health.

7. Economic restructuring with increased competition for shrinking funds and the need for evaluation and outcome assessment.

8. Redefinition of family and home with the growth in needs of nontraditional family arrangements.

9. Rebirth of social activism with citizens involved in seeking solutions to community issues such as crime, the environment, drugs and the need for a realistic education.

These issues are extremely relevant to community colleges, and there is a consensus of opinion that there is a great benefit and need for college students to take part in community service as part of their education ( Cohen and Kinsey, 1994; Weaver, McElhinney and Allen, 1983); however, very little research has been done on the views of students, the impact of their work, and the benefits to the students themselves and to the community. It is the trained college student who in many cases can alleviate the burdens of under-staffing and limited budgets that are the reality that many of our social service agencies deal with on a daily basis.

In the past, colleges were seen as isolated entities apart from the community. Community service is a way for colleges to improve their public image and strengthen 
ties to community agencies (Walker and Nozaki, 1991). These relationships can not only build linkages but also lead to new opportunities in sources of funding that could benefit the community and the college, create career-related experiences for students, and increase civic responsibility on the parts of the undergraduates (Myers-Lipton, 1994). In many cases, students are also isolated. We live in a world of virtual reality and simulated experiences. Economist Jerry Rifkin calls service-learning "an essential antidote to the increasingly isolated world" (1996). It is incumbent upon us as educators to lead the way in this endeavor. If not us, others will take the lead. Possibly, this is why the national government has taken such a keen interest in community service.

Though public service has not been a partisan issue, President Clinton has been credited with much of the recent revival of interest in national service through the National and Community Service Trust Act which was signed into law on September 21, 1993. The Act was specifically designed to engage Americans in addressing the urgent problems facing our nation through direct community service. Learn and Serve America National Service Programs serves as the umbrella organization for the Higher Education Program, Volunteers in Service to America (VISTA), and AmeriCorps was established by George Bush's nonpartisan Commission on National and Community Service. On March 19, 1998, First Lady Hillary Rodham Clinton delivered the President's National and Community Service Amendment Act of 1998 to Congress. In part, she said, “ Serving others and giving back is part of what it means to be an American and part of what it means to be a citizen in a democracy. Extending congressional support for national service into the 21 st century will give millions more Americans the opportunity to serve and strengthen their communities" (National News Service, March 23, 1998). This idea of participation is not a new idea in democracy; it is rather a cornerstone of democracy. It is built on the notion of Greek polis, where the citizen's first priority was to participate in public life. It is this that served as the basis for New England town 
meetings which Thomas Jefferson called the "wisest invention ever devised by man" (1903, vol.8, p.203). It is important to note that John Dewey was a product of that New England environment. Our lives are affected on a daily basis by public decisions. Therefore, we should clearly see the necessity of having an integrated public and private life.

\section{Part Three: Service-Learning in Higher Education}

According to Jefferson, a democratic citizenry should be well educated and informed on the issues of the day with the skills necessary to participate. Early American colleges taught responsible citizenship by educating gentlemen who would be future leaders of this new nation. With the Industrial Revolution, however, more emphasis in education was placed on preparing people with the skills necessary for industrial production to which citizenship took a back seat. Nevertheless, colleges never forgot their mission:

At its best, the campus is expected to bring together the views and experiences of all its points of view and create something greater than the sum, offering the prospect that personal values will be clarified and the channels of our common life will be deepened and renewed (Boyer and Hechinger, 1981, p.56).

The challenge for higher education, it would seem, is not only to train a professional but also a citizen. It is higher education that can offer the setting, the curriculum, and the community for developing a responsible citizenry that must live in a public world. It is the educator who must develop the future generation of public leaders. The means for doing this is through community and public service, experiential 
education, and the creative thinking skills that form good judgment. "Judgment is the ability to bring principles to particulars without reducing the particulars to simple instances" (Minnich, 1988, p.33). This, obviously, is not a solo activity but a collective process that colleges and universities can provide through curriculum and the opportunities for experiential learning that are made available to students as they learn to live a shared life.

Alexander W. Astin reports in a study from UCLA's Higher Education Research Institute (HERI) that "participating in volunteer service work during college has a number of positive effects on students' post-college development including participating in community action programs, helping others in difficulty, promoting racial harmony, participating in programs regarding the environment, and developing a meaningful philosophy of life" (HERI, 1996). Astin takes these results as proof that learning and personal development during the undergraduate years occur as a result of students engaging in both academic and non-academic activities both inside and outside the classroom (Astin, 1993). Students who spend more effort in a variety of activities benefit the most intellectually and in personal development (Astin, 1993; Chickering and Reisser, 1993; Pascarella and Terenzini, 1991). A valued outcome of this type of postsecondary education includes cognitive complexity in which the student develops critical thinking, intellectual flexibility, and reflective judgment. This can be achieved by college administrations that support and finance service-learning, student affairs administrators who support in-class and out-of-class learning experiences and communicate with faculty, faculty who implement experiential learning and so structure curriculum and communicate with other institutional entities, and students who take responsibility for their education and clearly see the relationship of their academic studies and community service.

This does not mean that there are no problems in developing such a program at a 
college. Firstly, there is a need to evaluate such programs and assess student outcomes (Nettles, 1995). Secondly, service-learning programs must compete for meager funds for program implementation, office space, personnel, and equipment (Benjamin, Carroll, Jacobi, Shires and Krop, 1993). A number of studies that offer models have been published (Astin, 1995; Cohen and Kinsey, 1994; Giles and Eyler, 1994, Markus, Howard and King; Myers-Lipton, 1994), but the methods are usually site-specific and not replicable in other settings which unsettles quantitative researchers and their studies. High hopes can easily be dashed when trying to replicate methods and measures. It is for this reason that there is a dire need for qualitative studies such as ethnographies and naturalistic evaluation as supported by Ostrow (1994); Patton (1987); and Rossi (1994). Qualitative studies could yield abundant, vivid data. We are dealing with the impact of a mode of learning on students who are very much individuals; therefore, the impact of such an experience is bound to be non-generalizable and highly personal and diverse, charged with feeling and emotion and, most importantly, with a story to tell. How can quantitative methods and measurements accurately interpret this? Frankly, there are those in the higher educational community trained in traditional modes who may reject qualitative studies as irrelevant, incomplete or not generalizable, but this is not the case. It is time for funders and policymakers to realize that there are pitfalls in so-called "hard data" and that qualitative studies are viable and in many cases desirable in ferreting out information that might be glossed over or lost in typical statistical studies. Other disciplines, such as medicine and law, have used case studies quite successfully for many years.

Another problem is that with all of the negative issues facing higher education and its accountability, service-learning is being seen as a panacea. The published works of advocates make it seem so positive that its detractors are calling for proof in the form of empirical data. Also, it is difficult to find published works by critics. There is so 
much government support and educational praise that we are not responding to the concerns of this faction which may include a majority of faculty who are uncomfortable with the interface between experiential learning and academic learning. Many fear losing control of the curriculum and not being in charge of the students' out-of-class experiences, and many object to the enormous work-load involved (Gore and Nelson, 1984). Faculty members stuck in traditional modes of learning resort to the question: Is it academic?

Recent studies cited in the Michigan Journal of Community Service Learning have found that faculty who participate in service-learning do see a clear connection between academics and community service. Chris Hammond (1994) surveyed faculty at 23 Michigan colleges and universities regarding their involvement in service-learning and their satisfaction. Usable responses were received from 130 faculty members who voiced positive feelings regarding autonomy and perceived effectiveness with students. It is a shame that no such studies have been done with community college faculty nor students at community colleges. In the same volume, Tim Stanton reported on providing an instructional seminar on service-learning for faculty and administrators. He interviewed 12 individuals who had attended a Campus Compact Institute and did follow-up a year later and found that nine had successfully implemented service-learning in their courses, and six of these aided other instructors in implementing service-learning in their courses (pp.7-20). It seems clear that administrative support of faculty attendance at such seminars is necessary to win faculty support for new and innovative programs such as service-learning.

One of the major problems dealing with service-learning in higher education, according to Marilyn Smith, is that there is a total lack of consensus regarding goals. In a case study she conducted of one campus, Smith investigated the goals of various participants in service-learning programs. She focused on intended student outcomes 
based on the perceptions of national policy-makers, national organizations, college administrators, campus community service directors, and student leaders in service programs. The highest priority for national leaders and national organizations was citizenship outcomes. This priority was scarcely spoken of by faculty, college administration, community service staff or students. In particular, students she spoke with saw no connection between service and good citizenship. Smith concluded that there is a need for better communication with campus participants in clearly defining goals and forming links (pp.37-43). Yet a study conducted by the Higher Education Research Institute (HERI) at the University of California, Los Angeles (UCLA) in 199596 evaluated the Corporation for National Service's Learn and Serve America Higher Education (LSAHE) program in relation to the impact of service-learning on three general areas of student development including civic responsibility (good citizenship). Data collected from 3,450 respondents (students attending 42 institutions with LSAHE programs) found that the effects of service were most noticeable in the area of civic responsibility. More than twice as many service participants as nonparticipants $(60 \%$ versus $28 \%$ ) reported on the follow-up to this quantitative study (applying multivariate analysis) that their "commitment to serving the community was either stronger or much stronger" than before (Sax and Astin, 1997). Evidently, this study's findings are contradictory to the findings from the Smith study. Yet, there has been no call for clarification regarding the opposing results in this quantitative research or the many other contradictory findings from the service-learning community. This is, obviously, the politically correct response. Silence. But, how are these findings to be utilized? There is also a need for all parties involved to enter into dialogue on equal footing. In too many instances, politicians and educational administrators are calling the shots while student voices are hushed and faculty concerns are left unanswered.

The service-learning network sheds light on the fact that not all service-learning 
advocates are in agreement on many issues facing service-learning in higher education, as well. Many of these educators express discomfort with movements toward a "best" approach or what books best serve the interests of service-learning. As one such person, Dr. David Lempert, said, "I thought we were about creating the most diverse approach to meet the greatest variety of needs in the most informed way... with learning as our most fundamental goal and developing active, responsible citizens who can think independently" (Service-learning network, e-mail, March 26, 1998 from $<$ lemp@gwis2.circ.gwu.edu>). His opinion that there are certain fashionable "gurus" and that a hierarchy is being established of people who perceive themselves to be leaders in the movement is a healthy sign of the need for debate and discussion in this comparatively new approach to learning. There is disagreement as to whether too many models of service are in actuality service-learning or servitude for credit. There is still a great deal of confusion about the essential difference between internships, capstone experiences, practica, and service-learning, as well as the role of empowering students. These issues need to be discussed and resolved if service-learning is ever to establish an environment in which students can be taken seriously and be allowed to grow and develop in a natural manner, which is the promise of service-learning. "Service combined with learning, adds value to each and transforms both" (Honnet and Poulsen, 1989). It will take a great deal of effort to make such quotes more than mere words that, like political slogans, sound nice but ring hollow.

Harry C. Boyte, the director of project Public Life in Minneapolis, writes in an article for the Phi Delta Kappan (1991) that a major problem facing service-learning is that it was touted as a remedy for college students' lack of interest in all things political but has not been instrumental in engaging students in political activities and public affairs. Youth seem angry about the "foot-dragging" attitude of much of the adult population yet not very willing to do much about it themselves. For this reason, I feel, it 
is very important that colleges include the students in the planning of whatever servicelearning initiatives they develop. We have to put the ownership of problem-solving projects into the hands of our students and give them all the necessary support in creating a successful and positive educational experience. We also must understand, as Kendall (1990) notes, that service-learning programs engage in a diversity of learning goals: cognitive, civic, ethical, and cross-cultural. Clearly, different programs may stress a variety of combinations of these goals. The very nature of experiential learning negates a definitive list of aspects. Viewed from this angle, service-learning can be seen, as Rama and Zlotkowski (1996) point out, as an activity located between two poles that have already been identified:

Figure 2.1

\section{The Service-Learning Continuum}

community service $\begin{gathered}\text { discipline-based } \\ \text { experiential education }\end{gathered}$

service-learning

Diverse approaches are being designed at many colleges and universities throughout the United States that are admirable. The University of Utah, for example, offers 57 courses in 35 majors that require two to three hours of service per week (Groennings, 1997). It is estimated that over 9,000 students have done some form of service with approximately 50 community agencies (Groennings, 1997). At Florida State University, students contribute thousands of hours in soup kitchens, nursing homes and hospitals. Others tutor reading in literacy programs and assist in health care. Many assist migrant laborers through Project Amistades by helping with English language needs. A new Center for Civic Education and Service is responsible for placing students, 
supporting faculty needs and maintaining transcripts of students' service records. The president of FSU, D'Alemberte, writes that service will "improve instruction, enrich the education of students, make the students more desirable to prospective employers, and make the community a better place to live.... Connecting with different sectors of our society builds trust and teaches civic responsibility" (1996, p.2). Service-learning can put students in touch with what it means to be fully human. It can also impress upon faculty the transformative power of their work. Both students and instructors can more clearly see their experiences as meaningful. This is the challenge we face: to make education meaningful for all participants. Service-learning is not the only way to accomplish this, but it is one way. In the studies that have been conducted on college undergraduates, researchers have verified claims that students who participate in service-learning demonstrate more positive effects on psychological, social, and cognitive development (Batchelder, 1994). Although many service programs have different goals, most studies have focused on moral, ethical, social, attitudinal, and personal development outcomes (Giles and Eyler, 1994; Markus et al., 1993). In many studies, such as the one by Boss (1994) at the University of Rhode Island, a significant increase was found in students' moral reasoning ability. How significant are these quantitative studies? We'll never know until the students' voices are heard. The voices that can reflect the actual benefits of service-learning as a valid paradigm.

Figure 2.2 clearly identifies the theory-based studies that have been done related to service-learning. It is evident that not only are more studies needed, but there is a noticeable lack of qualitative research.

Specifically, community colleges enroll $49 \%$ of first time freshmen college students (AACC, 1996). According to the same article, $75 \%$ of community colleges are either actively engaged in service-learning or desirous of implementing such programs. However, the literature does not attest to this fact since very little has been published 
about programs at community colleges. When Campus Compact brought together the Integrating Service with Academic Study (ISAS) Advisory Committee at the Ford Foundation in New York City on December 18, 1995, community colleges were not invited, nor did the discussion even take community colleges into account.

The American Association of Community Colleges (AACC) introduced its service-learning project with the support of the Corporation for National and Community Service in 1994, "to strengthen the service-learning infrastructure within and across community colleges, and to help train faculty members in skills needed to develop effective service-learning opportunities" (AACC Service-Learning Home Page, 1996). This statement was very necessary because the assessment of institutional effectiveness for community colleges must use different indices of success than those developed to assess programs at four-year colleges and universities (Berson, 1998). One such significant difference between community college students and those who attend universities is that community college students can be considered successful without ever receiving a degree from the community college since obtaining employment is seen as a measure of success, as is improving job skills. Many of the leaders (and authors) in the field of service-learning are university based and have nothing but disdain for using service as a vehicle for training students for employment, but as Dr. Arthur Levine, President of Teacher's College of Columbia University said, "College students today want a relationship with their campus much like the ones they enjoy with their bank and their supermarket." They want to get in, get what they need to get a job, and get out. As educators in community colleges, our task is to make that experience as meaningful as possible for these non-traditional students. I feel that service-learning can help in this endeavor since it clearly demonstrates to the student the positive connection between the classroom and the practical application of academic studies to the everyday world in which the student lives. This current analogy of the student as consumer is well-suited to 
service-learning.

There is now a good deal of research evidence to suggest that the more time and effort students invest in the learning process and the more intensely they engage in their own education, the greater will be their own growth and achievement, their satisfaction with their educational experiences, and their persistence in college, and the more likely they are to continue their learning.... While one can ask what a chemist knows, for example, one is not involved in that knowledge until one does what a chemist does (National Institute of Education, 1984, October, pp. 17 \& 28).

As such, service-learning being an active mode of education necessitates that students be inquirers who create their knowledge rather than absorb it. Clearly, students are more apt to acquire content in a discipline if they are closely interacting with it. This leads to application of classroom theory to everyday situations in which students find themselves and other people in their communities. While applying these skills, students are getting more practical experience in writing and thinking. They are out in the community honing citizenship skills and cross-cultural awareness. If we continue with the analogy of the student as smart consumer, she is actually getting more for each tuition dollar than she would get in the traditional classroom. Evidently, this will lead to better access to opportunity as companies and corporations seek a skilled labor force. Moreover, this is a valid way for institutions of higher education to impress the community at a time when accountability is based on graduating students who are responsible citizens and well-prepared to enter the workforce. For these reasons, servicelearning should not be viewed as a bothersome add-on to an already overburdened curriculum, but rather as a necessary partner to classroom instruction in achieving quality educational goals.

As part of its mission statement, Broward Community College is committed to the 
concept of active citizenship and participation in improving community life. Therefore, the college realizes the value of community service and supports reflective activities in the classroom as an integral part of each student's educational experience. The mission statement goes on to say, "to provide the opportunity for students to contribute to the well-being of others through student service-learning programs as part of their higher education experience" (BCC 1997-98 Catalog).

Long before service-learning was institutionalized, student service organizations took part in community projects such as Toys for Tots and homeless food programs. The idea for a formalized service-learning initiative began in 1982 when the Division for Student Affairs set up pilot programs with partial funding from the U.S. Department of Education Fund for the Improvement of Postsecondary Education (FIPSE). So began such programs as Challenge to Youth, in which college students were matched with firsttime juvenile offenders; Transitional Insights Program, which paired BCC students with high school seniors with learning disabilities in hopes of helping prepare these disabled students to enter college. By 1994, the BCC Community Connection was instituted to serve as the umbrella organization to coordinate all service opportunities and to support faculty needs in incorporating service into the curriculum. E. Justine Appelbaum, the college's first director of this office was instrumental in making service-learning visible at $\mathrm{BCC}$ and also in implementing a co-curricular transcript to document service activities.

This is where we currently stand. There is a much greater need for faculty contact and training, encouragement for student participation and student understanding the concept of service-learning, and for administrative support and funding if we ever hope to make service-learning an integral component of our college programs. With the public concern for the "back to basics" movement, constant threats of cutbacks in financial aid and student services, and increased costs of higher education for the student and the taxpayer, service-learning needs to be recognized as a viable alternative that can make 
education work by making education applicable to societal needs. For too long, educators have accepted the notion that some professions: medicine, architecture, clinical psychology, theater and dance, to name a few, are accepted as applied fields and, therefore, include some form of experiential education, such as service-learning, as preparation for the profession; whereas, other disciplines like history, business, and economics rarely expose their students to the experiences of professions in those majors in our contemporary society. We must adapt to the idea that all of the liberal arts need an infusion of experience that is well supervised and designed into the curriculum and institutionalized as part of the culture of the college. There is a great need for articulation and commitment in place of rhetoric. This will be evident in the way administration formulates policy and the institutional approach to education, in the way faculty approach their teaching responsibilities and formulate curriculum, and, most importantly, what and how students learn, apply what they learn, and how they view their learning experience using service-learning. 
Figure 2.2

\section{Qverview of Related Theoretical Research with Undergraduates Related to Service-Learning and Experiential Education}

RESEARCHER POPULATION

Astin, 1996

Batchelder \&

Root, 1994

Boss, 1994
Undergraduate students who participated in service at 41 Learn and Serve Higher Education grantee institutions. $(n=3,400)$

Students in various courses at a small, Midwestern, liberal arts college. $(n=71)$

Students enrolled in two sections of ethics at the University of Rhode Island. $(\mathrm{n}=71)$
PURPOSE

A study by RAND and UCLA on the effects of participation in service on college students on 35 dimensions.

Used an experimental design to evaluate the effect of servicelearning courses on the cognitive, moral and ego development of the students.

Used an experimental design to test the effect of a 20 -hour community service requirement on moral reasoning.

\section{FINDINGS}

Participation in service resulted in higher levels of academic achievement, civic responsibility and like skills.

Participation in service-learning facilitated student development in thinking about social problems, prosocial decision-making, prosocial reasoning, and their tendency to reflect on occupational identity issues.

The section that engaged in community service work and participated in discussions of relevant moral dilemmas improved in their moral reasoning ability. 


\section{RESEARCHER POPULATION}

Cohen \& Kinsey, 1994

Giles \& Eyler, 1994 Students enrolled in a required 1 -credit community service laboratory at Vanderbilt University. $(n=72)$

Hudson, W.E., 1996 Students enrolled in American Public Policy and a European politics course at Providence College. $(n=51)$

Kendrick, 1996

\section{Students enrolled in Mass} Communication and Society, a lecture course at a residential research university. $(n=220)$
Students enrolled in Sociology I at SUNY Cortland. $(n=123)$
To determine the value of service-education projects at numerous sites terms of general education goals and curriculum specific goals.

To determine whether a required 24 -hour servicelearning experience can have am impact on measures of social responsibility.

Used an experimental design to determine differences in belief orientations or attitudes as a result of participation in a course with service-learning.

To examine the effects on two sections of the same course, one with a 20-hour service requirement.

\section{FINDINGS}

Service education, as a pedagogical tool, increased motivation and contextual understanding of specific, substantive course material involving messages and audiences, and students found the project was more useful than other types of assignments.

Students showed a significant increase the belief that people can make a difference, increased commitment to continue doing community service, and reported changes in their perception of the clients.

No significant difference was found in student belief orientations or attitudes between two courses. However the design did not isolate the potential impact of the service-learning component.

Students in the service section showed increased social responsibility and personal efficacy, and greater ability to apply course concepts to new situations. 


\section{RESEARCHER POPULATION}

Marcus, Howard, \& King, 1993

Miller, 1994

$\varkappa$

Robinson, 1975 Community college students enrolled in a social science course. $(n=100)$

Serow, 1990

Students enrolled in a lecture course at the

University students in two $(\mathrm{n}=35)$
Contemporary Political Issues, University of Michigan. $(n=89)$ advanced Psychology courses at the University of Michigan

To examine the effects of an optional linkage between a traditional Psychology course and a community servicelearning course.

To examine the effects of a 1 -credit community service laboratory attached to a 3 -credit social science course on student satisfaction.

A study of the effect of community service on student values.

\section{FINDINGS}

Students reported that they had performed up to their potential in the course, learned to apply course principles to new situations, and developed a greater awareness of social problems.

Students who selected a servicelearning option rated it as significantly more valuable and reported enhanced ability to apply course concepts outside the classroom.

Participation in an innovative community service-oriented curriculum was far more satisfying than participation in the traditional curriculum.

Current efforts to encourage community service should acknowledge the role that values play in pro-social behavior. 
Chapter III

Methodology

Chapter III of this study presents the rationale for the specific methodology chosen and the critical elements necessary to conduct such a study. Part One deals with the underlying assumptions of a qualitative interview study. Presenting these assumptions helps guide the reader to better understand the reasons for choosing the specific methodology used in this study and, hopefully, address any concerns the reader may have. Part Two identifies the sample and information pertinent to the sample in an interview study. In Part Three, the design is discussed including the criteria for validity and dependability. Then Part Four details how the data was analyzed. Part Five focuses on the role of the researcher in an interview study. Finally, Part Six describes the pilot study.

Part One: Underlying Assumptions

Try as we might, we can never see with any eyes except our own.

Justice Benjamin Cardozo

It is necessary for qualitative researchers to acknowledge those areas in their research studies that cannot be objective. Eisner(1991) tells about subjects who may expect to be flattered and are not happy with any negative information reported in a research study. To delete any negative findings merely to appease certain subjects, or in this specific case supporters of service-learning (and I am one of them), would be to 
"engage in a public relations campaign" and not in an ethical qualitative study.

Eisner goes on to talk about the fallacy of a researcher being "neutral" which he sees as an idea that is inherently flawed. Even in a descriptive study, there can be no neutrality since the researcher determines what will be described. In 1992, Eisner published an article, "Objectivity in Educational Research", in Curriculum Inquiry, in which he attempted to persuade readers that both ontological and procedural objectivity were less than workable. The concept of objectivity is usually meant to mean being impartial, open to all possible sides of a debate. Through this process, we gain knowledge. Ontological objectivity deals with the way things really are in their pristine state. Procedural objectivity seeks to abolish individual judgment. Instead, he presented Dewey's thinking on the subject. Specifically, whatever we believe we know is a function of a "transaction" between the qualities of the world that we cannot know in their pure form and our own perceptions based on our life experiences. Many might argue with this view as being senseless relativism, but few can argue with the supposition that "knowledge is always constructed relative to a framework, a form of representation, and to a personal biography" (p.13). In essence, there is no one way to find meaning in the world. This is very pertinent to qualitative studies that seek different ways to interpret a lived experience and invite people to take part in what is a plurality of views. Eisner quotes Stephen Toulmin, a leading philosopher of science, as saying, "All of our scientific explanations and critical readings start from, embody, and imply some interpretive standpoint, conceptual framework, or theoretical perspective. The relevance and adequacy of our explanations can never be demonstrated with Platonic rigor or geometric necessity...." (p.15). Obviously, Toulmin is telling us that what we believe, as long as it is grounded by good reason, is a realistic goal for inquiry. Now that I have informed the reader and myself of the reality of bias and fallacy of neutrality and objectivity in a study, I can proceed with my investigation with the understanding that it is my responsibility to 
seek knowledge through the reported discourse of all participants in this study as we inter-relate, interpret, and negotiate the meaning of a service-learning experience, and, in the end, the interpretation is mine. As Jean Piaget said when completing his work, The Various Forms of Knowledge, “... I put forward nothing except possible interpretations based on facts" (Gruber \& Voneche, p. 859). In addition, Roy A. Rappaport reminds us, "Without the interpretive tradition, the scientific tradition that grounds us will never get off the ground" (Wolcott,1995). Furthermore, Bogdan and Biklen (1982) write, "people act, not on the basis of predetermined responses to predefined objects, but rather as interpreting, defining, symbolic animals whose behavior can only be understood by having the researcher enter into the defining process" (p.38). Attinasi (1992) advised use of "phenomenological interviews" through which the researcher gains access to the meanings people attach to their own unique life experiences using a semistructured interview schedule. This study sought those meaningful relations that needed to be interpreted and, hopefully, lead to knowledge that will enhance our understanding of students' perceptions of a service-learning experience at the community college level.

\author{
Part Two: Sample
}

Somehow we have lost the human and passionate element of research... For too long we have allowed psychometrics to rule our research and thus to decontextualize individuals.

Valerie J. Janesick (Denzin \& Lincoln, pp.209-219)

In this study I interviewed five students who were selected according to purposive sampling since I constructed a non-representative sample with the intent of sharing each participant's story relating to her/his service-learning experience and making key comparisons and testing and developing theoretical propositions. This approach has a 
long and valuable history in the field of psychology where if the goal is to procure general knowledge, the focal point would be a few intensive cases. Such was the manner in which Freud added to the general knowledge of, for example, pathology and personality. His work was always concerned with the "Ich", in English the "I", first person singular (Boorstin, 1983). It is hoped that this emphasis on quality rather than quantity will make it possible to explore in detail the relationship of the participant and the meaning she/he brings to the situation under study. Sampling is a very important element in qualitative research. Peter Reason poses one of the main questions of inquiry through participation as: "Who owns the knowledge, and thus who can define the reality?" (Denzin \& Lincoln, p. 263,1998). Reason is clearly showing us that the participant possesses the knowledge. This builds on the words of Paulo Freire: "For me, the concrete reality is something more than isolated facts...but also includes the ways in which the people involved with these facts perceive them...the connection between subjectivity and objectivity" (Denzin \& Lincoln, p.278-9,1998). In its long history, this in turn builds on the work of John Dewey, who as early as 1929, argued against the traditional disunion between knowledge and action. The focus here is on active research not static. This is a living process, not a formal academic one. Without it, we end up with a deafening silence. Therefore, it is imperative that we hear from those students who have experienced service-learning. For these reasons, I employed purposive sampling in this study. I interviewed five students (every fiftieth student) from a list of 253 students, since this was as convenient and valid as any other manner of making a selection of students who have experienced service-learning as part of a class at Broward Community College (BCC), Central Campus. BCC is typical of many community colleges in an urban growth area in that the majority of its students are non-traditional in age and ethnicity. The college has also been experiencing a high attrition rate among its students and is actively seeking alternative methods to counteract this phenomenon. The students 
who were selected agreed to be interviewed. The interviews took place during the fall semester of 1998. I first telephoned each selected student to speak directly with her/him, briefly explained the study and why it was important for her/him to take part in this study and requested the student's cooperation. I told each student to expect an informed consent letter (Appendix A) in the mail within two days, explained what informed consent was and how it protects them and me, as well, and requested that they respond within five days, so that we, together, could schedule the time, place, and dates of the interview sessions. Each student was interviewed on three separate occasions. Ongoing analysis of the interviews was conducted during this same period of time. To validate all information, at the end of the interview process, each respondent received a letter summarizing the findings and was asked to comment in writing on the validity of the information from our interview sessions including whether the work was "true" of herself or himself. A character in John Steinbeck's East of Eden, which I read with a class during the spring semester (1998) says, "No story has power, nor will it last, unless we feel in ourselves that it is true, and true of us." It is very important that the participants for this study, as Seidman (1991) strongly advises, keep the interview as their own "meaning-making process". Eisner (1992) believes that this information should be shared with the appropriate people before it is made public and that their responses should be sought; however, in the final analysis, it is the researcher who determines what will be included in the study and how it will be interpreted since once the participants are given the right to negate any of the information, the intellectual integrity of the researcher is compromised. In addition, Janesick (1998) points out ways of making the very intricate and challenging act of interviewing another person, while respecting the dignity of that person, as non-intimidating yet as structured as is possible. This, she shares with us, is accomplished through the interviewer being well prepared and framing questions based on Spradley's model. As a result, the interviewee will know what is expected of 
her/him and be willing to share experiences from her/his own perspective in her/his own words. As Janesick reminds us in her highly perceptive work, "Stretching" Exercises for Qualitative Researchers: "Interviewing is a meeting of two persons to exchange information and ideas through questions and responses, resulting in communication and joint construction of meaning about a particular topic" $(1998$, p.30). The researcher must always remember that the interview is an act of communication in which both parties play a valuable role. These two people are of equal importance to the process and share responsibilities central to the interview procedure in order for it to eventually provide information that is valuable as it relates to a given topic.

At the same time, it is important to remember, as Kvale tells us, that "the ideal interview subject does not exist," and that some interviewees are better than others (1996, p.146). A more in-depth description is provided by Spradley (1979) who shares five minimal requirements for selecting a good informant: 1) thorough enculturation, 2) current involvement, 3) an unfamiliar cultural scene, 4) adequate time, and 5) nonanalytic. He tells about the experience of Elizabeth Marshall, a young American anthropologist, doing research among the African Bushmen. Marshall, while interviewing Tsetchwe, a woman of the tribe, suddenly realizes, in the manner of a revelation, the nature of ethnography; "Tsetchwe began to teach me" (p.4). To learn from others, to enter their world and to acquire the knowledge that humans make use of in interpreting their unique experiences that engender certain behaviors is what is important. The researcher as student; the respondent as teacher.

Yet, I am left with questions that haunt me. Can such a trusting, open relationship be established between inquirer and respondent that the researcher can really get a complete, honest story? Exactly, what is the nature of the relationship between the researcher and the respondent? Do the interviewees' voices tell us what they truly believe? Do we take a respondent at her/his word? If not, just how far can we explore 
before ethics becomes an issue? It is the quality of these interviews that decide, in the final result, the quality of the analysis, the validity, and the reporting of the results of the entire study.

Part Three: Design

Maintain the needed flexibility of qualitative research design, so that the research can unfold, cascade, roll, and emerge ... but is yet sound.

Lincoln \& Guba (1985, p.210)

This interview study described and explained the perspectives of five community college students who had experienced service-learning as part of one or more of their college courses at BCC, Central. The data was collected during three interviews with each of the informants. The first interview session served as an icebreaker, an exploratory interview that was open-ended and had little structure. Since I hadn't gained the respondent's confidence as of that time, I asked for permission to tape the session and explained its value to me and the interviewee. The second and third interviews were tape recorded and transcribed for analysis with the subject's knowledge. Each interview was approximately 60-90 minutes in length. During the interviews, the researcher also took notes. The three interviews for each respondent took place over a period of three weeks with each interview being approximately one week apart.

The purpose of the interviews was to describe and explain the perspectives of each of the respondents as they formally and informally answered structured, semistructured, and unstructured questions. Hopefully this will help to define what the 
researcher sought to understand in conducting this specific study, so that the research questions are more than adequately answered to add to the knowledge in this area of service-learning. These focused, in-depth interviews are informed by assumptions taken from the work of Alfred Schutz as reported on by I.E. Seidman (1991).

In this approach interviewers use, primarily, open-ended questions. Their major task is to build upon and explore their participants' responses to those questions. The goal is to have the participant reconstruct his or her experience within the topic under study (p.9).

The first interview gives the interviewer and interviewee time to get comfortable with each other and understand the nature of the interview setting and expectations, to establish a relationship. This briefing sets the context of the respondent's experience through grand tour questions and gives the researcher the chance to determine if the interviewee will make a cooperative respondent. The second interview will be more detailed since, at this point, the interviewer will use questions (structured and semistructured) to elicit specifics about the context of the experience (Appendix D, Interview Protocol). As Valerie J. Janesick informs us, "qualitative research design begins with a question" (Denzin and Lincoln, p.210). It is during this second interview that a majority of the data was collected. It is important, the Jungian therapist Hillman says, that both the interviewer and interviewee make room for the "inter" since the "you" and the "me" can impede the true essence of what is being said. It is not our opinions that count, he tells us, it's the "inter" (Kvale, 1996). During the third interview, the respondent was encouraged to reflect on responses given at the second interview and clarified any concerns the interviewer may have had from transcribing and analyzing the information and the respondent may have had of the interviewer. This third interview session culminated with a debriefing. Though meaning is important throughout the entire process, it is during the third interview that it becomes of central importance. The 
meaning that emerged from the context of this specific study was the appropriate extent of generalization that could be expected from qualitative research (Lincoln and Guba, 1985). This study did not specifically seek to attain generalizable results. The purpose was, rather, to engender an accurate and trustworthy account of the perceptions and experiences of the participants themselves. Therefore, I must reiterate, there was no attempt to relate the results of this study for the purpose of generalizations; though, it is hoped that the detail was sufficient enough so that others attempting similar studies would find the information presented to be valuable, and its results would further encourage others to do research related to students' experiences and perspectives of service-learning.

While the research design suggested here offers a fair amount of flexibility within a structured format, Lincoln and Guba (1985) strongly recommend that the researcher establish credibility in the study. Lincoln and Guba (1985) refer to this as the "truth value" of the study (p.290). They go on to say that the strength of the study and the amount of data that clearly demonstrates the complex interactions and variables attest to its validity. In a postmodern context, validity is concerned with the degree that a method investigates what it sets out to investigate; more specifically, the variables that are of interest to the researcher. Kvale (199) relates that if this is accomplished, the research can be said to lead to trustworthy scientific knowledge. This rests on the classical criteria for truth: correspondence which refers to whether a knowledge statement corresponds to the objective world, coherence which refers to the consistency of the statement, and the pragmatic which relates the authenticity of the knowledge statement to its practical results. In the interview situation, it is the communication of knowledge that is important and the checking, questioning, and theorizing of that knowledge. This, in some way, attempts to clarify the disturbing area of validity by accepting the traditional research paradigm. If we don't, it leads to a debate without end because who will 
stipulate the meaning of validity? Based on whose code of ethics? Is validity a social construct? Is it better negotiated for each individual study between researcher and participant(s)? Is the reader at all involved in the issue of validity? Whatever conclusions we come to, the results of the communication between the inquirer and respondent should as truthfully as possible represent the beliefs of the respondents as interpreted by the researcher. As stated before, the results of each respondent's interview sessions was discussed with her/him to check for accuracy.

Part Four: Data Analysis

Do not let the analysis stage inflate so that it consumes the major portion of time available for an interview project. The analysis of an interview is interspersed between the initial story told by the interviewee to the researcher and the final story told by the researcher to an audience.

$$
\text { Steinar Kvale (1996, p.184) }
$$

In an interview study such as this, the perspectives of the interviewees may have little meaning by the presentation of the data alone. It is the analysis of this data that, in many instances gives rich meaning and clear understanding to their statements and emotion. Both Kvale and Spradley tell us that there is no magic key nor any one single method to analyzing the data. Instead, there are various methods which the researcher must investigate to find the ones suitable to a specific study and its type and purpose. It also depends on what method or methods the investigator feels comfortable with (Miles \& Huberman, 1994; Wolcott, 1994). Analysis is the looking for meaning and relationships in the data. Kvale tells us that this begins when the respondents themselves 
see new meaning and different connections in what they say as they tell their stories and reflect on what they have said, without the researcher defining anything that has been said. The next step involves the researcher interpreting statements made by the respondent, rephrasing them so that the interviewee has the chance to comment on the accuracy of the statements as the interviewer understands them. This Kvale calls a "selfcorrecting" interview (p.189). In the next step, the researcher interprets the transcribed interview, extracting superfluous and redundant information, seeking clarity and categories, working out structures and relations of meaning. It is then that the respondent's voice is heard with his/her own unique understanding of the meaning. One of the more recent forms of analysis that is being widely used, Kvale relates, is ad hoc analysis based on no one standard method to interpret the entire interview but rather an interplay of styles that include noting patterns and themes, making metaphors, making contrasts and comparisons, noting relationships among variables, and, in the end, building evidence and making conceptual coherence of the information. Janesick tells us that it is this componential analysis that can aid the researcher in answering the contentious question that all researchers face: "Can I capture and recreate the power of lived experiences within this given social context?" $(1998$, p. 122). The response can be found in this holistic approach to analysis. After all, human interactions are very complex to unravel. Spradley refers to componential analysis as the "systematic search for the attributes (components of meaning) associated with cultural symbols" (p.174). When data is organized into categories, it is essential to utilize the meanings of the interviewees. There are two parts to componential analysis. The first addresses the categorization of data for meaning, and the second addresses the organization of questions to be used in interviews with the respondents.

Since the readers of an interview study do not have access to the entire transcripts, control becomes a major issue. Therefore, it is necessary for the researcher to 
explain the procedures in detail and supply a sample of the interview transcript for the readers to see; although, it is quite usual for people to see and interpret the data differently. The question here is not whether people agree with the interpretation of the researcher but whether the reader, if adopting the same viewpoint as the researcher, can clearly understand the researcher's findings. It is not a case of agreeing on the interpretation but understanding how the researcher arrived at his findings.

\section{Part Five: Role of the Researcher}

“...getting nosy."

Harry F. Wolcott (p. 102)

Wolcott, in very plain language, admonishes the researcher to aggressively search for information by "getting nosy." Most other authors in the field do not take as light-hearted approach to the matter. Miles and Huberman (1994) state quite clearly, "It is probably true that, fundamentally, field research is an act of betrayal, no matter how well intentioned or well integrated the researcher" (p.265). Betrayal! That's a rather frightening thought. I'm not looking to get killed by some angry respondent with a score to settle. This sounds more like a John Grisham novel, or a Verdi opera, than an academic study. Like Wolcott, I find this rather disturbing. Sociologist, Maurice Punch, takes the betrayal theme a step further by suggesting that in the process of gaining trust there is "a double betrayal: first by them (the respondents) of you (the interviewer) but then by you of them. Often in fieldwork the participants are conning you until you gain their trust... and then you begin conning them" (1986, pp. 72-73). As an educator, I'm 
not sure I feel comfortable with this cloak and dagger intrigue. I'd rather leave it to someone like Joan Didion who treats her research as detective work and after publication of her book Miami was invited to leave Miami posthaste or find herself being fitted for a pair of cement shoes. I'd rather take the advice of Kvale who, in a more practical manner, describes interviewing as a craft; as such, the researcher has to bring to it sensitivity, empathy, and knowledge. "The craftsmanship and credibility of the researcher becomes essential" (p.241). For the novice researcher, in particular, imposing his values becomes an important issue. It takes a great deal of time, practice, and skill, on the part of the researcher, to minimize such a weakness that seems inherent in qualitative studies (Marshall \& Rossman, 1995). It is important that the researcher clarify ethical concerns for the participants as well. Failure to do so could compromise the findings of a qualitative study. Therefore, it is necessary for the interviewer to develop roles that facilitate receptivity and encourage participation on the part of the respondents. This could also be called building a trusting relationship. The qualitative researcher must assure the participants that their responses will be treated with confidence (Lincoln \& Guba, 1985; Marshall \& Rossman, 1995). Wolcott now suggests that getting nosy intrudes on people's lives and requires a great amount of tact on the part of the interviewer (Is Wolcott having second thoughts about what Miles and Huberman said about betrayal? The plot thickens). Subjects are opening themselves up to scrutiny in a way that is not normal in everyday life. The researcher has to appreciate this and, therefore, extend every courtesy to members of the study. To be an interviewer is a difficult and challenging task; however, it is only through knowledgeable reporting of the lived experiences of individuals that we can begin to appreciate, understand, describe, and explain their perspectives in the hope of gaining insight into issues such as servicelearning and its implications for the community college student from the student's perspective. 
Like many educators at the community college level, I have been very concerned about the weaknesses displayed by a majority of the students in relation to lack of basic skills, skill application, disappointing study habits, unclear understanding of goal setting, lack of respect for self, others and the community, and a general paucity of real power; the kind of power that enables a person to take control of her/his life in comparison to brute force so evident in today's world. How can we combat this? An answer presented to me by my own daughter, who headed the college's service-learning project, was to implement service-learning. By this time, like many of my colleagues, I had become so cynical that I doubted whether there was any positive answer to my query. However, if I were to stay in my current profession, there was no way that I could continue on without seeking some alternative to the current situation, so after attending a workshop on service-learning, doing reading, and having my daughter's support, I adopted service-learning as part of my course curriculum. The results of one particular class's experience with service-learning are presented in Part Six: The Pilot Study. Though I would like to have seen more students take part, the positive impact that service-learning had on a few students who had initially confessed to poor academic habits and negative self image impressed me.

At the time, my feelings were that though I did not realistically expect this approach to work for all students; if it could help even a few, it might be worth the effort. It seemed to me that it could make learning practical, experiential. It brought education more in line with John Dewey's philosophy of participatory democracy which I had always admired. Community colleges, especially in urban areas, are seeing a greater number of minority students, students who perceive themselves to be alienated by "the system"; older students who need to upgrade skills to keep their jobs or advance but haven't been in a classroom in years; women, in the current jargon called "displaced homemakers" who want to and have to make a meaningful life for themselves. These are 
the students who we deal with on a daily basis at a community college, not the traditional college student that most of us instructors have been trained to teach. We tend to teach subjects and not take the human into account. Service-learning, I feel, is concerned with participatory education. Yet, outside of asking students to answer questions, give a presentation, or take part in a group discussion (all graded!), we rarely allow the student to participate in her/his education, to investigate areas of interest to her/him in a discipline. Quite simply put, most of us educators still think about the educational experience in a traditional paradigm that is too comfortable to question. Why bother to change? To combat this traditional mindset, I was eager to investigate what students think and believe about their service-learning experience. From their own point of view, I was eager to see whether a service-learning experience helped them realize the practical nature of education. Has service-learning given them the ability to perform effective actions based on academic knowledge? Will my questioning them result in an infinity of responses and reflections for them and me, as researcher, that will shed light on this issue and help lead to further qualitative research? As Spradley (1979) so aptly put it:

I want to see the world from your point of view. I want to know what you know in the way you know it. I want to understand the meaning of your experience, to walk in your shoes, to feel things as you feel them, to explain things as you explain them. Will you become my teacher and help me understand? (p.34)

The researcher becomes the research instrument. Though both people are participating, it is the researcher who sets the parameters, sets the direction the interview sessions will follow and gleans meaning from all that is said and, just as importantly, unsaid. I am but one educator sharing a classroom with my student-learners, reaching out from that classroom to the world beyond and drawing that world back into the classroom, a rhythmic motion; together we learn; we apply ourselves because we can make a 
difference in our own lives and for the benefit of our community.

My love of art and painting (pictures, not houses!) has trained me to see intensely, to look for patterns, relationships, connections of the part to the whole, and shades of meaning. Interactions in particular settings interpreted through culture, traditions and value systems result in a complex creation in which I look for meaning. Complexity is not a strong point with many Americans who look for fast cures, the right answer, the " a place for everything, and everything in its place" attitude, neat and tidy. But life is very complex and intricate; it cannot be explained easily according to set patterns, the "this or that" mentality.

My love of reading has presented me with a wealth of ideas, different points of view, and, hopefully, familiarity with the literature needed to carry out a responsible qualitative study. Though, I will be the first to admit that I am a neophyte. If a prolific amount of reading has taught me anything, it is that the thoughtful reader, in many instances, reconstructs what the author has imparted to fit her/his own reality. As researcher, I welcome the reader to make my data and interpretations as personally useful as possible. This is as close to generalizeable as my work will come because, you see, it is my work based on a very specific setting with which I am familiar and which I have chosen to investigate. Therefore, I will be dealing with, what Clifford Geertz (1973) termed, "thick description" as opposed to comparative description. Again, readers are welcome to make comparisons as long as they do not devalue the results of this specific phenomenological study. Hopefully, it will contain valuable information and insights that will add to our knowledge of how students perceive a service-learning experience. 


\section{Part Six: The Pilot Study}

The true center of correlation on school subjects is not science, nor literature, nor history, nor geography, but the child's own social activities. The school must represent life - life as real and vital as that which he carries on in the home, in the neighborhood....

John Dewey

It's the dress rehearsal. Taking the show on the road before...Broadway!

Bruce L. Berg

If the researcher is the research instrument, it is necessary to be as expert as possible in the interview process and in human interaction. Learning comes from doing. Therefore, it would only seem logical to do a pilot study in preparation for an in-depth study. This is where the researcher can check for problem areas and take time to reflect on what could be helpful insights. Marshall and Rossman suggest that a pilot study can also lend validity to the researcher's work and build the researcher's confidence in carrying out a study (1995). Obviously, it also provides information for the study and helps the researcher organize a plan of action and helps with working out the details of the management of data. The complexities of the research process are well served by an exploratory venture such as a pilot study.

Prior to submission of the proposal, I proceeded to conduct a pilot study with students in one of my English prep classes at B.C.C. Central during Term I, 1997-98. I announced to the class my intent, invited the coordinator of service-learning to explain the program, answer questions, and address concerns. Very few of the students asked questions or made comments. After she left, I recommended that the students take time to read the information she left with them before the next class session. At the next class 
session, I asked for questions regarding service-learning. Basically, there was a profound silence. Therefore, to get the students to be active, I asked them to compose a list of what they thought might be the positive and negative aspects of service-learning in relation to our class. On the whole, their answers were sketchy, showed little thought, and less interest. I decided it was time to begin by asking for volunteers to take part in this pilot study. Students who agreed to take part would be expected to do 20 hours of service-learning and keep reflective journals. The students who chose not to participate would be expected to read one extra novel and keep a reflective journal. Out of 23 students, eight chose to do service-learning. At the end of the semester, each servicelearning student would take part in one, 1-2 hour interview. During the first ten weeks of the semester, I had the service-learning students form a group for discussion and reflection on their service-learning experiences while the non-service-learning students formed groups to discuss and reflect on the novels they were reading. In the following three weeks, students who did service-learning were asked to join non-service-learning groups to share their experiences with those students who had not taken part in servicelearning. Two students who had taken part in service-learning were especially eager to share their experiences. As the semester progressed, their grades had improved markedly. One of the two had demonstrated very shy behavior at the beginning of the course, but after four weeks of service-learning she was talkative and smiling a good deal of the time. Instead of doing her 20 hours, she logged 44 hours and received a letter of commendation from the agency where she had worked and was offered a part-time job during weekends and vacations. The other student had begun writing very well and applied for an internal scholarship that BCC was offering for which she had to write an essay (an idea that would have paralyzed her at the beginning of the course). She won! She was so excited when she found out that she called me out of a meeting to let me know. These two cases demonstrated to me that service-learning could be a viable 
alternative to traditional forms of learning. It seems that the practical experience that service-learning offers in relating classwork to the everyday world can be beneficial for some students.

What I learned from this pilot experience, however, was that I was too closely involved with these students to be objective. My study would have to deal with students who I did not know before the research was to begin. The pilot study also made me aware of student concerns that I would otherwise not have taken into consideration. Many of the students were concerned about time to do service-learning and adjusting schedules since many of them work besides attending classes. Some of the students needed more information on making a connection between school work and servicelearning, and many did not understand the use of reflection. I decided to look into this and discovered that Kolb's Experiential Learning Model details the fact that not all students find reflection easily accessible, especially if they are not assimilative learners. However, service-learning is attracting more and more accommodative learners because of the practical nature of service-learning and as an alternative to more analytical learning. Therefore, we who offer service-learning must be aware of this and plan for this. Obviously, this is something I will have to take into account when I create questions for my study. I also noticed during my interview sessions in the pilot study that I was not patient enough with students who did not seem to take their service-learning experience seriously. They treated it as a way to get out of reading another book. Instead of remaining even tempered and factual, I openly showed my displeasure. In some cases, I let pauses between responses go on to become uncomfortably long. I should have used follow-up questions to fill in gaps. Another important point concerns the setting, the environment where the interviews take place. I used my office since I can close the door, and I thought that the students would be comfortable since they visit my office during the semester for conferences and small talk. I was wrong. The phone would ring, someone 
would knock, and because of space limitation, I was forced to sit behind a desk which served as a barrier between the interviewee and me. It clearly compounded the discomfort of the interview process for a few of the students. After completing the pilot, I had the chance to stand back and reflect on the whole process and based on that reflection, I have learned a great deal. Dewey raised the question of reflection when he said, "The learner must be actively involved in problem solving through identifying a problem, contemplating a solution, acting upon it and reflecting upon the solution process" (1933). Now, I don't think I would ever get involved in research, that especially includes interview, without first doing a pilot study and taking time to reflect on the process. It serves a planning function by clearly re-creating the past that gives direction to a future goal. The pilot study offers time to write and re-write so that, hopefully, the researcher finds the voice to say what he/she wants to say which can be very difficult. It made me more aware of my senses and presented the opportunity to be cognizant, more observant, of the physical cues, or body language, of respondents. What qualitative researchers call "seeing what is observed." I watched the respondents movements more closely, their eye movements, breathing patterns, hand gestures, posture, to glean meaning from all of this. I listened more carefully to voice tone, speech patterns, choice of vocabulary words. The pilot study offered me the practice and training that I need to feel more self-confident, organized, and prepared to carry out an actual study. This definitely is not an exercise for just the novice; it is invaluable to any researcher. Just as the concert pianist does warming up exercises before each performance for agility in finger movement and acuteness in timing, so should the researcher do a pilot study before embarking on a project. 
Presentation of the Data

In this study, I interviewed five students who attend Broward Community College, Central Campus, and have taken part in a class that has claimed to offer a service-learning component to those students who wish to take advantage of it. The purpose was to see what this experiential education experience meant to each one of them. Each of the participants is treated in a separate section. There are several reasons for this approach. The first is that it is most important to see each respondent as a distinct individual with a unique voice. In too many instances, traditional research has viewed people, such as college students, as one-dimensional subjects all speaking in one voice as members of an isolated sub-culture. While we must recognize and heed any similarities among students who take part in a service-learning experience, it is vital that we explore the individual perspectives that are present, as well. Therefore, it is these individual perspectives that this dissertation sought to describe and explain.

Richard Poirier (1992), claims that [William] James, [John] Dewey, and [Gertrude] Stein in their work heeded Emerson's dictate to make any idea into their own by giving their own unique voice to the idea and actually make it their own since each individual is a unique "work-in-progress" that grows through taking part in contact with others. This is not a phenomenon unique to the worlds of literature, psychology and philosophy. Bogdan and Biklen (1982) tell us that all humans are "interpreting, defining, symbolic animals" whose behavior can only be understood by entering into an interactive relationship with a researcher who enters into the defining process. It is these phenomenological interviews that help gain access to whatever meaning individuals, such as students, give to their experiences. There is a history of using phenomenological 
interviews to determine changes in students that take place during the college years (Freedman,1967; Madison,1969; White,1966), but these studies were conducted approximately thirty years ago with traditional, college-age students (18-22) who do not represent the array of non-traditional students attending college in this last decade of the Twentieth Century; nor were they familiar with the current innovative programs, such as service-learning.

For the purposes of this study, semi-structured interviews were conducted with the five participants during Term I of the 1998-99 school year. Prior to the interviews, students received a letter from the researcher explaining the purpose of the study seeking their cooperation. By informing them in advance, it was hoped that they would take time to reflect on their experiences and be as informative as possible. The first set of interviews took place in a secluded lounge area in the College library. All subsequent interviews took place in the researcher's office at the College and with the consent of the interviewees. All interviews ranged in time from thirty-five minutes to one hour. In addition, all interviews were recorded with the participants' knowledge and transcribed verbatim and discussed with each student to attest to accuracy and, if the interviewee wished, the right to delete or add any information that she or he desired. All of the student participants signed a consent form giving the researcher the right to see, copy, and use material from their journals (Appendix C). When using such material, the researcher has to be very aware of all of the ethical ramifications involved in seeking to honestly report and make sense of another person's words, both verbal and written. (Please see Chapter Three for a presentation of the ethical issues that I considered). For this reason, a close working relationship was established with each respondent which included an almost constant review and discussion of the data. Also, to assure anonymity of the respondents and their right to privacy, I have given them pseudonyms. This will in no way interfere with the reporting of factual data nor will it hinder the reader in seeing 
each respondent as an active participant in this study. After introducing the categories, I will introduce you to the participants themselves so that we can bring their voices out of silence, give them life, and listen to what they have to say. I will then report what I heard, so that you can understand our milieu and you can interpret the data, if you so desire, to apply to your unique setting.

\section{Organization of Categories}

During the process of analyzing the data, nineteen categories emerged from the data. These categories were then examined for potential patterns. This led me to major categories and sub-categories (Figure 4.1) that reflected what seemed to be all relevant aspects of the messages that were shared between the researcher and the participants, retaining the exact wording used in the statements. Hopefully, this criteria of selection eliminated any analysis that might be construed as support material solely for the researcher's point of view (yet another ethical issue). In addition, while the aim of the study was constantly kept in mind, the researcher remained open to any unexpected results that may have emerged from the data. The analysis led to categories that could be

combined and, therefore, to be more generic. Quite obviously, respondents differed in the amount of information they provided for each category and placed more or less emphasis on certain of the categories or aspects of the categories. This should become clear to the reader as the participants' stories unfold. The major categories are Personal Growth, Academic Skills, and Citizenship Skills. 


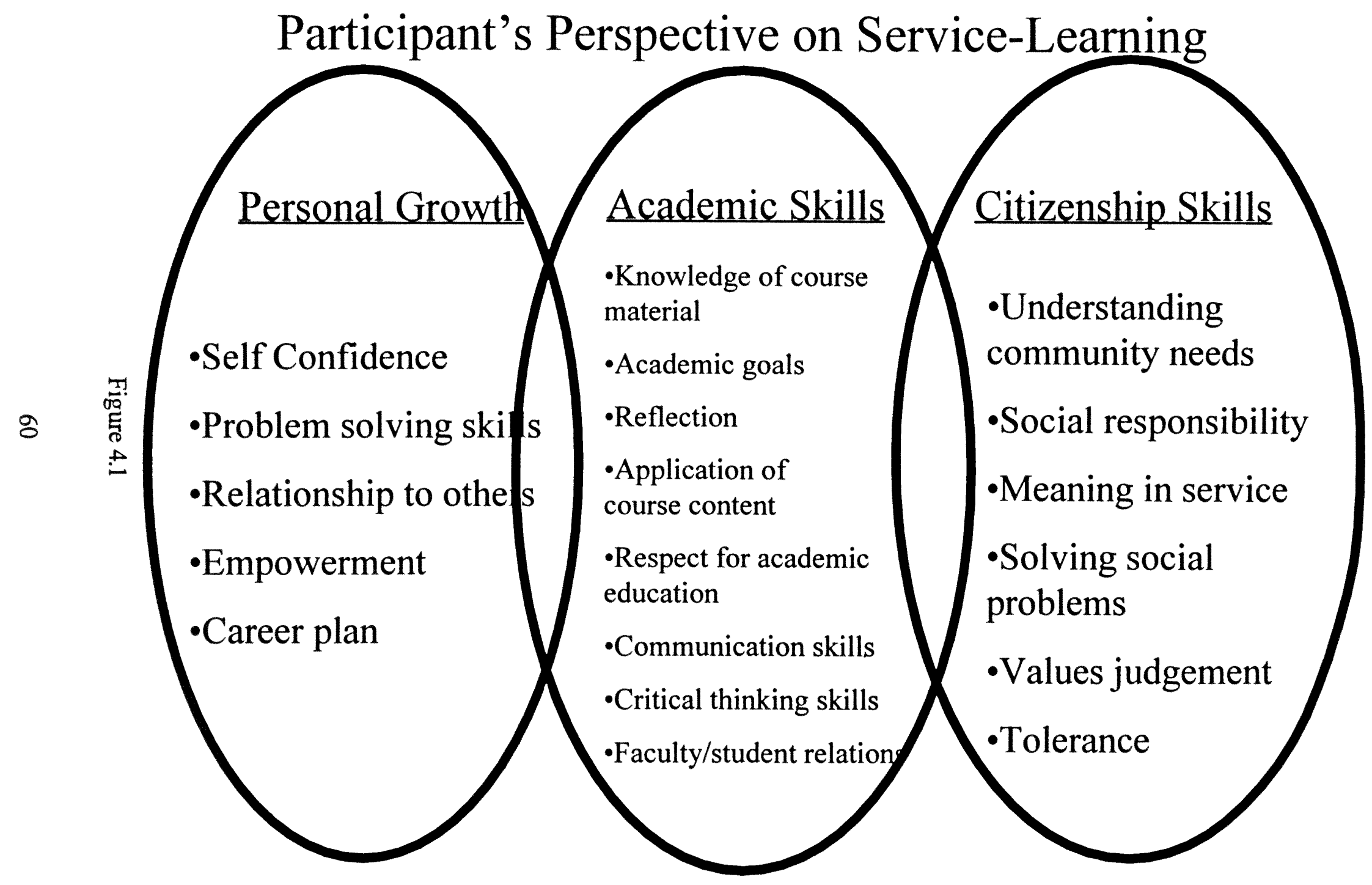




\section{Susan's Perspective}

Susan, who admitted with a shy grin to being "late" thirty something, was born in the countryside of West Virginia and brought up on a farm. She smiles a lot as she speaks and sits tall and straight. The only sign of make-up is a dab of a pale colored lipstick. Her long brown hair with a few gray hairs here and there is knotted in the back.

She strongly identifies with small town, country living and its social codes:

I'm really a country girl at heart. That's where I was born and brought up. Most of the people were kind of poor, but what was important was we didn't know it. Dad worked the farm, and he also worked at a hardware store in town. Mama did so much, and she's still doing it ( with a hearty laugh). She cooks, cleans, mends and darns, gardens, does charity work at church and works at a supermarket out on the state highway. My brothers and I were always expected to help. We were up at five a.m. everyday to help; then, we came in, washed up, dressed for school and ate breakfast before we walked almost a mile to get the bus. We were taught never to swear and to act respectable and treat others that way. I believe in that right up to today, and that's the way my kids are being brought up.

Susan is married to a man who is a custodian for the Broward County

School System. A man she has known since she was a sophomore in high school in West Virginia.

We came here more than fifteen years ago to have a little better life. We are living better, but I don't think it's a better life. Crime and gangs. I worry for my kids all the time.

Susan and her husband have two children who are both in elementary 
school. When the children started school, Susan decided that she wanted to attend college, a dream she long harbored after having dropped out of a practical nursing course years ago to marry and start a family. Broward Community College was the logical choice since it was located in the community and would not disrupt the family lifestyle. In addition to that, it was much cheaper than a four-year college or university.

I feel comfortable here. The campus is small and so are class sizes. I wouldn't be comfortable at a big school. It would make me uneasy. I like small and homey.

Also, she felt it was now necessary to augment the family income in helping to plan for the children's education. However, she did not want to take a minimum salary job that did not require any skills. Therefore, she decided that college was the answer. The major concern she had dealt with her age:

Imagine. Me in a classroom at my age with recent high school graduates. I mean I have gray hairs; I've been married for more than fifteen years; I have kids. What would I have in common with them? What would the professors think?

She soon found out that there were other students her age and older in class and that the professors were oblivious to her age.

Instead, she became engrossed in her studies and the possible goal of becoming an elementary school teacher. An opportunity to test that goal presented itself when her college history instructor talked about the values of volunteer work and told the students that they could earn extra credit in the class if they did volunteer in the community and kept a journal of their activities. When she picked up her children from school that afternoon, she entered the administration office and asked to see the principal or assistant principal. She met the assistant principal and told her about what Susan's 
history instructor had said and asked if there were any possibility of volunteering at the school. The assistant principal said that they needed a volunteer in the school health clinic and to possibly help with other school activities. Susan accepted the offer and was asked to start the following day. Her history instructor approved of her volunteer activity. By the end of the semester, Susan had logged thirty-nine hours at the school.

I never expected to do more than the required twenty hours, but I guess I really enjoyed what I was doing and just lost track of time. It was really a rewarding experience. Imagine, enjoying what you're doing and getting twenty-five extra points!

\section{Personal Growth}

From Susan's perspective this was volunteer work. At the beginning of our interview sessions, she didn't understand the concept of service-learning. The fact that she didn't understand service-learning didn't seem to stand in the way of the beneficial results that service-learning professionals associate with this paradigm. It seemed to have a positive impact on her own personal growth that she had not thought about. It seems that service-learning does not have to be related to a college course to necessarily have meaning. However, it is more in-depth and reflective than volunteerism. During our interview sessions, she voiced the fact that volunteer work was supposed to help others.

I was doing this to help out at the school. I mean, if I could help and get extra credit, well, that would be great. It seems like the schools always need extra help, being shorthanded and all.

We usually think of volunteerism as a free offering of our services to help 
others without any thought of self gain. The only compensation for the volunteer is the satisfaction of doing good, and, in most cases, it is the agency and the clients of that agency or organization that are the recipients of the volunteer's efforts. This is not service-learning. Service-learning is an active pedagogy in which students provide a service to a community and become engaged in this experience to the point of gaining knowledge, skills, and perspectives that, among other expected outcomes, help them grow as individuals.

One day I was called to watch a teacher's class. It was a third grade. While the students were quietly reading, one little boy started to act up. He got up and started to knock books out of other kids' hands. I walked up to him and took him sternly by the arm and asked him to sit with me and read to me. After a few minutes, I smiled at him and told him he read well. He just kind of looked at me, and when he saw I meant it, he smiled back. Later, I told the teacher what had happened. She congratulated me and told me that I handled it well. That made me feel great. I felt like, "Hey, I can deal with these kids."

Susan had touched on an important point that service-learning advocates have written about. Service-learning can have a positive effect on self-confidence. I asked Susan to share with me how she had reflected on this in class discussion groups, in her journal writing.

I never thought about my self-confidence until you brought it up just now. We didn't have discussion groups in class. I mean our volunteer work didn't have anything to do with our class work. We did it; that's all. But that experience did make me feel good. I guess it did make me feel self-confident. It's just now that I see that. There was a connection that I didn't see. I don't know how else I would have had that experience. I wrote about it in my journal, but I never connected it to my self-confidence. I just wrote about it as something that happened. 
I asked Susan if she would share with me what she wrote. Susan's complete journal is composed of five, type-written pages. There are no dates on any of the entries.

I was asked to take Mrs. Williams class for a while today. One little kid whose name I found out is Willy acted up. I think I handled it real well, and the teacher thinks so too. I'm happy about that. ( from her written journal)

It was never explained to Susan why she was keeping a journal. The term "reflective journal" meant nothing to her. As far as she was concerned, the purpose of keeping a journal was just to make sure that she was doing her hours. The journal itself was never referred to during the semester. She handed it in to her instructor at the end of the course and never heard about it.

Though it hadn't crossed Susan's mind at the time and, obviously, had not been used as a valuable service-learning lesson by the instructor, Susan now realizes that she had a powerful learning experience that had positively affected her personal growth.

I couldn't wait to get home and share this experience with my husband. He always says that I'm too easy with kids, my own and others. He says I let them walk all over me. I showed him, and I guess I showed myself also. Wow! ( With this "Wow!" Susan turned red and her eyes watered. She seemed overwhelmed by the connections she was making.)

Susan admitted that she had never thought about this before. It had never been brought to her attention. Here was a clear example of personal growth that until now lay dormant. As we can see in her journal entry, there was no sense of reflection. When 
Susan mentioned that she thought that she "had handled it well", reflection would have

helped her see all of the elements that had gone into her action and how this episode had helped build her self-confidence to use again and again in the future instead of one isolated event.

\section{Academic Skills}

Susan kept repeating in response to questions about how her service experience impacted her course skills by saying:

This was a history class. There was no connection to my volunteer work at an elementary school. I mean, what connection could there possibly be?

Yet, Susan did share an experience she had had at the school. She talked about the assistant principal asking her if she would help out with a carnival the school was planning. The theme of the carnival had to do with learning through diversity. susan was asked to be in charge of a group of students who were to plan games for Latin America. While we were talking about her work in helping plan for the carnival, Susan said something interesting.

The students and I were looking through library books for games that kids play in that part of the world, and some of the kids had asked their parents who were from Latin America for ideas. Just then, I remembered a game I had read about in my history class when we were talking about everyday life in the Aztec culture. It was a game that the children played. I told the kids about it, and they were real excited. We started planning what we would need for the game. Afterwards, some of the students said that it was there favorite game. 
Though Susan had made a connection between her college class and her volunteer work, she had not consciously seen the connection because she had not been given the skills to reflect on her service-learning and make those valuable connections that could have made this experience both valid and timely. I decided to make Susan aware of this. As we talked about it, Susan got a slightly shocked expression on her face. I asked her what she was thinking about. She shifted in her seat and pushed her eyeglasses up with her pudgy index finger.

It's just that you're saying things that make sense to me now. I guess I did take more interest in class after I worked with the carnival. I wish I had said something to the instructor about it. There just didn't ever seem to be time. I'm just now finding out things about this service-learning that seem real interesting.

If Susan had been asked about the connections between her academic skills and her volunteer experience, she claims she would have said:

I don't see any connection here. Volunteer work is one thing and my college classes are another. I mean, if the instructor didn't bring it up all semester, I guess he didn't see any reason to.

This was no longer the case. Susan now saw that her course and her volunteer work did, in actuality, go hand-in-hand.

From our talking, I can see that my career plans are more solid because of this volunteer 
work; that I can think about it, and I'm sure about what I want to do. I guess that thinking is like the reflection you keep mentioning. Even when I teach in the future, I'll be able to use what I learned in my history class.

That this whole process was coming together for Susan even affected me. I was so happy for her. To see her finding value in this experience that she had not had the opportunity to do while she was doing service-learning was like watching a child discover a new sensory adventure, a new pleasing taste, sound, sight, or the feel of something comforting. Susan's volunteer perspective was one based on caring.

I love being with young kids. I'm concerned about them.

I want them to have a childhood. They shouldn't grow up before they've enjoyed their youth. You know what I'm saying? From what I see in my neighborhood, I wonder if parents really care about their kids. Too many parents seem so interested in themselves. They don't take time for their kids.

Susan shared that her mother would be horrified by such things.

Mama always said that once you have kids, you have a big responsibility to them, and if you don't want that responsibility, don't have kids.

Citizenship Skills

One of the most important areas to consider in service-learning is making students see the importance of being a valuable member of a community, a larger 
community than the college campus or the street that she or he lives on. It's important that students doing service-learning are aware of community needs, learning how to solve those needs through hands-on action, valuing differences among people in the community, and finding meaning in their service work. I have got to admit that I was a little (actually, more than a little) concerned about the volunteer work Susan was doing. Being at an elementary school didn't exactly seem to me to be rolling up her sleeves and getting involved with a societal issue that could possibly have better related to her college class subject matter, but, to my surprise, there were what seemed to be some valid, social issues. Susan brought these to my attention as we spoke.

Working in the health office, I saw the need to have a qualified nurse in the school. Especially in the elementary schools here in Broward. I've gotten involved with the PTA and another parents' group that are getting out petitions about it. If something bad happens to a child and there's no trained person to help, too much time may pass until help arrives. It's just not right.

The classes are just too big, too many students for one teacher. I saw that the day I was asked to help out in a classroom. I'm also getting involved with this issue. My husband says I better watch myself, or I'll end up in jail or president of the PTA and I'll make him get involved. (Sue reddens and laughs.)

Most definitely, Susan plans to get her future students involved in action learning, and she hopes that she can serve as a role model for them. In her journal, she included a poem she had written which says in part, "What better reward than someday for a child to come to you and say 'thank you for giving me of your time. You gave of yours, now I am giving of mine."” 
Susan had found issues to get involved with that are valid problems that confront our community. Susan had found meaning in her service. Discussion groups in the classroom and the keeping of a reflective journal would possibly have made Susan aware of this much sooner. Would that have made it an even more valuable experience? I'm going to ask each reader to decide that for herself or himself.

Susan has come back to visit with me two times since our interviews ended. She is very interested in knowing more about service-learning and has borrowed books from my office library on service-learning. I have also shared with her information from the Office of Volunteerism and Leadership ( The O.V.A.L. Office) at the College. She doesn't understand why she does not remember ever seeing any of this written material before. She is particularly interested in the reflection focus on affecting future change. Though she doesn't come out and say it, I have a hunch that as a result of this study she feels that there is a lot more to service-learning than she got out of her so-called "servicelearning college course." I have no doubt that I will see more of Susan in the near future. She'll timidly knock on my already open office door and shyly ask if I have any more information to share with her about service-learning. As usual, it will be my pleasure to share any information with a student who is eager enough to request it.

\section{Ellen's Perspective}

Ellen is nearing her mid-forties but she looks much younger; she is small and petite with brown hair. She dresses in traditional type clothing that might be associated with a New England college in the 1960's, penny loafers, plaid skirts, white 
blouses, and navy blue sweaters. Ellen exhibits many nervous characteristics including exaggerated gestures, fast talk, and the ability to cry easily. At first, I didn't understand why, but as we talked and got to know each other, the reasons became quite clear. As an infant, Ellen had been diagnosed with viral encephalitis which caused right side paralysis. She later displayed the signs of epilepsy and spent much of her childhood years traveling to neurological research centers. The doctors convinced her parents that Ellen was an excellent candidate for experimental brain surgery. For the past several years, Ellen has been seizure free; however, she is on a protocol of anti-convulsive medication which either tires her or, at the other exreme, gives her anxiety and nervousness. She says that she would rather deal with these side effects than seizures. Since 1981, she has been married. Her husband is a native Floridian who owns a dental lab. His work is demanding and it takes a great deal more than a typical eight hour work day. She admits that her illness has caused a great deal of hardship that has strained the marital relationship, yet she and her husband continue trying to make their marriage a success. There are no children. Medications have made it impossible for her to bear children. Instead, she readily shares photos and stories about her dogs. One of the dogs, the oldest one, was with Ellen throughout her illnesses and was a great comfort to her. Her husband has accepted the dogs in his life as surrogate children. Ellen shared that she sometimes wonders if she didn't make a mistake in not adopting a child when she and her husband were a little younger, but then adds that she feels that her illnesses might have been too much of a burden for a child. Also, she may not have had the strength to care for a child.

I just couldn't do that to a child. At times I feel cheated, and I'm concerned that my illnesses may have cheated my husband of having a child, as well. But I'm a perfectionist, and I couldn't have a child grow up in a haphazard environment. 
From the trust that grew out of the interview process, Ellen shared with me that she places a lot of pressure on herself to perform to the best of her ability.

\author{
I will not give up. Once I start something, I have \\ got to see it through right to the end. If not, I con- \\ sider myself a failure.
}

While this may seem like strong motivation for success, it may also serve as a barrier to self-acceptance. If taken to an extreme, it could lead to negative, selfdefeating thinking. My intuition told me that this could very well be part of Ellen's anxiety, in addition to the anxiety already being caused by her physical condition. When we talked about this, she admitted that the doctors have encouraged her to carefully monitor her thinking that challenges her competence and self-confidence, so that they can recommend assistance in addressing these problems when they arise.

I would never knowingly do anything dangerous to myself. If I see that I need help, I'll ask for it. I'm realistic and I enjoy life. It's my life, and I have to accept it for what it is and work with it.

Because of what she has been through, Ellen has a keen desire to help others cope with difficult situations. For this reason, she was interested in getting the college education that she had missed out on at an earlier age. She had no idea what she would do with a college degree, and she was very concerned about sitting through lectures and doing homework. The reason she had chosen Broward Community College was because it was close to home. She was not allowed to drive any great distance and, anyway, she felt that she would get more personal attention at a community college. For this reason,she was very interested in getting involved with service-learning when during her 
first semester, the instructor introduced this novel concept in the English preparatory class for students who had not passed the Freshman English Composition class entrance test.

This was something new to me. It sounded so interesting. The instructor presented this and told us that this was experiential education. We would use what we were learning in class out in the community and use what we were doing in the community for class discussion and as subject matter for our writing assignments. It was something I never heard of before.

The instructor invited the director of Community Connection (the name of The O.V.A.L. Office at that time) to give a presentation to the class.

Justine, I remember her name, was so vivacious. She handed out information and told us what was happening at other community colleges here in Florida. She talked about an organization called Campus Compact, so interesting. She asked us to read what she had given us and that she would come back to answer any questions and help us locate service sights and fill out the paper work. Then, the instructor talked to us about how learning and serving could be matched together and make the learning process more meaningful. It sounded perfect to me. Helping others means a lot to me and so does doing well in college.

After meeting with Justine, Ellen chose to work at a homeless and hunger project at a Catholic church in Hollywood. Ellen is Catholic and felt that she would be comfortable in such a setting. At first, she helped prepare and serve meals, but after a while her duties included tutoring some of the homeless children and, later on, helping 
organize the church's weekend fair to raise money for community homeless projects.

I really felt like I was doing something valuable and I was using this as subject matter for my class papers. I don't really like to write, but I enjoyed doing those papers. They were a piece of my life. When my instructor reacted to them enthusiastically, it made me feel so proud. Even if there was a problem with grammar or punctuation, I was eager to correct it. It was a whole new experience for me. The instructor was taking an interest in me. He was accepting me for who I was.

It was quite clear that Ellen felt that she fit in after so many years of feeling different. A great deal of this seemed to be due to the instructor's positive influence. The entry I made in my personal journal for that interview session included a note regarding the impact we educators can have on the lives of our students and what a responsibility this is. I wondered about how many students I have helped like this or possibly hindered. It is an issue that we as educators have to face and respond to, at least to ourselves.

\section{Personal Growth}

Ellen shared with me that while she was involved with service-learning, she felt really good about herself.

I was really relating to others. At the church, all the people were working together with one purpose in mind which was to somehow help solve this homeless problem. In class, we were sharing what we were doing. We were making a difference in our community and discussing it and writing about it. It was exciting. The reflective journal was helping me write my class papers. I remember now, we were also reading a book, Give To Live . It was written 
by a psychologist, I seem to remember. He talked about the benefits of doing good for others and for yourself, at the same time. For most of us students, especially the younger ones, this was a totally new idea. I've shared that book with so many people, including my husband and my mother. What a powerful book.

Through the interview process, Ellen was reliving the enthusiasm she had felt doing service-learning in this course. I asked Ellen if she felt empowered because of this experience.

Oh yes! That's it exactly. Friends and family members, especially my mother told me how I had changed. My mother who had seen me depressed and quiet most of the time was very happy with the change she saw in me. I couldn't wait to get to the church, and then to class to share my experience and write about it. I guess I had found my niche. This was me. I never knew that classroom work could be so vital, so pertinent to life. I have to thank my instructor for this and taking time to understand me.

I asked Ellen if this experience had helped her make any career plans.

Not at that point, no. I was enjoying the process and hadn't really given too much thought to a job or future profession. I guess I was making up for all the years I had lost being sick. I just wanted to enjoy being a college student. My husband calls me a late-bloomer. (She laughs) I tell him that in actuality we haven't been married for eighteen years. After the brain surgery, I was so out of it that I lost three or four years of my life, my married life, so career plans are on hold for the meantime. 
At our next meeting, Ellen surprised me when she said that she had thought about her career plans since we had brought it up, and now she had made a decision. She wanted to counsel disabled students at the community college level.

They need counselors who understand them, who can go to the faculty and explain their needs. The disabled also need someone who is willing to confront the administration. I mean no one seems to understand nor care about us. I'm disabled; I know what's going on. They have to accept us and provide minimal accomodations. It's the law, but they won't go one step beyond what the law requires. Don't they think we know it? We're disabled, not stupid.

This is quite powerful talk coming from a lady who only a few years before had spent most of her day sedated and resting. Not only had she found a career, she had found a cause. Ellen's perspective of service-learning was one of empathy for all disabled students. Added to this was a strong desire to do something about it. It was obvious that Ellen was awakening to the world and her place in it. Without a doubt, she now displayed self-confidence and empowerment.

My instructor recommended another book to the class. It was Og Mandino's The Greatest Miracle in the World. I never expected an English class to be such a valuable experience. I had prepared myself for boring grammar and punctuation rules that I would learn for tests and after I finished college I would gladly forget. This class was nothing like that. We were using grammar and punctuation but for interesting writing projects. 


\section{Academic Skills}

Ellen talked about never being a great student. Her life for so long had been held captive by illness that school had been a minor priority. She was a victim of medical opinion, a schedule of medicines that kept her from functioning clearly, and mandated rest periods. It was only recently that she had been put on medications that didn't tire her out. Yet, Ellen's doctors were concerned that her participation in service-learning on top of her course schedule might be too demanding, and that she might suffer academically. If so, this would defeat the whole idea of her going to school to have a life that could attempt to find some normalcy.

At first, Ellen was as concerned as her doctors; academic work was enough of a threat. Did she really need the service-learning option added to it? The thought of writing papers frightened her, but service-learning changed that. She now says that it gave her a reason to write. She was eager to share her service experience.

I couldn't believe how well I was doing in class. That's not to say that I didn't have errors in my writing, but I knew that I could correct them. This was helping me tutor some of the homeless children. I was actually helping them with school work, mainly reading and writing. I was helping them do things I was learning in my college English class.

Service-learning talks about the possible positive effects on students' academic skills including a better understanding of course material, the ability to apply course content in every day life situations, and the ability to communicate more effectively. Ellen was displaying all of these and more. She was even demonstrating leadership skills in class. 
When the instructor and the director of Community

Connection talked to the class about taking part in collecting food for the homeless for Thanksgiving, I was eager to take part. It turned out that I headed the project for the Communications Division classes. I organized the posters, the collection locations, the lists of what kinds of food would be needed and some other things. Again, my family and my doctors couldn't believe I was doing this. (A hearty laugh) I couldn't believe it either.

It didn't end there. Because of her efforts and the success of her work, Ellen was named the co-chairperson for the campus Hunger and Homeless Awareness Week. This effort and her grades earned her the George F. and Virginia Young Scholarship. She was also honored at the Community Connection Faculty Service-Learning Workshop "Your Students Will Love To Learn" which took place in February, 1995. Ellen never did service-learning again. She couldn't find another class that offered it. I asked her if this concerned her.

Concern me? I'm angry about it. To my knowledge, there never was another faculty workshop, and only a few instructors even bother using service-learning. I don't know why. A lot of students, including me, gained a lot from that experience. Not all students took part in it in my English class, but they're the losers is the way I look at it. Many of them dropped out of class during the semester anyway; others didn't pass. Maybe if we used service-learning in many more classes, more students would take an interest in education. I know what it did for me.

I asked Ellen if she felt that service-learning should be a requirement in 
certain college courses. She thought for a while and then said:

\author{
Why not? I think it would be a good idea. We're \\ so worried about students dropping out or not \\ showing any interest in classes. This might help. \\ I know what it did for me. I still visit with that \\ instructor. He gives me good advice. He was \\ interested in each one of us. He taught us more \\ than just subject matter; he taught us about life. \\ Something else. even the students who weren't \\ doing the service for the class had to read Give \\ To Live, and the instructor required them to keep \\ a reflective journal. He didn't want the class \\ broken into two camps. Some of the \\ students who didn't do service told \\ some of us students who were that \\ they were sorry that they didn't do \\ it. Maybe it was the enthusiasm we \\ were showing. Maybe.(All this said \\ with a cheshire cat grin.)
}

\title{
Citizenship Skills
}

Though Ellen had been ill for years, she seemed very aware of community needs and problems and the responsibility that members of a community should have.

I consider myself a religious person, and part of that, I think, is serving others. One of the biggest problems in our community is homelessness and hunger. If I can help another person turn their life around, that would be great. It bothers me to think that children are placed in this situation. My service-learning class gave me an outlet to do more than I would normally do. I liked doing it as part of my college education. Look, it got me the scholarship. 
Ellen and I talked for a while about the place of citizenship skills in the college curriculum. She felt that it was very important.

If the schools don't teach about being a good citizen, who should? It seems that parents aren't doing it. I see it as a part of education. Isn't our college education supposed to prepare us for life? Well, our community and what's happening in it are a part of our lives. I don't like sitting in a classroom, like history, and learning what happened a few hundred years ago unless the instructor can show me how it relates to today. Do you see what I mean?

Ellen was voicing a concern that current educators seem to feel impacts many of our students today. Namely, that they don't see the relevancy of their formal education to issues in life. If this is the case, why wouldn't more students take part in a service-learning option? Why wouldn't they demand that instructors incorporate servicelearning in their classes?

We're not really in control of our education. Do they really care what we think? Too many students don't think or don't care to think. They're mainly the younger ones. Maybe with more older, oops, I mean mature students coming to college that will change. Older students won't be hood-winked as easily, and I think we're concerned about our community and an education that has practical value. We don't have time to fool around.

Ellen admitted that working with the homeless helped her become more tolerant of others, as well. 
Being sick for so long makes you see that judging others is a waste of time. I think

I'm more tolerant of other people and their views. I think the Give To Live book had a lot to do with that. Also, many of the homeless women were no different than you and me. They didn't want to be homeless. I kept thinking, "There but for the grace of God go I." It's a sobering thought, let me tell you.

Ellen exhibited many of the positive effects of service-learning that the literature addresses. It seems that her instructor had a thorough understanding of the service-learning concept and was willing to include it in his curriculum. Additionally, it appears that the Community Connection office was active in creating a positive atmosphere for instructors to include service-learning in their classes and also had offered a good deal of support to the students who took part in the service-learning experience. Ellen was very aware of the college material about service-learning and said that her instructor had referred to it a lot during the course. She especially remembers his giving everyone in class, whether they were doing the service option or not, articles written about the value of service-learning by the Associate Vice President for Student Affairs, Judith Berson. These had been published in educational journals.

They were very positive articles with a win, win approach. It almost sounded like high school cheer leaders. Maybe that's what's needed to motivate a lot of the students. I think it worked with us.

Ellen's experience with service-learning was, obviously, a very positive one. Not only did she enjoy her class work, but she saw the relationship to a community issue, and she had done something about it. This resulted in her having more self-confidence in her abilities and being motivated to take a stand with problems in the community. 
I met Ellen on campus only last week. Quite a while after our last interview had been conducted. We both stopped; she asked if we could talk. We went to a quiet area on campus with benches and shade trees. She was visibly upset. Immediately, she blurted out that her chance of graduating was in danger; eventhough, she had a "B" average. It seems that she is taking a math course needed for graduation, but she is not doing well. She shared this with her doctors who said that they can understand why. It seems that her brain surgery has somehow affected the area of her brain that deals with mathematical type work. In addition, they gave her a story written by a woman who holds a Ph.D. in chemistry and who also had gone through the same surgical procedure. At present, the woman is very frustrated because she cannot do the math needed in her work as a chemist. Ellen's doctors have agreed to write a report to the College. The College has set up a meeting for Ellen to go before a committee to plead her case. Ellen admits to being frightened by this, but she is adamant in finding the strength to carry through with explaining her situation and asking for a waiver.

I really believe that my English class with the service-learning option and those great books we read have given me the confidence to stand up for myself and others. But, I'm nervous just the same.

Today, March 8,1999, Ellen called and asked if I would write a letter to the committee since I am so familiar with her case. I plan to do so. I've been trying to think if there is any ethical issue that should concern me here. I can't seem to think of any, but it is a concern. Even thinking about the possibility of an ethical issue at a time like this makes me cringe. What self-respecting person would retreat when action is needed? What would that say about service-learning concepts of empowerment and responsibility? Professor, practice what you preach! 


\title{
Siri's Perspective
}

I must admit that when Siri appeared and introduced himself to me, I was shocked. I didn't expect to see a six foot tall, dark blonde, green eyed young man with very pale skin. His name had led me to expect someone from India, and I told him that.

\author{
Actually, you're kind of right. My parents \\ are Americans who converted, before I \\ was born, to the Sikh religion. I guess it was \\ during their college days when the hippies \\ were drawn to everything eastern. Anyway, \\ when I was like six years old, they packed \\ me off to a boarding school in India, and I saw \\ them maybe once a year.
}

Though Siri spoke without prodding, I noticed a reserve in his demeanor. He admitted that he was learning how to act with American students. He didn't have many typically American friends because he had spent all his school years outside the U.S. Right now, while he attends Broward Community College, he is living with an aunt. He chose this specific community college because it was close to his aunt's house, and because he felt that he could re-inforce his academic skills to be able to transfer after two or so years to a four year institution. At this time, he still wasn't quite sure what he cared to major in.

After being in school in India, he chose not to move back with his parents.

I'm grown; I'm an independant person. There's no need for me to live at home. (A pause as he looks down at his hands folded in his lap) It really isn't my 
home anyway. I can't ever remember living there. It means nothing to me.

Though Siri wouldn't say it, I made an entry in my personal journal wondering if this included his parents. There seemed to be a strained relationship that he wasn't willing to talk about, and I didn't feel it was my business to delve into. Toward the end of our second interview session, he admitted, without any coaxing, that he still doesn't see his parents often. They live on the West Coast of the U.S. and pay his expenses including a new Lexus and indulge his taste for stone crabs and premium grade vegetables and fruit.

Siri was not willing to talk about his youth and growing up, either. He seemed to be one of those haunted people who might live a life based on early childhood deprivations and not successes encountered in later years. From the little he was willing to say, it seemed clear that his parents had done well economically, and Siri enjoyed material goods, as a result. He also shared with me that he baked as a hobby.

I really like making fancy desserts, especially cakes. It relaxes me. It's nothing I'd want to do as a profession,though. I mean, I don't think there's a lot of prestige connected with being a pastry chef.

Siri seemed to be very taken with impressing people. His clothes, for all of our interview sessions, had visible designer labels, and he mentioned his Lexus a few times. The first impression that he made on me and that I recorded in my personal journal was that he seemed rather snobbish. I soon learned, however, that this appearance was a result, as I have shared with you, of childhood experiences. As a result, he felt it safer to disguise his true feelings and remain somewhat aloof. He later admitted to me, "If I don't get too close to people, they can't hurt me, right?" 
When I asked Siri why he chose to take part in a service-learning option, he said, without a moments hesitation, that he wanted the extra credit that was offered.

It didn't seem like it would be difficult and I could use extra credit. When the professor spoke about his admiration for volunteering and how important it was, it seemed like a good idea and, hopefully, it would make a good impression on him.

Siri, like Susan, was not sure what service-learning was. He said the professor had made available a list with volunteer opportunities, and he chose the one that seemed convenient. Siri's choice was as a counselor with the Campus after school program for elementary school children. I asked Siri to explain to me what he did.

Well, I had fun. We played ball, ran around the field. Then, we came in for snacks; after that we helped the kids with their math and English. That was about it.

When we talked about the social value of this activity and how it made a difference in the community or furthered Siri's understanding of civic responsibility, Siri stopped me.

Wait, wait. What are you talking about?

All we were expected to do was volunteer, not change the world and our outlook.

Though Siri didn't have the faintest idea about the concept of servicelearning, he mentioned things that demonstrated to me that volunteerism does have 
connections to service-learning. He was, somehow or other, displaying signs of a service-learning experience, the outcomes that are talked about in the literature. I was puzzled. Here I was interviewing a student who, it was claimed to me, took part in a service-learning experience. A student, who by his own admission, had no idea what service-learning was. I could only think of what the sociologist, David Riesman, had said,

"Sometimes it's best to decide early on what you're not going to find out... ." That meant to me that I had better understand and respect the line between finding and reporting valid information and digging for information and becoming an irritant. I didn't want to do that. For this reason, I was surprised when Siri started to talk about valid servicelearning outcomes.

Personal Growth

Working with young children had made him realize things about himself that he had never been aware of.

I never thought that I could relate to young kids. I never had sisters or brothers. At school we were kept in age groups and separated by sex. I can't say I liked all the kids, but some of them were really cute. After the first few days, I really looked forward to being with them. They would come running up to me calling my name. I had never experienced that before. Some of them told me that both of their parents worked and didn't have a lot of time to spend with them, so this after school program was really important in a way. 
I asked Siri if he had entered what he had just shared with me in his journal and how he had reflected on it.

\begin{abstract}
Yeah. I guess it's in my journal, but reflect on it. Do you mean think about it. What it meant to me? (I told Siri that that was what I meant. He was silent for a few seconds with a serious look on his face.) I guess it meant that I could relate to these kids, some of them anyway. That made me feel good. ( Silent pause) I was helping them with their homework, and they listened to me. For a minute, I thought how great it might be to teach these eager young kids. They seemed to want attention from someone.
\end{abstract}

I asked Siri if he could think of any one occasion to share in which he had related to a specific child. He was pensive for a while and shifted uneasily in his chair. His body language seemed to tell me that he wasn't quite sure if he wanted to share such a personal event with anyone. Then he began.

Well. Geez. One day when I got to the play area, one of the kids, a boy about six or seven, came running up to me yelling my name, "Siri, Siri, I thought you weren't gonna show up today." I picked him up and twirled him around. He was laughing hysterically. When I put him down and we were both laughing, he said, "My dad travels a lot for his job. While he's away, is it okay if I think of you as my dad or older brother?" Whew! That blew me away! I mean, I was never too close to anyone in my life, and here's this kid I've known for maybe three weeks. (Siri stopped talking; his eyes were moist.)

I thanked him for sharing that very personal story with me. It was obviously difficult for him to do. Siri had come into touch with emotions that he didn't realize he 
had deep inside. If you remember, he mentioned early in our first interview about not getting too close to people so as not to get hurt. Suddenly, he continued.
When I was this kid's age, I was really hurt that my parents had sent me so far away. I decided I wouldn't beg them to come home. I would show them that they weren't all that necessary a part of my life. I don't want to talk about this anymore. Can we go on to some- thing else?

Somewhere in Anna Karenina it says that all happy families are alike in their happiness, but that unhappy families are unhappy in their own very personal way. This had been a very emotional moment for me as well as for Siri. I was moved by what had been said, and more by the feelings these words were expressing. Siri and this child had shared a very special moment. Later, I looked through Siri's journal ( all of the participants in the study had given me the right to copy and use their journals); Nowhere was this written. Had it been so personal to him that he hadn't even wanted to have a written record of it? Was he blocking it out? At this time, I felt like I might be intruding. I proceeded cautiously, not wanting to disrupt our dialogue. For a few minutes, I felt it necessary to stop and reflect on what had taken place. I offered Siri a cold drink and we just talked about inconsequential matters for a few minutes. Siri had talked about his new-found self-confidence in working with children and also how he related to these children. These are important signs of personal growth. But, of what good are they to society or the individual student, in this case, if they are not reflected upon, shared in dialogue, nor related to the course curriculum? A vital opportunity to make this a powerful learning experience had been wasted. Service-learning professionals might not see this particular student's volunteer work as a valid service-learning experience, I'm not sure that I did when he first told me what he had done as service-learning, but 
surprisingly the outcomes point to the fact that there was personal growth in this situation. He even mentioned thinking about a career in teaching youngsters. I asked him to expand a little on what he had said.

\begin{abstract}
(A blush preceded the spoken word)
No. It was just a thought. I want to live the good life. I could never live on a teacher's salary. Besides, my family would be furious with me. I mean everyone they know has jobs that are prestigious.
\end{abstract}

What do I make of this statement? Do I let it speak for itself? Realistically, it seems that personal growth is an ongoing process. As long as we are alive, so is the possibility of personal growth. At this point, Siri is still concerned about his parents' opinions and beliefs. Though it seems that he has more self confidence in dealing with others from this experience, he still does not have that self confidence in relating to his parents. Clearly, building self confidence, relationships to others, and empowerment in one area of our lives does not automatically translate to all other areas. It is a one step at a time process. I could, at this point, speculate on the psychological ramifications of what Siri is saying, but that would be unfair to him and really not a part of this study. Will Siri ever become an elementary school teacher? Anything is possible in life.

\title{
Academic Skills
}

John Dewey (1938) said that while " all genuine education comes about through experience (this) does not mean that all experiences are genuinely or equally educative." In this he included the relationship between the student and the curriculum 
which could further be applied to the service-learning transactions that take place as part of learning, both formal and informal. I bring this up here because of what transpired when Siri and I talked about the relationship between his service experience and its connection to the academic work going on in the classroom. Siri quite emphatically told me that he felt that this particular instructor was one of the best he had had here at the College, yet he could see absolutely no connection between his volunteer work and the course material.

Why should there be any connection? We were doing volunteer work for extra credit.

At this time, I would like to share with the reader the dialogue of what was said verbatim.

Interviewer: Siri, can we talk about how your service work was used by your instructor to apply to your class work.

Siri: My particular volunteer work? (Siri consistently used the word "volunteer" and not "service-learning" since this is what had been used by the instructor.)

Interviewer: Well, the students who had chosen to do service-learning.

Siri: $\quad$ (Pause) Our class had nothing to do with what we were doing for extra credit. How could one relate to the other? I don't see what you're driving at.

Interviewer: Well, did you ever discuss your journals in class? Did you relate your service experience through writings for the instructor?

Siri: $\quad$ Our volunteer work was never brought up once we started it. It was totally separate from what we were studying in class.

Interviewer: What finally became of the journal you were keeping?

Siri: We handed it in on the last day of class. What became of it after that, I 
don't know. Now you tell me you know where it is, so you know more than me. All I know is that I got my extra credit and that gave me a really good grade in class. It was 25 points.

Dear reader, are you as flabbergasted as I? Service-learning emphasizes the point that the academic class informs the service, and the service, in return, informs the class work to make this a vital experiential adventure. I am saddened to think that this was a wasted opportunity. In this case, it was not so much the experience that was miseducative, but the manner in which it was handled. How could the office that oversees service-learning not have been aware of this situation? It seems that once the instructor adopts a service-learning option, the office bows out and does not involve itself. Academic freedom may be involved here. It could be a very political issue which calls for a great deal of diplomacy. Whatever the issue, students like Siri are missing out on a very valuable learning experience that could have been used to clearly show them how their formal class work relates to life in general. No use was made of reflection, nor application of course content, nor communication skills, nor critical thinking skills.

When we talked about any possible motivation that Siri had had to do better in class as a result of his volunteer experience, he didn't seem to see the connection.

I don't think I was motivated to do any better because I worked with these kids. I mean, I think I would've gotten the same grade whether I did this or not. (pause) Well, I got the extra credit if that matters.

Siri couldn't understand how his so-called "service-learning" could have motivated him to do better in class, and he was right. How could he have seen this possible benefit of service-learning if it had never been explained to him. I was, however, 
hoping that he could see the relationship of service in the community to his academic studies.

I mentioned to Siri that in tantric texts from India, there is a strong streak of contempt or, at least, condescension for those people who limit themselves to intellectual knowing and do not take part in experiential replication. Siri said that even though he was not familiar with these texts, while in school in India, the students had been expected to do chores around the school so that the school would be an example to the community.

\section{Citizenship Skills}

The chores that the students were expected to do at the school in India neatly led into the area of citizenship skills as they related to Siri's service-learning. We talked for a while about this.

I think what I was doing was filling a community or social need. Here we had young kids who, if not for this program, would have nowhere to go after school. Who knows what mischief they would get into if they were home alone or with an older brother or sister. At least, we had physical activity, snacks, and study time where they could get help. Tutoring. Yeah. I think I had social responsibility.

I never thought I would be sorry when it ended, but I was. I would do it again. I think I really see the need for people to volunteer now. You know, the instructor told us how involved he was in the community, so I did this for the extra credit, but now I guess I would do it even if extra credit wasn't offered. As long as I had time to do it. 
As I said before, I didn't, at first, see the social value in what Siri was doing, but I guess that there was some social value in it. Siri saw this as meeting a community need. Would it have been of any more social value if it had taken place at a poverty project or a community center with children of the economically disadvantaged or minorities? This is a question that those of us who support service-learning will have to answer. But let us heed the warning that we may be making a value judgement here. What is clear about Siri is that by the end of the interview sessions there was a selfunderstanding that didn't seem to exist before or was well hidden. If his instructor had been trained in the concepts of service-learning, he may have been able to help Siri see how his volunteer experience was somehow transforming his values and attitudes. Siri's perspective was one of attachment and the fear of attachment. My intuition tells me that he purposely chose to deal with children because they didn't pose as great a threat as adults. In the final analysis, this positive experience with the children may help him deal better with the demons in his life. The demons that we, as humans, are all too aware of at one time or another, aren't we?

\section{Nestor's Perspective}

Nestor is a twenty-two year old hispanic student who is originally from New York City. To be more specific, his father's family is hispanic, from Puerto Rico. His mother is North American whose family is a mix of English, Irish, and German. He said that he understands a little Spanish but cannot speak nor write the language. This has served as a barrier to developing a close relationship with his father's family. In no way 
does this mean that Nestor doesn't wish to communicate better with his father's family. As a matter of fact, at the time of our interviews, he was planning to take part in a study abroad semester program in Spain which would give him the chance to learn and practice the language in a native setting.

Nestor was cooperative during our interview sessions but not especially expansive in conversation. During our first interview session he said that before he took part in the volunteer experience, he had already decided that he wanted a career in the law enforcement field. When he started college, he decided to remove a gold earring and give up the "rap" attire he had previously worn. He was concerned about the image he portrayed; even though, he admitted to not being part of "the system." He chose Broward Community College because it was conveniently located and cheap. "Well, not cheap, but cheaper than those bigger colleges, and money doesn't come easy." He shared this information with me in a rather bland manner, no facial expression, no more words than needed to convey his meaning. He was not familiar with the term "service-learning" nor what it meant though he had done volunteer work, as he called it, for two consecutive semesters. Any student who chose this option was asked to do at least twenty hours of a volunteer activity by the instructor.

We were told to do at least twenty hours, and that's what I did, no more, no less. I did it to get extra-credit. If there were no extra-credit, I wouldn't have done it.

What he did was to volunteer at the Broward County Sheriff's Office. After a two hour training class on volunteer rules and regulations in the sheriff's office, he was asked to work at the inmate leisure library checking all books for contraband or 
pornographic material that inmates might have been passing to each other. During the second semester, he was assigned to the information desk at the main jail, downtown, Ft. Lauderdale. He found both positions to be rather boring. When I asked him if he had asked about other volunteer opportunities, he said he had, but that the Volunteer Services Coordinator at the sheriff's office had told him that nothing else was available. He had hoped to work more directly with inmates. In a letter to the O.V.A.L. Office at the end of the second semester, the Volunteer Services Coordinator at the sheriff's office stated that she had moved Nestor through several departments so that " he can perceive earnest service-learning in a criminal justice administration environment." Nestor did not feel that this statement was particularly valid. Though he had filled out a form for his instructors to volunteer at the sheriff's office, he did not remember seeing any other written information explaining about the O.V.A.L. Office nor the idea behind servicelearning. As a matter of fact, he didn't remember ever having heard about the O.V.A.L. Office and was not aware of its existence.

\section{Personal Growth}

Nestor could not find any value in his service experience outside of earning himself extra credit in two classes he had taken that offered this option. Yet, he told me that it was during this time that he had decided that he wanted to study criminal law and not criminal justice.

I saw all these police officers and the jobs they were doing and the money they were making, and I decided that it wasn't for me. I want a better life. I want the good things in life, fancy home, cars, maybe even a boat, and I don't mean a rowboat. 
I heard the way these guys talk about the inmates. I don't like it. Many of these inmates haven't even been found guilty yet, but they're treated like subhumans. I saw this happen before here. I saw it in New York with friends and a couple of family members. Somebody's gotta look out for these guys. It might as well be me. I'll make a bundle off the system. Why not?

This made me think about comments I had heard Mathilde Krim, a leading scientist in AIDS research make. During a T.V. interview she talked about her lack of tolerance for institutional restraints and about how institutions should serve people. How people become prisoners of the system that ultimately make them ineffectual. I entered this in my personal journal because Nestor seemed to me to be sure of himself, like the kind of person who realistically understands what raw material he has to work with and goes about inventing himself. He displayed ambition, but I fear this raw ambition.

Wittgenstein talked about ambition being the death of thought. Without a mentor, a professor, to help guide this ambition, Nestor's ambition could end up frustrated; this could be disastrous. This is where a mentor in the service-learning process could help direct this potential.

I shared with Nestor that Margaret Mead, a famous anthropologist, had said that she measured success in terms of the contributions an individual makes to her or his fellow human beings. He said:

I guess it's true. But, I also measure success by money and material goods. It's natural. Everyone I know does. Try living without it and see how you get treated. I mean, this is reality. 
Later on in our second interview, Nestor said that maybe the comments he had made a while ago about the police were a little too harsh, too quick to judge.

These guys don't have it easy all the time. The streets are rough. I just feel that the criminals have to get a fair shake. You know what I mean? The way it is, there's nothing fair about it.

Nestor did not realize that his statements were clearly indicating personal growth. This service experience, whether he had yet realized it or not, had helped him make a more definite career choice; even though, we, professionals in higher education, might not agree with his motives. At the same time, he was modifying his perception of workers in the criminal justice system based on what he had seen and heard at the sheriff's office during his volunteer experience. When I repeated what he had said to make sure that I had understood it and to make sure he realized what he had said, with a very straight face he said, "I guess what you say is true." I responded, "No, Nestor, I didn't say it. You did." He responded, "Maybe I did." For the first time, he displayed a faint smile and shook his head slowly, up and down. Nestor seemed to realize that his ideas were changing. This indicated personal growth. If he had not volunteered at the sheriff's office, would this change have taken place? Did this opportunity serve as a catalyst? Could this be considered a fragment of a service-learning experience?

At this point, Nestor advised me that he had just made up his mind to continue with the interview process. I couldn't help feeling that he was just as eager to learn more about the value of his service as I was. From this point on, he was more relaxed, though still not expansive in his responses. This, I decided, was his personality. 
It didn't diminish the value of his remarks.

\section{Academic Skills}

All through the interview process, Nestor insisted that there had been no connection between his service and his class work. After he had informed the instructor that he was working at the sheriff's office, the instructor asked him to keep a journal. Nothing more was said during the course about the service work that Nestor was doing. Nestor, himself, wondered how his class in American History could possibly relate to his work at the sheriff's office. I asked him if he had written papers during the course. He responded that he had. Then, I inquired whether his instructor (I encouraged the participants not to mention their instructors' names, if at all possible, since I did not wish to personalize any comments about the instructors or instruction) had included in his syllabus any information about criminals in American society or incidence of crime, any information about the penal system or the development of the legal system.
Yeah. He did talk about how the British treated some guys like criminals and what they did to them. He mentioned about a guy who said 'Give me liberty or death'; I remember that. He thought that guy was real cool cause we had to read about him too. He also told us about real criminals like the guy who shot Lincoln and also about desperados out West. He related this to the gun issue today. It was interesting.

Topics had been discussed in class that could have related to Nestor's volunteer work, so that it could have been valid service-learning, but the opportunity had 
been allowed to slip by without notice. This could have been sound service-learning. Nestor could have compared a jail today to what it was back in American History. He could have been asked to write about the amenities in jails today in the United States such as the leisure library with which he was directly familiar. This did not happen. His journal which is one page long and was accepted for extra credit includes no reflection on his volunteer work nor any of the course content related to criminal justice or the lack of justice. After we had talked about this, he still insisted that he saw no relevant connection.

This class was American History before 1900. What could that possibly have to do with my volunteer work in a jail library in 1998 ?

I reminded Nestor that he had just told me that the instructor had made a valid connection between gun-toting desperados in the wild West and the gun issue today. Could he now see the connection between law enforcement in those days and nowadays?

Maybe so, but my instructor was teaching his class which had nothing to do with my volunteer work for extra credit. He was a good instructor. He made class interesting.

I felt it necessary to assure Nestor that in no way did I mean to say or insinuate anything negative about his instructor's abilities as a college instructor ( I repeat, we did not mention the instructor's name). I was merely trying to get Nestor's own reflections on his service-learning experience. In this particular instance, I wanted to 
gain insight into how it had related to his academic work, if he thought he had done better in the class as a result of his experience in the community. I also wanted to hear from him whether he had learned anything in class that he could, in return, use or share out in the community.

(Pensive pause) No. I really didn't work with anyone, just books. I would've liked to talk to inmates, but it never happened.

We have to ask ourselves if students should be allowed to volunteer in positions that are not beneficial to their learning, or should I say positions in which students are not made aware of the service-learning benefits. Where was the servicelearning experience in Nestor's case that could positively impact his academic performance and have him help others in the community, so that he could make the connection between his formal learning and its application?

\section{Citizenship Skills}

Though Nestor kept insisting throughout our interview sessions that he saw little to no connection between his service experience and his class, he shared with me that he was now, more than ever, aware of problems that existed in our community in relation to the criminal justice system. He was concerned about talk he had heard and reports he had seen relating to overcrowded conditions in the main jail. Over time, he became aware of what, he considered to be, unneccessarily long prison sentences for nonviolent inmates. 
They were there for something as stupid as, for example, stealing food to feed their kids. If they were rich and had connections, they would've been out in less than an hour. It's ridiculous that these people should be taking up valuable cell space.

Nestor rarely smiled during our interview sessions. Somehow he felt that doing so was a sign of weakness. I couldn't help but feel that he was taking life too seriously. He was intent on focusing on the lack of social justice in this society of "haves" and "have nots." I asked Nestor what he thought he could do about it. Kurt Lewin had said that "If you want to truly understand a problem in society, try to change it." An opportunity like this could lead to his own sense of empowerment and self-worth if handled correctly.

Well that's why I've decided to go into criminal law. I can make changes from a position that has power. Down the road that's what I want to do.

But, I asked Nestor, what can you do now? You've seen this situation with your own eyes. You have the opportunity now. It's the learners and doers who inherit the future. There was a few minute period of silence. I wanted Nestor to take time to reflect on what we had just talked about.

Yeah, there are too many people spending far too much time in prison. I'm concerned about it. I don't want you to think I'm not, but I have 
school and a thirty-hour a week part-time job.

Let people who have the time get involved. You

know, it was hard finding the time to volunteer.

This is a very personal decision that a person has

to make, to do volunteer work. If it was required

instead of an option, I would probably switch

to another college. (Pause) It's not that I don't

want to get involved. I know that there are problems

in the community, but I don't have the time to deal

with them. I guess that being at the BSO (Broward

Sheriff's Office) really made me see that this is a

rich man's system. It needs to be changed. It's

not a fair system. There is no fair system in this

world. I bet that in the future I will make a difference.

This was a service-learning experience on the verge of happening. It could have been made an integral part of the curriculum of the course to demonstrate to Nestor the inter-relatedness of his class to life in the community. The last thing that Nestor said during our last interview is worth repeating, "I bet that in the future I will make a difference." My question is, why should this have to wait for the future? This would have been the right time to have had him reflect on the importance of citizenship skills to his studies and his life in the community. As I said before, Nestor displayed a great amount of ambition, but, I fear, unsophisticated ambition. In his comments, he touched on the relevant issue of citizenship skills many times, in both positive and negative ways. This was the perfect opportunity to have culled his interest in people he thought of as abused by the system and to have helped him find his voice in order to make a difference now, as well as in the future. His voice could have helped make a difference before the present passes out of existence.

During our last interview session, Nestor mentioned to me something that I wish to share with you (and this he said with a half smile). 
I liked talking to you. After the first session, I really felt comfortable. I want you to know that everything I said is how I really feel. If I was asked to write about my work at the BSO or to have answered questions in writing like on a questionnaire, like choose "A", "B", "C", I would have said everything was great. Most of us students do that. We don't want to make the instructor look bad. We don't want it to look like we didn't get a lot out of what we did. We know what you want to hear. Talking to you was different.

Nestor's perspective of a volunteer experience was one of social justice. He was going to try to outwit the system to help the under-dog. From this volunteer experience he hadn't expected any personal gain, material nor nonmaterial, but there had been personal gain all the same. Personal gain that was now clear to him as a result of our interviews.

\section{Glenda's Perspective}

Glenda is a housewife, mother of two teenagers, and full-time student who is in her late thirties. She is vivacious and speaks in an animated, breathless fashion, green eyes flashing, arms flying in the air and descending to comb through her short yet abundant reddish-brown hair. She is the product of show business parents. Her early years were spent on the road and watching her parents rehearse song and dance routines. By her own admission, she tired of it. She lost interest in her dance and voice classes and 
longed to have a permanent home and friends. Eventually, she married early and had a child within the first year. Glenda was eager to establish roots and a stable family that lived in a house in a community with neighbors.

It was what I wanted, but I couldn't get performing out of my system. It's like it was part of me. I tried to block it out (she said with a theatrical toss of her arms and an exasperated laugh), I couldn't. I was born to it. Geez!

Glenda was in college because as her children got older, she was concerned about what she would do when they left to go to college. She didn't want to sit home. She would be too old to perform professionally, but she could teach drama, dance, voice, and direct shows. That was it; she would become a certified teacher. Broward Community College, Central Campus, was her only chance to attain this goal.

I've got a family. How else could I do this? I say thank God for the community college. It sure has simplified making decisions about my future.

When her instructor mentioned the option of doing volunteer work in the community, Glenda immediately thought about the Western High School production of Li'l Abner that she had been asked to help out with. She approached her instructor and asked if he would approve of this as volunteer work for extra credit. He did.

Glenda used the term "service-learning", but she didn't understand what it meant. She claimed that it was never explained. The instructor handed out the forms to fill out. She never met anyone from the O.V.A.L. Office but thought that her 
professor was somehow connected with it. All she remembered was that she was told to keep a journal to be handed in at the end of the semester. Nothing else was ever mentioned again during the course in relation to service-learning.

\section{Personal Growth}

Considering what Glenda had shared with me, I couldn't see how this could, in any way, be a valid service-learning experience, but again I was in for a surprise. Glenda, who was a great communicator, told me that she had been asked to help with a production of a Broadway show at the high school and would have done it whether her instructor at B.C.C. had approved of it or not. The fact that he did made it that much more worthwhile.

Glenda looked forward to this opportunity not only because it involved show business, but also because her daughter was a student at Western High School and was going to be a cast member. As is typical of mother and teenage daughter, there had been a little tension in their relationship lately.

She would say "yes", and I would say "no." She would say "red", and I would say "blue." You know what I mean? It wasn't anything serious; it was just little annoyances. My husband said that he may have to referee. So, this chance to work together was a challenge. I really didn't know if it would be good or not. I was a little tense about it.

Glenda choreographed and coached the students on how to use their voices for projection in relation to lines and songs. She worked hard at it and spent a lot of time 
with the students. She got to know her daughter's friends better. They openly talked about school and their personal relationships in front of her.

It was almost as though they wanted me to hear. Like they wanted some adult advice. At first, I just listened and made believe I didn't hear. I held myself back from getting involved. One day, one of the girls was off key. She asked me if she could rest for a few minutes; she had had a rough day, but she didn't move. She stood right there. I took that as a sign that she,maybe, wanted some help. I asked her if everything was okay. She told me that her boyfriend had told her that if she didn't get intimate with him, he didn't want to see her anymore. I asked her what she felt. She was obviously confused and didn't know what to do. I asked her if she would consider discussing this with her mother. She didn't want to because her mother had a very conservative moral code and would point blank tell her what to do without listening to her. I asked her to think seriously about it and not do anything until she had made a decision she could be comfortable with. I mean this is a heavy load for a sixteen-year-old. She came to me the next day and told me that she had decided that she didn't want to be intimate with someone who was a casual boyfriend and was going to tell him to accept that or get out of her life. I hugged her and she hugged me. We cried and laughed. That night my daughter told me on the way home that Bev had told her what we had talked about. She told me that all the girls thought I was "neat." Then she said that she did too. I got a lump in my throat. I pulled the car to the side of the road and gave her a big hug. I cried. She told me that I was so emotional, but her eyes were wet too.(pause) I can't believe that I'm sharing this with you. My daughter would be so upset with me. 
I asked Glenda what this had meant to her personally. I asked if she saw this as an opportunity for growth.

Well of course. There was my daughter complementing me. I felt like a fairy god-mother. I was walking on air for days afterwards. I could relate to these teenagers. They were now willing to come to me for advice. I could understand the problems they face. Boy, did that build my self-confidence. I was flying, but I also realized what a responsibility it was. My son joked, and my husband also, about my being the high school's Dear Abby.

I also learned that I have a lot of patience. I never realized this before. It takes a lot to work with a large group of people, especially teens.

As you can see, Glenda had no trouble when it came to conversing with me. She was very open and honest in what she said. If she had not been so open in her remarks, I might not have seen the personal growth that had occured. Yet, at the same time, I am very aware that most everything we humans believe and report is based on our prejudices. Very little in life is objective. Jurgen Habermas (1970) argued that none of us could avoid being prejudiced, but hopefully through reflection and the researcher's insightful questions and remarks that we can somewhat overcome biases. I also feel that the researcher must make use of her/his intuitive abilities here. In talking about her seemingly honest comments, my mind-set was geared to service-learning being based on working with a social problem in the community. Working on a school play did not seem to fit neatly in with that idea. It was something that might be ridiculed in the literature. Yet, here was a woman who saw this as an opportunity that had led to her personal growth. She, herself, admitted to increased self-confidence. Would it have been clever of me or professional to have told her that this service-learning experience was not of value 
because the problems of teenage girls in a middle-class setting are not social problems with which the community is concerned? If this girl who had confided in Glenda, or the other girls like her, become pregnant, would it then become a social problem for the community to deal with?

\section{Academic Skills}

Glenda, like all but one of the others I had interviewed saw no relevant relationship between her class and her volunteer work.

The class was history. It had nothing to do with my volunteer work. Once we started our volunteer work, nothing more was said about it. We just handed in our journals at the end. What became of my journal? I don't know. (A shrug)

I asked Glenda if her volunteer work had helped her make a career decision. She had mentioned teaching voice or dance but hadn't mentioned anything about career goals.

At my age career goals? Well actually, this service-learning got me interested in teaching. The show went over really well. I got a lot of great feedback. The drama teacher may be moving away in two years, and the principal told me that they would use me on a part-time basis with an associates degree. Doesn't that sound like a great incentive to get my degree and go on for a four-year degree? I think it's exciting. 
We talked a little about how she was doing in her college classes. She said that she had never really planned on getting involved in a degree program, but that as things were progressing, it looked very probable.

This is really snowballing isn't it?

I'm determined to do well in my classes now. It's a little frightening when I think of all the requirements, but I feel that I can do it. I've got a possible job waiting for me. I'm spending more time studying now. I want to do well.

While Glenda was talking, I couldn't help but wonder, as I had with three of the other respondents, if this would have been a more valuable experience for them if they had had the opportunity to better relate their volunteer experience to their class work. I too have to call it "volunteer" because so much seemed to be lacking for me to call it a "service-learning" experience. How much more valuable it would have been if Glenda had kept a reflective journal. Her journal reminds me more of diary entries with matter-of-fact information of her day-to-day choreography work. Nothing in it is reflective, nor does it relate to her academic work. It would have been more meaningful to her if she had been able to share with her instructor and classmates, had been able to relate, in writing, her community work to the history of musical theatre in America, for example. After all, musical theatre is very much a part of American History as are the simple, farm type people and scheming politicians and businessmen that make up the cast of characters in Li'l Abner . 


\section{Citizenship Skills}

We talked for a while about a service-learning experience in enhancing awareness of community concerns, involvement, and helping empower a person or group of people in the community to become problem solvers. Glenda immediately saw a connection.

\begin{abstract}
My working with these kids helped them become much more out-going and I saw their self-confidence grow. I was empowering them. Through acting, through drama, I believe, people learn to deal with life's problems. Don't we have enough teens in trouble? Isn't this a community concern? I saw it first hand. I got involved with it. Teens are easily intimidated. I saw them grow through this production. Maybe we need more drama classes or workshops in our community to help people work out problems in their lives. Take on a different persona.
\end{abstract}

It got me involved in the community. I've been asked to come back and work on the school's next production, Bye.Bye.Birdie. I was also approached by a couple who asked me if I would be interested in doing some community children's theatre work for kids with mental disorders and learning disorders. That should be a great learning experience for me, as well.

Glenda was not sitting home anymore. She thought that when she started college that she would go to class, be lectured to, and have lots of homework to occupy 
her time. She never thought that agreeing to work on a school production would lead to such a keen desire to teach theatre arts. She never expected to get so closely involved with the students who were participating in the show; additionally, she was now getting involved with children's theatre. She called me at the end of November to share with me that she was working on a holiday production with children from five to twelve years of age. Glenda said it wasn't easy since the children all had some disability, but they were trying so hard to do well that it was becoming a labor of love. She was even asked to get involved with a community grant to supplement the funding for the children's theatre. Glenda was thrilled to be involved with this community effort.

Glenda's perspective of her volunteer experience was one of involvement. She longed to create the neighborhood, the community, that she lacked as a young person. She was finally fulfilling a need that had been neglected and she saw as desirable and necessary. 
Name

Susan

Ellen

Siri

Nestor

Glenda thirty-something

elementary education

mid-forties

twenty-four

twenty-two

criminal law

secondary

education

theatre arts
Reason for

Volunteering

class option for extra credit

interest in a valid

service-learning

experience

class option for extra credit

class option for extra credit

class option for extra credit

Figure 4.2 


\section{Summary}

Just as trial lawyers sum up their cases before the jury, I feel it fitting that we do likewise in order to review the main points that we have just covered in presenting the data. The data in this chapter was presented in categories that were organized from the themes and linkages that became evident in the data as a result of our interview sessions and subsequent meetings to discuss the data after it was transcribed.

As Figure 4.1 (p.67) informs us, these five participants' perspectives on service in the community all to a greater or lesser degree did involve personal growth, was related to academic skills, and did embrace citizenship skills, as well. In addition, Figure 5.1 (p.115) shows us that Susan's perspective in working with elementary school students was based on a sense of caring. She came to love these children not only in a professional manner, but as a mother image. Since her work was volunteer, she didn't, at first, see any personal gain in it, nor did she see any relationship between her volunteer activity and her academic studies. Siri's perspective dealt with attachment and, more specifically, the fear of attachment. Though he didn't realize it at the time of his involvement with these youngsters, he had formed attachments that had made him come into contact with his emotions. His experience might have been more potent if it had been treated more as a service-learning experience and less of one based in volunteerism that ignored the potential benefits of a service-learning encounter with its reflection and concern for active learning. Nestor's perspective was based on a sense of social justice. He had hoped to get more involved with inmates instead of doing clerical chores associated with a volunteer, but, he felt, there was no one to help him in this matter. He had grown, however. For example, he now saw the frustrations that police had to face as part of their jobs. At the same time, he became more convinced that petty criminals lacked social justice. If this had been handled as a service-learning experience, Nestor 
would have had a greater opportunity to reflect on his service work, discuss it in class with other students who may have opened this experience to other points of view, and Nestor may have more clearly seen a connection to his academic studies. The same might have been true for Glenda. Her perspective was one of involvement. By getting involved with a school, musical production she was establishing stronger roots in her community. This too could have been a valuable service-learning experience. Instead, it ended up being volunteer work which lacked the dimensions of a service experience. It wasn't until our interviews that Glenda saw what a valuable encounter this could have been for her. Of all the five participants, only Ellen was aware at the time of her service that she was taking part in a valid service-learning experience. She was supported in seeing the positive connections of her academic studies to her community service work and even came away from this experience with firmer career plans and self-empowerment. Her physical rehabilitation and acceptance of herself, led her to live an examined life that helped her relate to the homeless population she dealt with in the community. Her service aided her in seeing the meaningfulness of her experience. This new found power is now helping her confront a problem associated with a college requirement that she wants the B.C.C. administration to substitute with other classes that better fit her mode of learning since her brain surgery. She admitted that she would never have been able to face a situation like this before her experience with service-learning.

\section{The Role of the Researcher Revisited}

In Chapter Three, I talked about the role of the researcher, but this was more in theoretical and abstract ways. Now, that I have actually completed Chapter Four, I find 
that I must expand upon what I had previously said. I have found that the analysis comes, in part, from playing fantasy games with myself. As I analyze a problem or bit of information if I am stuck for an answer, I imagine being asked questions that I have to respond to in writing. The author Faulkner said that he didn't know what he thought until he read what he had said. This is as good as any argument I have ever heard for keeping a personal journal during the research process. It seems that we learn what we think by codifying our thoughts in some way. From the interviews, I also learned that to be a researcher, one must be willing to explore and listen carefully; it's necessary to take in as much as possible but not accept anything uncritically. In the end, one must learn to respect intuitive thoughts and hunches after scrutinizing them with sound logic and discipline. I have also learned the value of ethics and acting ethically. This, I believe, is what builds a feeling of trust with participants in a study. You cannot know this until you have actually taken part in a valid qualitative study. The poet and philosopher Emerson alluded to this when he said that what you are speaks so loudly, that he could not hear what you say.It also seems much clearer to me now that a good researcher must make every attempt to know herself/himself. William James (1878) said:

I have often thought that the best way to define a man's character would be to seek out the particular mental or moral attitude in which, when it came upon him, he felt himself most deeply and intensively active and alive. At such moments, there is a voice inside which speaks and says, "This is the real me."

When we are in the role of the researcher, this is the way we must feel. If this passion does not exist, it will be evident in the reported research. The action of 
research calls for a continual reflection; it seems to become a lifetime process. During, and even after the study has been concluded, there is a hunger to delve deeper, to know more, and I have found that it dominates the researcher's attention until it is satiated. One keeps hammering away or, to be more exact, becomes the hammer instead of the anvil, as Goethe said.

I now know that as a researcher in helping participants in a study to find their truths that the uncovered truth is useless until the respondents understand what is their experience. They will not know this until the researcher helps them find it through reflection. This is a big responsibility that can frighten a novice researcher, and so it should. It is the constant act of reflecting that leads us to understanding, and it is also in our relationships with others that we come to see our truisms, so it is for the participant in a study, as well as the researcher. Too many people in the world today exist with a group mentality. Boris Pasternak (1958) wrote:

Well, what are you? What is it about you that you have always known as yourself? What are you conscious of in yourself: your kidneys, your liver, your blood vessels? No. However far back you go in your memory it is always some external manifestation of yourself where you come across your identity: in the work of your hands, in your family, in other people. And now, listen carefully. You in others- this is what you are, this is what your consciousness has breathed, and lived on, and enjoyed throughout your life, your soul, your immortality - your life in others.

What a paradox! It is up to the researcher to assist the participant in finding her/his unique voice and her/his reality. In the role of the researcher, I must help the respondent find her/his individuality through voice and action. To somehow wade through the currents of conformity to find her/his truth. We are asking the participant to 
examine her/his experience and find meaning in it. As Socrates said, "The unexamined life is not worth living." It is the researcher who has the responsibility of helping those people who participate in a study to learn. Too many college instructors are still caught up in the traditional mode of teaching their students instead of having them learn through an experiential mode based upon the philosophy of Jean Piaget and John Dewey, among others. If I remember correctly, Albert Einstein talked about it being a miracle that traditional methods of instruction have not strangled the curiosity of inquiry.

Doing a study has taught me a lot about the reality of the role of the researcher, and what I find so challenging is the vast amount of knowledge that I must still acquire to continue as a researcher if I am to become a good researcher in helping people find their "selves" and allowing them to emerge.

Chapter Five presents the conclusions of the study. The implications of the conclusions, as well as the recommendations for additional research. 


\section{Chapter V}

Conclusions, Implications, and Recommendations

\section{Introduction}

The purpose of this study was to describe and explain the perspectives on a service-learning experience of five students at Broward Community College, Central Campus. Describing and explaining refer to the process of analytical description that represents the perspectives of the respondents accurately, vividly, and convincingly. In using the participants' exact words, I hoped to provide detail and realism. It is hoped that this will help the reader to better understand what the interviewees said in these living conversations and why I have come to my conclusions.

Steinar Kvale (1996) shares with the reader the purpose of the qualitative research interview being "the description and interpretation of themes in the [subjects'] lived world"(p.187). Therefore, the researcher has a perspective on what has been investigated or studied and interprets the interviews from this perspective. This is a going beyond what has been directly said to working out relationships of meaning. That is, meaning to the people involved in the study and their specific situation.

The organization of the categories and the presentation of the data was determined by the data collected. As such, the explanation of the perspectives of the participants is part of an entire process that includes the mode of presentation. The description of the perspectives is determined by the data as interpreted by the interviewer. As a result, this study is limited by the data collected. The goal being to understand the perspectives of these students as they relate to a specific experience.

A prime focus of this study was to ascertain if a service-learning experience 
had a beneficial effect on any or all of these five students who had taken part in a class that offered a service-learning option from the students' perspectives.

The exploratory questions of this study provided a foundation for the interview process. It is through the process of describing and explaining these perspectives that meaning was found. The exploratory questions that guided this study were:

1. What elements constitute these students' perspectives?

2. What variables influence their perspectives?

3. What beliefs do these students hold about their servicelearning experience which support or are contrary to their perspectives?

The formation of analytical categories described in Chapter Three provided the basis for the description and explanation of the students' perspectives. The analysis of the data provided insight into the perspectives experienced by each interviewee (Figure $5.1)$. 
The Model For The Study

\section{AN INTERVIEW STUDY OF COMMUNITY COLLEGE STUDENT PERSPECTIVES ON SERVICE-LEARNING}

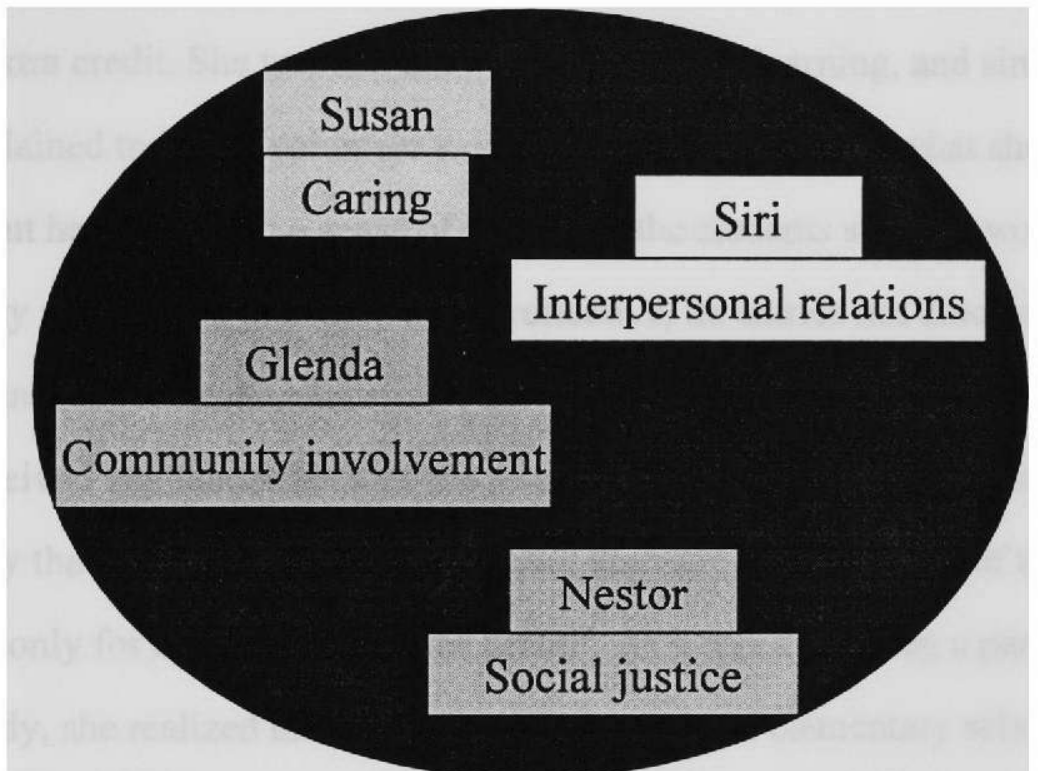

No visible connection between classroom and community

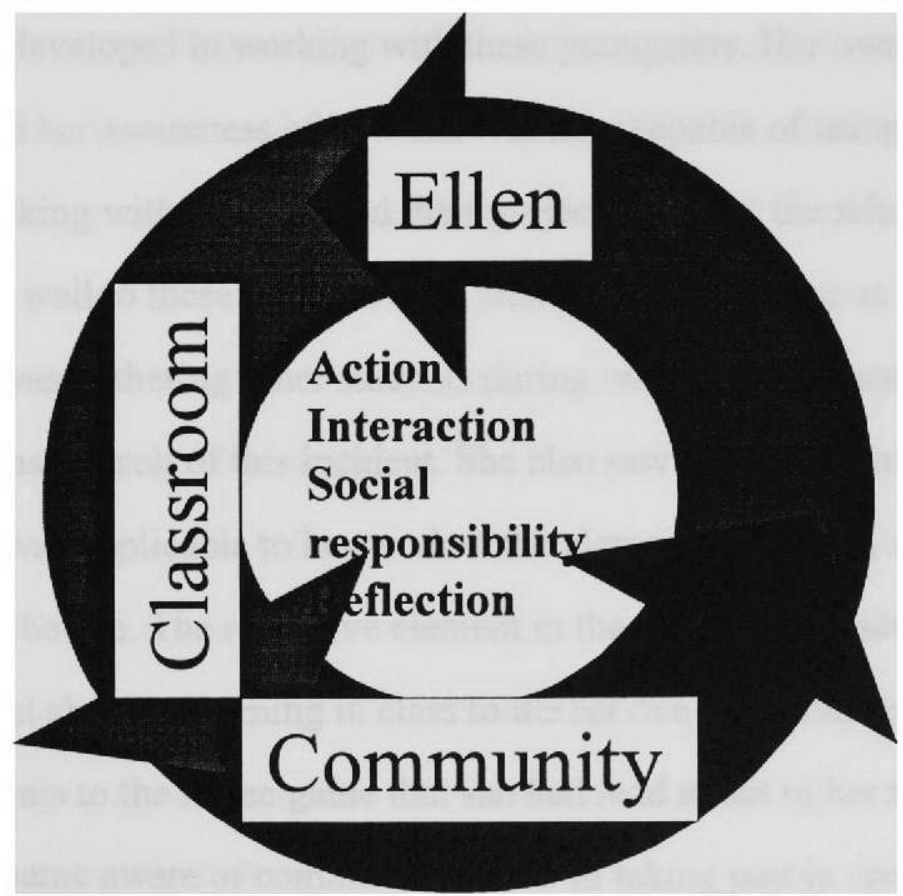

Classroom work informs community action and vice-versa Figure 5.1 


\section{Susan's Perspective on Exploratory Questions}

Susan's perspective on the work she did was one of doing a volunteer type activity for extra credit. She was not familiar with service-learning, and since this project had been explained to her as volunteer work for extra credit that is what she saw it as. She carried out her work with a sense of caring for the students she was working with at the elementary school. Her journal was not reflective, its entries not discussed with others in her class, and, as far as she was aware, her instructor had possibly never read it since she never received any feedback from the instructor. It was when she participated in this research study that she became aware of service-learning and the value of the work she had done not only for the students but for herself. As a result of being a participant in the interview study, she realized that she wanted to become an elementary school teacher because of the valuable experiences she had shared with the students and the selfconfidence she had developed in working with these youngsters. Her own personal growth also included her awareness of how she was now capable of using problem solving skills in working with students and their projects, such as the school fair. She saw that she could relate well to these students even when a problem arose as in the case of the youngster who was bothering other students during reading time. Susan admitted to feeling empowered as a result of this incident. She also saw during the interview process that course content was applicable to her work at the elementary school; something that she had not realized before. The reflective element in the interviews made her see this. She had applied what she was learning in class to the service situation, such as when she introduced the students to the Aztec game that she had read about in her text. During her service, she also became aware of community needs. In taking part in community efforts regarding the need for licensed nurses in the schools and limiting class size in elementary 
schools, Susan was getting involved in helping to solve social problems. Many elements existed in Susan's experience to make it a valid service-learning one.

\section{Ellen's Perspective on Exploratory Questions}

Ellen had been introduced to service-learning through her course. The concepts of a valid service-learning experience had been explained fully to her and other students in her class who had chosen the option of taking part in a service-learning experience by the instructor and the service-learning coordinator. Her experience in working with the homeless was based on empathy for other people that stemmed from her years of illness and lack of self-control. Through her service-learning experience, she talked about achieving a great deal of personal growth which is reflected in her reflective journal which she shared with others in class and which the instructor had used entries from to create writing projects for Ellen. She feels that this process helped her gain empowerment which, in turn, bolstered her self-confidence. This increase in selfconfidence led her to make career plans. She had decided to become a counselor to work with disabled students, possibly at the community college level. In relation to academic skills, Ellen, who had been leery of the writing process, was now looking forward to writing papers related to her service-learning experience. These papers gave her time to reflect on what she was doing in the community, to communicate her service with others, and to apply all of the rules of English grammar that she had once dreaded. At the same time, Ellen, whose life had been isolated from others because of sickness, was now taking part in her community and becoming aware of that community's problems. She was developing a sense of social responsibility and finding meaning in her service. She was taking action to help others and, at the same time, was benefiting through more confidence and motivation which, in turn, increased her academic skills. She not only 
successfully finished her course, but, as a result, was awarded a scholarship. In her interview participation, she credited service-learning for her new-found personal and academic success.

\section{Siri's Perspective on Exploratory Questions}

Siri was willing to do the service option for the extra-credit. He thought it might also make a good impression on the instructor who had talked to the class at length about his own volunteerism in the community. But, Siri was totally unaware of what constituted a valid service-learning experience. He saw no connection between working at the college's after school program for youngsters and the history course he had taken. His journal amounted to seven handscribbled pages which did not make use of reflection. During the interviews, he talked about a growing fondness for several of the children and a growing attachment. This had not been revealed in his journal. From the interviews, he saw that there had been personal growth in his ability to relate to a few of these children. This reflection was hard for Siri to accept since he didn't seem to be comfortable with relating to other people. It later came out that this had been the result of childhood experiences. As he talked, he mentioned that he had thought for a short while about being an elementary school teacher. He was beginning to feel comfortable with relating to these youngsters and how happy he was when he was with them, but no connection was made between this experience and his course. He saw absolutely no connection to academic skills, and nothing was ever done in class to attempt to make a valid connection. It was only during the interviews that Siri began to reflect on his experience and could only relate it to citizenship skills. He saw the need for after school programs as filling a need for the community. Also, he felt that he was being socially responsible in helping to provide that service; though, he had never mentioned any of this in his personal journal. 
He did not feel that he had done any better or worse in his class as a result of this experience, except for the fact that twenty-five points had been added to his final grade. The fact that Siri had learned something about himself, his concern with attachment, and had found meaning in his volunteer activity had lain dormant until he participated in the interviews, and he was still somewhat uncomfortable with his new-found knowledge.

Nestor's Perspective on Exploratory Questions

Like Siri, Nestor's perspective of his service experience was one of volunteerism for extra-credit with an emphasis on the extra-credit. During the course of his community work, he saw absolutely no connection between it and the course subject matter. Furthermore, he saw no value in it to his personal growth, his academic success, nor his civic involvement. His personal journal was not reflective and amounted to three entries that reflect nothing more than boredom. It wasn't until he participated in the interview process that he began to see that now more than wanting to work in corrections that he wanted to become a criminal law attorney. He had, at the same time, come to see the difficulty in police work and wasn't as fast to condemn the police and their actions; however, he was beginning to see inequities in the justice system that concerned him. From his experience in the sheriff's office, he now felt that he was becoming empowered and could possibly do something about it. This was personal growth. Though he still saw no relationship between his community work and his academic course work, he expressed a respect for academic education to help him achieve his goal of becoming an attorney. The biggest growth, however, for Nestor was in the area of citizenship skills. He had now identified his concern as one of social justice for criminals serving time for petty 
crimes and for a community dealing with major crime that was going unsolved because of bureaucratic entanglements. He felt that he could possibly help change the system in the future if he were to become an attorney. This is powerful information that Nestor had never reflected on until the interviews. His perspective, and the value of it to him and possibly the community, would have been lost.

\section{Glenda's Perspective on Exploratory Questions}

Glenda, as well as Susan, Siri, and Nestor, had decided to do the volunteer option for her class for extra-credit. She admitted that she had already been involved with the school production, so she was happy when the instructor approved it for her volunteerism for extra-credit. She had been involved with the production because she was interested in seeing if she really wanted to teach theatre and drama on the high school level to see if she could successfully relate to high school students. In addition to that, she was eager to be involved because of her sense of community that came from a childhood of moving around and never being able to identify with a home base. Her journal does not demonstrate any use of reflective elements, and it wasn't until she took part in this study's interview sessions that she began to reflect on her experience orally. It became obvious that her community work had made her decide that she did want to teach theatre and drama on the high school level. She felt that this was a wonderful way for students to act out problematic situations in their lives. They could act out a part and then stand back and reflect on it. She felt a growing empowerment in reaching her goal of helping students do this. This resolve had also boosted her self-confidence. She saw from this community activity that she was capable of doing a good job as a theatre arts teacher. Though Glenda did not see any connection between this work and her course, she became 
aware through the interview process that there was a connection that she had never been guided to see. More than the others, who thought of their experience as volunteerism and were unaware of the concept of service-learning, Glenda was visibly upset that she had been cheated of a valid service-learning experience and the skills that it could have helped her develop that she could, in turn, use when she became a teacher. She now saw how this experience had helped her make a career decision, boost her self-confidence, set goals to become a teacher, listen more closely to student needs, and to help students solve their problems. But, until the interview sessions, she had not been aware of these benefits on a conscious level and, therefore, didn't feel that she would have ever made use of them in a practical way.

This study attempted to add to the relatively sparse literature on students' perspectives of a service-learning experience. Moreover, a majority of the studies that do exist were conducted at selective four-year colleges where a majority of the students interviewed were recent high school graduates, attending full time, and residing on campus. Thus, there is limited research reported in the literature dealing with the perspectives of students on a service-learning experience who are non-traditional and enrolled at the community college level.

\section{Conclusions}

The major conclusions of this study are:

1. The concepts of service-learning as described in the literature are not being adequately implemented in the classes of four of the five student who took part in this study at Broward Community College, Central Campus, Ft. Lauderdale, Florida. 
2. Four of five of the participants who elected a service-learning option were not, in actuality, experiencing valid service-learning concepts.

3. Though volunteerism is being confused with service-learning, all five students who participated in the option have displayed beneficial results from the community involvement experience nevertheless. Therefore it is assumed that a real servicelearning experience would have been more beneficial.

4. As evidenced from Article 7 in the College's Mission Statement, the college is dedicated "To provide the opportunity for students to contribute to the well-being of others through student service-learning programs that are part of their higher education experience." However, commitment needs to be implemented at all levels within the College.

5. There is a need for faculty training and support in carrying out this commitment. Possible incentives might include release time, supplemental pay, and recognition at college events since re-designing courses to include a service-learning component, rewriting course syllabi, and working with the O.V.A.L. Office in planning valid service-learning experiences can be a burdensome assignment.

6. The O.V.A.L. Office personnel must support the students and the faculty members through class visitations, workshops, reflection sessions, and direct contact with community agencies where students are placed. In too many instances, students are involved in a service that is not beneficial to the community nor to the student and there is no one to intervene and rectify the situation.

These conclusions evolve from the responses of the participants in their interviews. It is their comments on their perspectives that provided the necessary data for the conclusions enumerated above.

On the whole, it can be observed that these students valued their experiences when they were asked to talk about them and reflect on them. This would confirm the findings of Conrad \& Hedin,1992; Markus, Howard, \& King, 1993; and McClusky, Fawcett \& Green, 1992. It is also evident, from what the students said, that servicelearning enhanced their self-esteem (Hedin,1989) and social attitudes (Markus et al). 
However, since four of five of these participants did not have a valid service-learning experience, we don't know from the students' comments if there was an improvement of the integration of theory and practice as observed by Markus et al and McClusky, Fawcett, and Green. It is clear from what four of the respondents said that they did not take part in regular discussion groups oriented to helping them reflect on and analyze their experiences (Conrad \& Hedin). Therefore, we will never know whether these students made gains in academic growth that are directly related to their service-learning experience. What we do know is that four of the five respondents received twenty-five points of extra-credit for choosing the option. We also know that since the students' community work was not taken into account in their classes, we must assume that their graded assignments and tests did not tap into what successful community service-learning experiences seem to most positively affect; that is, first-hand knowledge of the real world outside of the classroom, abilities in areas directly related to their service experience, and their capacity to apply concepts to the world outside of the classroom. Four of the five students didn't appreciate what they had done in the community until they took part in this study. Unfortunately, they didn't see the benefit in what they were doing, aside from the extra-credit, because they had not received enough of a basis in the service-learning paradigm to know what they should have been looking for. Therefore, they failed to take full advantage of the experience. This was definitely an opportunity lost.

Another key component of service-learning is reflection which enables the student to connect the service project with academic learning. Only one student of the five had used reflection. Obviously, there is a great deal of inconsistency as to the application of service-learning. This can affect student outcomes. In view of the importance of reflection, there is a dire need to better coordinate service projects at the College. Time devoted to reflective practices both in the classroom and during group sessions that should be provided for by the O.V.A.L. Office, but are not currently, need to 
be structured and uniform so that all students who choose the service option have the same opportunity to integrate their out-of-class experiences with their academic course material. Such recommendations are consistent with the conclusions of other servicelearning professionals (Barber,1992; Hedin, 1989 cited in Markus et al., 1993, p. 417).

\section{Implications and Recommendations}

A 1995 national survey conducted by the AACC (American Association of Community Colleges reported that " four out of five community colleges are interested in service-learning, either by actively using the methodology or wanting to do so." Also, " seventy percent of the community college respondents consider community service as part of their institutional mission." As we have seen, Broward Community College has included a statement to this effect in its Mission Statement. The question is, who's in charge of the program? Who's seeing to it that valid service-learning concepts are in use? From the students' remarks it would seem like there is a need for more organization, administrative support in the form of budget, personnel, and direction, and faculty involvement. Without faculty support, a service-learning program will not succeed. With such impediments, it is the students who could benefit from this alternative to traditional forms of education who will suffer. Two years ago, more than eight instructors on Central Campus were using service-learning as an option in one or more of their classes. In this current 1998-99 school year, an O.V.A.L. Office staff member told me that either one or two faculty members were using service-learning.

Service-learning has been called part of a revolution that is influencing American higher education (Rifkin,1996) and a focal point for rethinking the mission of 
higher education in the United States. In fact, Rifkin quotes a leading economist who considers service-learning to be " the antidote to simulation and cyberspace." If this is the case, shouldn't a community college concerned about the student attrition rate and its connection to using traditional methods of instruction for non-traditional students be more concerned about implementing alternative programs such as service-learning? Is it possible that acting as a synergist, service-learning can create relationships and transform the thinking and realities of all those who participate?

The Myers-Lipton study (1994) relates that schools can be agents of social change if they adopt curriculum and pedagogy that allows students to integrate theory and action so that the students, as change agents, can actively create new interpretations of social reality. Results, such as these, can be effective in supporting educational reformers who wish to make the educational experience all-inclusive and meaningful, as well as reflective. Despite studies, such as this one, community colleges, like Broward Community College, still find it a challenge to successfully incorporate service-learning into the institutional culture. It seems that barriers still exist, but the pinpointing of these barriers is a very arduous task. The administration, from the literature available, claims to be in support of the concept; the O.V.A.L. Office that is supposed to support implementation of the program on campus claims to be supportive of any faculty member who wishes to incorporate the service paradigm in her or his classes, yet, for the most part, the faculty seem unaware of the program's existence or have little understanding of the concept. A recent national study reported on by Astin (1995) found that eighty percent of college faculty believe that colleges should encourage their students to take part in a community service experience, yet only two percent of faculty include a service component in their courses. The challenge here is for college administrators who claim to support community service experiences to find more effective ways to influence faculty to be involved. In this study, the students' remarks led me to believe that faculty are not 
buying into the service model because of the fear of relinquishing control of their classrooms to representatives from Student Affairs and community agencies. If this is a logical inference from comments made, it is something that will have to be taken into account by the College administration. One of the greatest needs at Broward Community College, as evidenced from the students' statements, is for a more centralized organization. The participants in this study were, for the most part, unaware of servicelearning being a college-wide effort. They thought that it was merely an extra-credit exercise that their specific instructor used. There is a need for the College to explain to the students the integrative function of a college education. Students must come away from a college experience with more than a transfer degree or technical knowledge that leads to a job. They must have a sense of the social and environmental trends that will, most definitely, affect their futures. The College now educates a great diversity of students, but the community from which they come must be more beneficially affected by this better educated citizenry. It seems clear that experiential education based in reflection is called for.

\section{The Importance of Reflection}

At this point in this study, I feel that it is necessary to take time to talk in more depth about reflection and its benefits since it seems important to include more reflection in our educational process. Education should not only prepare people for a profession or trade, but support the maturation process of the human as a social being and in letting the self emerge. The student, at every level of education, must be prepared to take part in community problems and help find solutions. On the job, one of the basic skills will be how to resolve situations, be more efficient, and plan for future growth. This can only come about through the arduous task of reflection. What we are talking about 
here is the expression of self in relation to others. In too many instances, students are so busy listening to (or blocking out) parents' voices, instructors' voices, and all voices of authority figures that they never learn how to develop their own emerging voices. This frustration, eventually, leads to voices of anger and doubt. It is through guided reflection that our voices emerge. This is how we come to hear our "impulse voices" as it was called by Abraham Maslow in his research on human nature. These impulse voices help us know ourselves and help us relate to the world around us. They are grounded in instinct and impulse together with an overlay of logic and discipline and result in a true valid reflective experience. We, as instructors, have to help our students process their learning experience through reflection and activity. Service-learning can afford students multiple frames of reference and aid them in making use of analytical skills. One such skill may be through perspective and the other could be learning how to get to the core of an issue. But this reflective learning must not be abstract. Abstract thinking does not change a situation or a human being's behavior. Change only comes about through action, and action comes about through reflection. Just for a minute, let's talk about the many ways to reflect. We can reflect by looking back, thinking back, journaling, talking with others, taking part in retreats, watching movies or shows, dreaming, asking for critiques, or even just plain joking around. At this period in time and in trying to make use of reflection, we are putting too much emphasis on journaling at the expense of all of the other ways to reflect. Freud wrote about the conscious and the unconscious. From his work we learned how much information humans keep trapped in the unconscious that could be useful. But, if it is never reflected on and brought to consciousness, of what value is it? Reflection is a way of making learning conscious, and this leads to action. Yet, how many of us, even those of us involved with service-learning, take time to explain to our students the values of reflection? How many of us really understand the concept of reflection ourselves? In our teaching, it is reflection that can help us get to the 
heart of the matter; the truths emerge. Meaning becomes clearer and even the course of action becomes clear to us. Once a course of action is decided upon, we have resolution, an explanation, a solution, and isn't this what we need to face life's problems at home, in the community, and on the job?

Too often, we only take time to reflect when we have been faced with failure. Really, think about it. When do we usually stop our frenetic pace to pause and assess a situation? Isn't it when something has gone wrong? When everything is going well, we don't usually take time to reflect. Therefore, we begin to be shaped more by our negative experiences than our positive experiences because we dwell on the negatives. So, we end up reacting instead of reflecting and acting, and much of the time this is what we are teaching our students to do. Hopefully, our lives are made up of more successes than failures, but, as humans, we tend to make many mistakes. If we look at mistakes as negatives, we're lost. We have to help our students see that mistakes contain powerful lessons, but only if we reflect on them and logically see what is wrong, make revisions, and then act on those revisions. When we watch an iceskater going through a routine and suddenly fall, she/ he doesn't just sit there on the ice defeated. She/ he immediately continues on with the routine. Later, she/he will reflect on the incident to process her/his feelings, understand what went wrong, look for resolutions, and get on with the work at hand. Without reflection, we and our students can too easily become the victims of our feelings and become a useless pile of unresolved emotions. Through reflection, servicelearning can help students accumulate experiences, both negative and positive, that can serve them well for the rest of their lives. True reflection not only informs us but inspires us to act, and it is from action that our lives become meaningful. This is how we successfully develop. Erik Erikson saw our development as a series of successful resolutions of life's problems. If we don't successfully resolve these conflicts, we become immobile; our growth as humans does not advance. We all face doubts, confusion, 
delusion, isolation, inferiority and so many other conflicts, but through reflection we can learn to resolve these as we learn to make use of competence, purpose, hope, empathy, integrity, and the wisdom that comes from all kinds of experiences, and this is why the education we give our students should be experiential and reflective. This is what gives life meaning. When we teach our students to reflect on their life experiences and resolve conflicts, they can begin to develop their own unique perspectives and voices to express these perspectives. In the final analysis, these perspectives are based on particular frames of reference. All through this study, I have sought the perspectives of these five participants and their frames of reference. Since each individual is unique, it's obvious that each one's perspective is authentic and original. In the final result, we're looking at these five students as they express themselves. I was not interested in having these particular students prove themselves but express themselves. Too much time is spent in our classrooms having students prove themselves through testing and being put on the spot with oral questions that they are forced to answer in front of classmates rather than through reflection and self-expression. In proving ourselves subject to peer, family, and social pressures, we lose ourselves along the way as individuals and soon function with crowd mentality in a defensive manner.

\section{The Issue of Ethics Re-visited}

Ethical questions abound in a qualitative research study as I mentioned in Chapter Three under the Role of the Researcher. However, I feel that the reader and I should talk more about this. It is understood that the researcher has ethical responsibilities to the participants in a study including, but not limited to, confidentiality, informed 
consent, consequences of the study to the participant, analysis of the data, but it doesn't end there. In many studies, such as this one, an institution is involved. What obligations does the researcher have in this case? And what about ethical responsibilities to the field of qualitative research and other researchers in the field? Though some of these ethical issues are commonly known ahead of time, while planning the research study, other issues have a habit of popping up during the study causing the need to take time to reflect on these issues. I would advise any prospective researcher to read as many sources of information as possible to become familiarized with ethical issues. I highly recommend Eisner (1991), Janesick (1998), and Kvale (1996). There are obviously no uniform, universal codes of ethics, and that is why it becomes imperative to seek knowledge and support from those experts in the field who have written about ethics. I would even recommend dialogue with professors and classmates.

Two of my participants in this study were very concerned about who at the college was going to have access to their interviews as reported in this study. Therefore, I clearly stated in the letter of informed consent that they would remain anonymous, pseudonyms would be used to identify them, and that all tapes, transcripts, and notes would be locked in a file cabinet under code.

Aside from these concerns, the researcher also has to consider the ethical issues she or he has to herself or himself. These may include protection of the independence of the research, counteracting hierarchical issues, becoming too closely involved with the participants in a study, and maintaining critical perspective. Many times during this study, I had to stand back, look at my work, and reflect on the possible moral and ethical issues involved and the people affected including myself as researcher. For example, it became clear to me during the interviews with four of five of the participants that the people in charge of service-learning at the College and on the Campus were not implementing service-learning, and that instructors who claimed to be 
using valid service-learning concepts were not. I considered this information important to my study; I felt it my duty to report this information. What would be the human consequences? I pondered this for a few days until I decided that this was not a vendetta; I was not going to get personal, and I would report the data in as factual and non-biased a way as I considered ethically possible that would reflect well on the field of qualitative research. As the study proceeded, I came to trust my intuition and the knowledge that I had acquired from months of reading about ethical considerations. In the final analysis, the purpose of this study was to add to the existing body of knowledge concerning service-learning at the community college level and, hopefully, encourage further dialogue and written research in this area. This framed all of my ethical considerations. Yet, I wouldn't be quite honest with you if I didn't say that as this study comes to a conclusion, I'm still concerned about ethical issues.

\section{Implications for Administration. Staff, Faculty, and Students}

The implications of this study for administration and student-service staff, faculty, and students are complex. As four of the five the students' remarks, in this study, demonstrated, there is a total lack of understanding of the concept of service-learning on their parts and, it seems, on the parts of the faculty members who claimed to use it in class with these four students, aside from Ellen. In addition, the administration has to take more of a leadership role in the implementation of such a non-traditional paradigm as service-learning. Therefore, the following implications for administration need to be addressed.

There is an urgent need for the administration, which has claimed to support 
the integration of a service-learning component into the curriculum, to structure a well organized plan to implement it and to adequately support the O.V.A.L. Office, which is supposed to oversee the program on Central Campus, with funding, staff, space, and support material. The O.V.A.L. Office staff must be prepared to use any professional means necessary to train faculty, support faculty, make classroom visitations, explain the concept of service-learning to the students, supply them with literature, help them locate valid service-learning opportunities at community agencies, maintain a liaison role with these agencies, be aware of student performance and agency expectations, maintain a written record of each student's service-learning from entrance to exit, and supervise student group meetings to discuss the students' experiences and to determine the value of these experiences to see if changes are needed. This is the way we learn from past experience and plan for the future. Without a doubt, this is a great deal of work, but it must be done if we wish to offer a valid service-learning program.

It is the administration and student services staff that must offer faculty and students workshops and literature in becoming familiar with alternative programs such as service-learning. They have got to support faculty with release time and/or other incentives such as stipends to re-write course curriculums, choose texts that better serve experiential courses, collaborate with the person or people from the O.V.A.L. office who organize the service-learning experience for the student and the community agency, keep records for each of their students doing service, and working with involved students on the importance of reflection, group reflection, and reflective journal keeping.

Also, the administration must serve as a role model for students by emphasizing its commitment to a service-learning paradigm. The administration, as well, has to offer students a co-curricular transcript that lists the service work students have done as part of their college education. Many colleges, universities, and present and future employers are interested in this information about a future student or prospective 
employee. There is also a need for students to be afforded an open forum on campus through student services to meet and discuss their service-learning experiences both negative and positive and get support from each other and the input from a trained staff member who can help the students put their experiences into perspective.

People trust people who speak honestly with them, who put everything on the table and don't play games. This is the kind of leadership corporations are seeking to establish, and this is the type of administrations college constituencies should establish and expect. In addition to administration and student services staff, there are important implications for the faculty.

The implications for faculty are vital since these are the people who work most closely with the students and should be more familiar with the students in their classes than any other constituency on campus. It is the faculty who have to be committed to helping students use their voices for change. From the past until the present, in too many cases, the faculty culture has stood as an obstacle to change, not only at universities with long histories, but at community colleges, as well. For too long, faculty, of which I am one, has been more devoted to preserving these staid cultures than meeting new challenges in the field of education. We are too hierarchical when we need to be more global and collaborative. How can we claim to lead students into the future when we ourselves operate on old paradigms?

In Experience and Education (1984), John Dewey wrote:

The principle of continuity of experience means that every experience both takes up something from those which have gone before and modifies in some ways the quality of those which come after.... As an individual passes from one situation to another, his world, his environment, expands or contracts. He does not find himself living in another world but in a different part or aspect of one and the same world. What he has learned in the way of knowledge and skill in one situation becomes an instrument of understanding and dealing effectively 
with the situations that follow. The process goes on as long as life and education continue.

Change is inevitable, and it is the faculty who has to be willing and prepared to change. If a traditional mode is not working, look for or create a new one. The faculty must exhibit traits of being positive change agents, take a leadership role in experimenting with alternative modes of education, and demand administrative support in this endeavor. In helping our students, we have to work collaboratively with student services in helping our students build from their strengths, instead of focusing on their weaknesses. This does not mean, however, that we should ignore students' weaknesses. A service-learning curriculum, which makes use of many skills, can help us better see a student's strengths and weaknesses so that we can help students advance. We have to constantly focus on the fact that we are not only imparting knowledge to students for them to absorb, but we are helping to prepare a future citizen of a society with all of its ramifications.

If we don't actively help our students, could it be that we are hindering their development? Alexis de Tocqueville (1830) wrote:

I am tempted to believe that what we call necessary institutions are no more than institutions to which we have become accustomed. The field of possibilities is much more extensive than men living in their various societies are ready to imagine.

Are we faculty members capable of imagining the possibilities that exist for us to make use of in educating our students to become valuable members of our society? We must be if we are not to become prehistoric dinosaurs. In our interaction with our students, we have a great responsibility to them, as much if not more than we have to our 
disciplines. If we agree that traditional modes of education are not functioning as beneficially as we would like, there are alternatives available. As we have seen, servicelearning is one possibility. Students, as well, have an important role to play in the successful implementation of a service-learning program.

Students have a large stake in their educational process. They are spending not only money but valuable time. Since a majority of students can no longer function in traditional modes, it is important that they learn to take charge of their educational lives and learn to know themselves. This is not a novel idea; it has been around for hundreds of years, but it has never fully taken root. To know oneself comes through reflection, the examined life. Students must take time to reflect on their lives in order to assess their strengths and weaknesses. This can come through directed writing, discussion, presentations in class, and service work in the community. It is important for the student to concentrate on what she/he does well. Students are asking for a more realistic education; one that is more relevant to life. What could be more relevant than an experiential type education? Students must know how they best learn. What is evident today about many of these non-traditional students, or many undergraduates in general, is that they are active learners, concrete operational learners, who do not do well with higher-level abstract reasoning. This typifies experiential learning; therefore, service-learning is a possible solution to the many problems facing the student today as she/he attempts higher-education. Astin (1993) has also shown that students learn best and personally develop best when they engage in both academic and non-academic activities that interrelate both inside and outside the classroom. But, students, on the whole, don't yet seem to be willing to take control of their educational experience. They must take part in developing a service-learning program and not sit passively waiting for administration and faculty to create a viable program in which they are a vital part but have not taken the opportunity to have input. Students must also be aware of their value system. They must 
be taught to make short-term and long-term goals. Students must learn to express themselves rather than to deny themselves. A valid service-learning program involves itself with these issues.

To establish a valid service-learning program at a community college takes a great deal of change, and change is never easy. As a matter of fact, it tends to irritate since it usually comes when there is a problem, whether we wish to face it or not, in the form of a challenge. But, education is a challenging field, and we, the administration, the faculty, and the students, must be willing to face these challenges and do something about them. The field of higher education isn't what it was ten years ago, and, like a car, we need our oil changes and tune-ups. We need our reality checks. Change is not an enemy; it is an opportunity to grow through action and empowerment. It is this that inspires a can-do spirit. Therefore, educators in the community colleges and the students need to be responsive, innovative, and flexible. Eric Hoffer, the labor leader, once said that in times of change it is the people who are willing to learn who lead into the future. Those who are not willing to learn any more are equipped to live only in the past.

\section{Implications for Future Research}

The implications of this study lead to interesting and meaningful research questions for the future. A first major research area is suggested by the issue of empowering community college students to see the need for skills and concepts that link their formal education to community issues in a complex world. Students must learn to see themselves as more than potential employees to join the American workforce. They must see themselves as agents of change who are well equipped by their community 
college experience to affect change in the community and in themselves as valuable human beings who understand their self-worth, the value of civic responsibility, and respect for intellectual development. It might be beneficial for this research to learn from the field of feminist and post-structural perspectives which focus on the research process as a change-enhancing, reciprocally educative encounter as discussed by Lather (1988).

A second interesting research agenda is suggested by the question of community college faculty involvement in the service-learning experience. The role of the faculty member is crucial to the success of a service-learning program. She/he is the person who is in direct contact with the student and is teaching a discipline to the student. To make this discipline fit the service-learning model will have to incorporate methods from experiential education. This, by necessity, has to demonstrate the community connection of her/his discipline that the student has to relate to and reflect on. Without faculty involvement, there is no chance for service-learning to be successful. The administration must have a complete understanding of the barriers and incentives in seeking faculty participation, and also entice faculty support and expertise in designing a valid, meaningful program that will benefit our current student body. It must also be made to show the faculty what they have to gain from this experience: relating the academic world to the community and life experiences, more personal contact with the students and a chance to influence each student's growth, helping students increase civic awareness, and having the opportunity to support the students' search for career opportunities.

Related to this is the need for research in areas where faculty have concerns including academic control and quality, lack of knowledge in experiential education, lack of knowledge in classroom assessment of experiential learning, lack of community contacts and opening up the classroom to community agencies, the limitations of time to 
combine academics and service-learning, and compensation for an increased workload. There is a need for faculty to clearly see that such programs are being successfully instituted at other community colleges. They must have the time and opportunity to see these programs first-hand and be able to ask questions. H.C. Eric Midelfort, Associate Dean at the College of Arts and Sciences at the University of Virginia said that it was very important that the faculty see examples from other institutions and that the examples needed to be from other comparable institutions.

A third vital area for research is the evaluation and assessment of servicelearning programs at community colleges. The history of service-learning as part of community college programs is rather recent, as is the case at Broward Community College. You might say that we are still in the experimental stage. The program is still quite fluid with a great degree of faculty and student turnover. Many agencies in the community don't yet understand the concept of service-learning. They, like many administrators and faculty, think of it as volunteerism; therefore, the students also equate it with volunteerism. The program has not gotten a great degree of exposure nor have there been any earth shattering success stories, at least, not published. Therefore, there is little support for the program. For these reasons, there is a need to evaluate. Community colleges need to know exactly what to evaluate, what resources to use, and to consider who will be using the findings and for what purposes. There is a need for information on when to evaluate and how to evaluate. We need to discuss contexts and data collection methods. I have found face-to-face contact, piles of notes, and perceptions of people involved in the program (and even outside the program looking in) to be most valuable. If you wish to label this a qualitative method, that's fine with me. It works! We do need more information on who should evaluate and assess and how much evaluation is enough. Also, we need to see research on possible bias, values, and expectations and how to deal with this. There is a need for research related to what to do with the results of an 
evaluation, so that there is continuous improvement of practice. So called "tools" have been produced at universities for university use, but they do not serve the purpose of the community college and its unique student population.

This study suggests that there is a great need for a serious attempt to implement service-learning at Broward Community College, Central Campus, in order to put the Mission Statement into practice, and that the perspectives of students taking part in a service-learning program are vital to the success of that program in order to understand the reality of a service-learning experience.

This study has focused on the perspectives of five Central Campus students who chose a service-learning option in one or more of their classes at Broward Community College, Central Campus, Ft. Lauderdale, Florida. There is a greater need to hear the students' voices in order for us, educators, to plan programs and curriculum that are valid and meaningful. Finally, this study calls for a critical examination by administration, faculty, and students regarding the value of a service-learning program at Broward Community College and the means to implement it effectively. 


\section{References}

Archambault, R.D. (Ed.). (1964). Dewey on education. New York: Random House.

Astin, A.W. (1993). What matters in college : Four critical years revisited. San Francisco: Jossey-Bass.

Astin, A.W. (1995, October 6). What higher education can do in the cause of citizenship. The Chronicle of Higher Education, A-9.

Attinasi, L.C., Jr. (1992). Rethinking the study of college outcomes. Journal of College Student Development,33, 61-70.

Batchelder, T.H., \& Root, S. (1994). Effects of an undergraduate program to integrate academic learning and service: Cognitive, prosocial cognitive, and identity outcomes. Journal of Adolescence, 17, 341-355.

Battistoni, R. (1995, Winter). Service-learning, diversity, and the liberal arts curriculum. Liberal Education, 30-35.

Bellah, R. N., Madsden, R., Sullivan, W.M., Swidler, A., \& Tipton, S.M. (1986). Habits of the heart: Individualism and commitment in American life. New York: Harper and Row.

Benjamin, R.S., Carroll, S., Jacobi, M., Krop, C., \& Shires, M. (1993). The redesign of governance in higher education. Santa Monica: Rand, MR 222-1ET.

Berg, B.L. (1995). Qualitative research methods for the social sciences (2nd. ed.). Boston: Allyn and Bacon.

Berson, J. (1998). A study of the effects of a service-learning experience on student success at an urban community college. Unpublished doctoral dissertation, Florida International University, Miami, Florida.

Binkley, N., \& Minnes-Brandes, G. (1995, Summer). Reflection: Meanings and interpretation. Curriculum Inquiry, Vol. 25 (2), 208-210.

Bogdan, R.C., \& Biklen, S.K. (1982). Qualitative research for education : An introduction for theory and methods. Boston: Allyn and Bacon. 
Bogdan,R.C., \& Taylor, S.J. (1975). Introduction to qualitative research methods. New York: Wiley.

Bok, D. (1982). Beyond the ivory tower: Social responsibilities of the modern university. Cambridge, Mass.: Harvard University Press.

Boorstin, D.J. (1983). The discoverers: A history of man's search to know his world and himself. New York: Random House.

Boss, J. A. (1994). The effects of community service work on the moral development of college ethics students. Journal of Moral Education, 23 (2), 183-198.

Boyer, E. L., \& Hechinger, F.M. (1981). Higher learning in the nation's service. Washington, D. C.: Carnegie Foundation for the Advancement of Teaching, ED. 212206.

Boyer, E. L. (1987, October). Service: Linking school to life. Community Education Journal, 7.

Boyer, E. L. (1994, March). The higher education institution of the future. Chronicle of Higher Education, Vol. XI (28), A14.

Boyer, E. L. (1996). The scholarship of engagement. Journal of Public Service and Qutreach, Vol. 1 (1), 11-20.

Boyte, H. C. (1991, June). Community service and civic education. Phi Delta Kappan, Vol. $72(10), 765-767$.

Broward Community College Catalog (1997-98). Mission. 21-22.

Brown, S. \& Knight, P. (1994). Assessing learners in higher education. London: Kogan - Page.

Bumphus, W. G. (1996, August/September). Dare to dream the dream. Community College Journal, Vol. 67 (1), 3.

Chickering, A. W., \& Reisser, L. (1993). Education and Identity, (2nd.ed.). San Francisco: Jossey-Bass.

Cohen, A. M., \& Brawer, F. B. (1982). The American community college. San Francisco: Jossey-Bass.

Cohen, J., \& Kinsey, D. (1994, Winter). 'Doing good' and scholarship : a service-learning study. Journalism Education, 4-14. 
College Preparatory Success Rate Report (1996, December 29). Florida State Board of Community Colleges, Tallahassee, Florida.

Conrad, D.,\& Hedin, D. (1991). School-based community service : what we know from research and theory. Phi Delta Kappan. Vol.72(2), 743-749.

Conrad,D.,\& Hedin, D. (1992). The importance of experiential education on adolescent development. Child and Youth Services. Vol.4, 57-76.

Cove, P. G., \& Love, A.G. (1996). Enhancing student learning : Intellectual, social, and emotional integration. ERIC Digest, ERIC Document Reproduction Service, No. ED 400741.

D'Alemberte, T. S. (1996, Spring). President's Pundit. Voice and Vision of the Florida Campus Compact, Vol. 4 (1), 2.

Denzin, N.K., \& Lincoln, Y.S. (Eds.)(1998). Strategies of qualitative inquiry. Thousand Oaks, California: Sage Publications.

Dewey, J. (1938). Experience and education. New York : Macmillan Publishing Company.

Dewey, J. (1929). The quest for certainty. New York: Minton, Balch Publishers.

Draper, A. S. (1907). The American type of university. Science, Vol.26, 33-43.

Eisner, E. (1991). The enlightened eye. New York: Macmillan Publishing Company.

Eisner, E. (1992,Spring). Objectivity in educational research. Curriculum Inquiry, Vol. $22(1), 9-15$.

Enos, S. L.,\& Troppe, M. L. (1996). Service-learning in the curriculum. In B. Jacoby and Associates. Service-learning in higher education, 156-181. San Francisco: Jossey-Bass Publishers.

Ford, P. L. (Ed.) (1903, vol. 8). The works of Thomas Jefferson. New York: Knickerbocker Press.

Feng, X. (1996, July 15). College preparatory completion rate based on verbal and mathematics deficiencies. (Institutional Research Brief, RR 96-16). Broward Community College, Ft. Lauderdale, Florida. 
Freedman, M. B. (1967). The college experience. San Francisco: Jossey-Bass.

Freire, P.,\& Macedo, D. (1987). Literacy: Reading the word and reading the world. New York: Bergin and Garvey.

Geertz, C. (1983). Local knowledge: Further essays in interpretive anthropolgy. New York: Basic Books.

Giles, D. E.,Jr., (1988). Dewey's theory of experience: Implications for servicelearning. Journal of Cooperative Education. Vol. XXVII (2), 87-90.

Giles, D. E.,Jr., \& Eyler, J. (1994, August). The impact of a college community service laboratory on students' personal, social and cognitive outcomes. Journal of Adolescence, Vol. 17 (4), 327-339.

Glaser, B. \& Strauss, A. (1967). The discovery of grounded theory: Strategies for qualitative research. Chicago: Aldine.

Gleazer, E. J., Jr. (1990). Emergence of the community college as a center for servicelearning. In J.C. Kendall and Associates. Combining service and learning. A resource book for community and public service (Vol. I, 160-162). Raleigh, North Carolina: National Society for Internships and Experiential Education.

Gore, J. S., \& Nelson, H. (1984). How experiential education relates to college goals and objectives. Evaluation and Program Planning, Vol.7, 143-149.

Groennings, S. (1997, Winter). Educated idealism at the University of Utah. Action Reflection. The International Partnership for Service-Learning.

Gruber, H. E., \& Voneche, J. J. (1977). The essential Piaget. New York: Basic Books Inc.

Habermas, Jurgen. (1970). On systematically distorted communication. Inquiry. 13, 360375.

Hammond, C. (1994, Fall). Integrating service and academic study : Faculty motivation and satisfaction in Michigan higher education. The Michigan Journal of Community Service Learning. Vol. 1 (1), 21-28.

Harkavy, I. (1995, June). Summary of workshop presented at the Campus Compact Center. Community Colleges Fourth National Conference. Scottsdale, Arizona. 
Hedin, D. (1989). The power of community service. Proceedings of the Academy of Political Science. 37, 201-213.

Hofstader, R.,\& Smith, W. (Eds.) (1961). American higher education: A documentary history. Chicago: University of Chicago Press.

Honnet, E. P.,\& Poulson, S. J. (1989). Principles of good practice for combining service and learning. The Wingspread Journal. Published by the Johnson Foundation.

James, W. (1920). The letters of William James.Atlantic Monthly. 126(1), 1-15.

Janesick, V. J. (1994). The dance of qualitative research design: Metaphor, methodolatry, and meaning. In N. K. Denzin, \& Y. S. Lincoln (Eds.), Handbook of qualitative research ( pp. 209-219). San Francisco: Sage Publications.

Janesick, V. J. (1998). "Stretching" exercises for qualitative researchers. Thousand Oaks: Sage Publications.

Kendall, J. C.,\& Associates (1990). Combining service and learning: A resource book for community and public service. Raleigh, North Carolina: National Society for Internships and Experiential Education.

Komives, S. R., Woodward, D. B., Jr. and Associates (1996). Student services: A handbook for the profession. San Francisco: Jossey-Bass.

Kvale, S. (1996). InterViews. Thousand Oaks: Sage Publications.

Lather, Patti. (1988). Feminist perspectives on empowering research methodologies. Women's Studies International Forum. 11(6), 569-581.

Lempert, D. ( March 26, 1998). Service-learning network, email, <lemp @ gwis 2. circ. gwu. edu>

Levine, M. A. (1994, Fall). Seven steps to getting faculty involved in service-learning: How a traditional faculty member came to teach a course on "volunteerism, community, and citizenship." The Michigan Journal of Community Service Learning. Vol. 1(1), 36-47.

Lincoln, Y. S., \& Guba, E. G. (1985). Naturalistic inquiry. Beverly Hills, California: Sage Publications.

Madison, P. (1969). Personality development in college. Reading, Mass.: AddsionWesley. 
Markus, G. B., Howard, J. P. F.,\& King, D. C. (1993, Winter). Integrating communityservice and classroom instruction enhances learning: Results from an experiment.Educational Evaluation and Policy Analysis, Vol.15 (4), 410-419.

Marshall, C., \& Rossman, G.B. (1995). Designing qualitative research (2nd ed.). Newbury Park, California: Sage Publications.

McCluskey-Fawcett, K.,\& Green,P. (1992). Using community service to teach developmental psychology. Teaching Psychology. 19, 150-152.

Miles, M. B., \& Huberman, A. M. (1994). Qualitative data analysis: an expanded sourcebook. London: Sage Publications.

Miller, J. (1994, Fall). Linking traditional and service-learning courses: Outcome evaluations utilizing two pedagogically distinct models. Michigan Journal of Community Service Learning. Vol.1(1), 29-36.

Minnich, E. K. (1988, Summer). Some reflections on civic education and the curriculum. In S. W. Morse. Renewing civic capacity: Preparing college students for service and citizenship. (ERIC Digest, ERIC Document Reproduction Service No. ED 321 104).

Moffatt, M. (1988). Coming of age in New Jersey: College and American culture. New Brunswick, New Jersey: Rutgers University Press.

Myers-Lipton, S. J. (1994). The effects of service-learning on college students' attitudes toward civic responsibility, international understanding, and racial prejudice. [CD-ROM]. Abstract from ProQuest file: Dissertation Abstracts Item: 9524331.

National Institute of Education. (1984, October). Involvement in learning : Realizing the potential in American higher education. Washington, D.C.: U. S. Government Printing Office.

National News Service. (March 23, 1998). President's national and community service amendment act of 1998. Delivered by Hillary R. Clinton, Issue \# 50 (http:// www. nationalservice. org ).

Nettles, M. T. (1995). The emerging national policy agenda on higher education assessment: A wake-up call. The Review of Higher Education, Vol. 18, 293-313.

Oldenberg, D. (1990, February). What's in store for the 1990's? Upside, downside and in between. Washington Post, p.C5. 
Ostrow, J. M. (1994). Sticking to our principles in research. NSEE Quarterly, Vol.19 (3), 4-5, 28-29.

Pascarella, E. T.,\& Terenzini, P. T. (1991). How college affects students. San Francisco: Jossey-Bass.

Pasternak, B. (1958). Dr. Zhivago. Pantheon Press: London.

Patton, M. Q. (1987). How to use qualitative methods in evaluation. Newbury Park, California: Sage Publications.

Poirier, R. (1992). Poetry and pragmatism. Cambridge,Massachusetts: Harvard University Press.

Punch, M. (1986). Politics and ethics of fieldwork. Beverly Hills, California: Sage Publications.

Rama, D. V.,\& Zlotkowski, E. (1996, Summer). Service-learning and business education: Creating conceptual bridges. NSEE Quarterly, 11-12, 26-27.

Reason, P. (1998). Three approaches to participative inquiry. In N.K. Denzin,\& Y.S. Lincoln (Eds.). Strategies of qualitative inquiry (pp.261-291). Thousand Oaks, California: Sage Publications.

Resnick, L. B.,\& Klopfer, C. E. (1989). Toward the thinking curriculum: Current cognitive research. Alexandria, Virginia: ASCD.

Rifkin, J. (1996, April/May). Preparing the next generation of students for the civil society. Community College Journal, 20-23.

Rossi, P. (1994). The war between the quals and the quants: Is a lasting peace possible? In C. S. Reichart, \& Rallis, S. F. (Eds.). The qualitative - quantitative debate: New perspectives and new directions for program evaluation No. 61 . San Francisco: Jossey-Bass.

Sax, L. J., \& Astin, A. W. (1997, Summer). The benefits of service: Evidence from undergraduates. Educational Record,Vol. 78 (3-4), No. 03435061, 25-32.

Schroeder, C. C. (1993, September/October). New students - new learning styles. Change, 21-26.

Seidman, I. E. (1991). Interviewing as qualitative research. New York: Teacher's College Press. 
Sigmon, R. (Ed.) (1987). Community service, civic arts, voluntary action and service-learning. Occasional Paper \#81, NSEE Publication.

Smith, M. W. (1994,Fall). Community service-learning: Striking the chord of citizenship. The Michigan Journal of Community Service Learning, Vol.1(1), 37-43.

Spradley, J. (1979). The ethnographic interview. New York: Holt, Rinehart and Winston.

Stanton, T. K. (1994, Fall). The experience of faculty participants in an instructional development seminar on service-learning. The Michigan Journal of Community Service Learning. Vol.1(1), 17-20.

Taba, H. (1962). Curriculum development theory and practice. New York: San Francisco Press.

Tyler, R. (1949). Basic principles of curriculum. Chicago: The University of Chicago Press.

Wade, R. C. (1994, Fall ). A century of service-learning: Can we get there from here? NSEE Quarterly, 6-7, 26.

Walker, S.,\& Nozaki, R. (Eds.) (1991). Community and volunteer service: A resource guide for community colleges. Campus Compact Publication.

Weaver, R. A., McElhinney, J. H., \& Allen, J. K. (1983). Evaluating student volunteers and service-learning programs: A casebook for practitioners. Washington, D.C.: National Center for Service-Learning, 109-117.

Wilson, E. K. (1966). The entering student: Attributes and agents of change. In T. Newcomb and E. Wilson (Eds.). College peer groups, 71-106. Chicago: Aldine.

Wisnewski, J. J. (March 25, 1997). A student's reflections on service. American Association of Community Colleges Home Page, Community College Times, (http://www.aacc.nche.edu/commun/times/opinion/032597 - 1.htm).

Wolcott, H. F. (1994). Transforming qualitative data. Thousand Oaks, California: Sage Publications.

Wolcott, H. F. (1995). The art of fieldwork. Walnut Creek, California: Alta Mira Press. 
Appendix A

Informed Consent Letter

Sample

Building 07, Room 205

Broward Community College

4301 SW Davie Road

Ft. Lauderdale, Florida 33314

June 26, 1998

Ms. Janet Doolittle (fictitious)

402 SW First Street

Plantation, Florida 33321

Dear Ms. Doolittle,

This letter is a follow-up to our telephone conversation. Its purpose is to clearly state that the interview sessions that we will plan are to get your perspectives and to reconstruct the details of your experiences as a participant in a service-learning course at Broward Community College. This information will be used as the major part of a doctoral dissertation that I am writing as partial fulfillment for an Ed. D degree at Florida International University (Broward Program) under the direction of Dr. Valerie J. Janesick, Director of the Broward Doctoral Program and my committee chairperson.

Your name was chosen from a list of all the students at Central Campus who took part in a service-learning course. All interviews will take place in a safe space to be designated by you and will last approximately one hour. A pseudonym will be substituted for your first name, if you so wish, (no family name will be reported)and every step will be taken to disguise your identity in any and all material from this dissertation (in part or in whole) that may be published in the future. The interview sessions will be taped for your protection, so that nothing reported is taken out of context or misquoted. Since I will be transcribing from the tapes, no one else will have access to them.

It is your right to withdraw from the interview study at any time during the study or up until one week after the interviews have been completed. When we review the information from the interviews, you will have the right to withhold any of the interview data that you choose. 
I will be interpreting the information we share based on sound, professional principles which will not compromise your dignity as a participant in this study. I am fully responsible for anything that is included in this study.

It is very important that we understand the value of service-learning from your perspective; therefore, I hope that you decide to participate in this study. We need to hear student voices. What you have to say is significant.

If you agree to take part in this timely study, please circle the word "agree" and sign this letter on the designated line below and return it in the enclosed stamped envelope within five days. If you decide not to take part in this study, please circle "do not agree," sign your name, and return the letter.

Thank you for your cooperation in this matter.

Sincerely yours,

Richard Appelbaum

I agree / do not agree to participate in this study.

Janet Doolittle 
Appendix B

\section{Release Form}

I have reviewed the transcripts of my interview sessions with Mr. Appelbaum and agree to allow him to use any and all of the information for the purpose of this study and any project that may come out of this study including, but not limited to, professional presentations, journal articles, and professional books related to service-learning. We have discussed the meanings that have arisen from my interview statements and their implications. I am very well aware of these, and I agree to allow Mr. Appelbaum to use them in any professional manner that he sees fit. Any reservations that I may have, or statements from the interview sessions that, at this time, I wish to delete, I have written below. From this time on, I am aware that I can no longer make any deletions or changes in any of the statements I have made.

signature

date 
I, , give Richard Appelbaum the right to see, read, and copy any and all of my journal entries related to my service-learning experience at Broward Community College. I understand that this is for the sole purpose of analyzing this information for the purpose of this specific study entitled AN INTERVIEW STUDY OF COMMUNITY COLLEGESTUDENT PERSPECTIVES ON SERVICE-LEARNING, and for no other project. 


\section{Appendix D}

\section{Interview Protocol}

For the purpose of the interview sessions, a semistructured interview protocol was developed based on findings from the pilot study. More specifically, questions were prepared with the idea in mind that the respondents could and would develop a line of conversation in greater depth relating to the nature of their own role in the service-learning experience. The researcher will be looking for categories to emerge as he familiarizes himself with the empirical world of the interviewees. The interview will be reported by making use of detailed description using direct quotes and narrative vignettes, the reflections of participants, and observations that supplement and add meaning to the information. Marshall and Rossman (1995) tell us that in-depth interviews are exploratory in nature. They seek to discover general topics with regard to the participant, as they emerge from her/his perspective of meaning. From these topics, the initial interpretations of the data are continually tested and, if needed, reformulated on the basis of ensuing evidence (Bogdan and Biklen, 1992).

At the beginning of each interview session, I will remind each participant that the purpose of the interview is to gain insight into the service-learning experience from her/his own unique perspective.

\section{First Interview Protocol}

The first interview serves as an ice-breaker and determines the value of each prospective participant as an interview subject. After small talk and attempting to create a trustworthy atmosphere the following questions will be asked.

1. What motivated you to take part in a service-learning experience?

2. What were your expectations of doing service-learning? 
3. Tell me about your service-learning experience. Where you volunteered and what you did.

Second Interview Protocol

1. In what ways did service-learning give you a better understanding of your classwork?

2. What did your classwork teach you about everyday life?

3. How did service-learning change your attitude toward academic studies?

4. Let's talk a little about how your service-learning experience helped you learn more about yourself, your personal strengths and weaknesses.

5. As a result of taking part in service-learning how have your feelings about your connections to your community been enhanced or changed?

6. How did the service-learning experience affect your educational goals and career plans?

Third Interview Protocol

1. Let's talk about anything you would like to add or delete from our last interview session.

2. What are your reflections on your service-learning experience?

3. What advice would you give to a student just starting a service-learning experience?

4. Is there anything you would like to say to your instructor or administrators here at the college about service-learning? 


\section{Appendix E}

Interview Session \#1

Sample from Transcript

Susan (referred to as 1)

Interviewer (referred to as A)

Wednesday, October 14,1998

9:45 a.m. - 10:23 a.m.

Library lounge, second floor

BCC Central

The first approximately five minutes were used for introductions and pleasantries. I then geared the talk to focus on generalities about service-learning at the college and then more specifically about the participant.

A: Susan, what motivated you to take part in a service-learning experience, especially since you tell me that it was not mandatory?

1: (short silence followed by nervous laugh) You want the truth?

A: Sure, I can handle it.

1: Well, the professor talked to the class about his involvement in volunteer work in the community and told us that if any of us did volunteer work during the semester, we would get extra-credit. I don't pass up on extra-credit.

A: How did the instructor present service-learning to the class apart from talking about his opinion of volunteerism?

1: Oh well, let me think. (pause). Well, he just said that we could either find a place to volunteer on our own or there was a volunteer fair coming up where we could get more information. Then, a few days later someone came to class with forms to fill out that we had to bring to the place where we were going to volunteer.

A: What did this person tell the class about service-learning?

1: Nothing I can remember. I think she said, yeah, it was a lady. Anyway, she said that the professor told us all we need to know. She reminded us that we had to keep something like a diary just to give an idea of the dates and what we did. But, when another student asked what she meant by service-learning, she said it was like the professor said, volunteer work. It would help us understand civic responsibility and we'd get extra-credit. Twelve and a half points for doing volunteer work and another twelve and a half points if we handed in a journal. She gave us some papers, but she didn't say 
anything about them. I think most of us put them away and never looked at them again, except for the agreement that we had to get signed and had to be returned. It seemed worthwhile, so I decided what the hay, I might as well do it.

A: What were your expectations of doing this service in the community?

1: Well, I wanted to volunteer in a school, especially the school where my kids attend. I had helped out there a little in the past. I didn't really have any expectations. (laugh and blush) I just wanted to help out.

A: Susan, tell me a little about your service-learning experience.

1: Like from day one?

A: If it'll help you remember.

1: I went to the school to pick up my kids, but I got there a little earlier so I could go to the office and talk to the assistant principal. I told her about my class and the volunteer work for extra credit, and she said that they need a volunteer in the health office and doing other things around the school as needed. I started, let's see, that was a Thursday. I started on Monday after classes at BCC. Cooper City Elementary School. The school my kids go to.

\section{A: What were your duties?}

1: Mainly I recorded the names of kids who came to the clinic because they didn't feel well. I had them lay down and I called someone to come get them. Most of the kids are nice and just want a little attention when they're not feeling too well. So, I would say something nice and smile and maybe put a wet, cool wash cloth on their foreheads if they had a headache or some such thing. I could put a band-aid on a cut, or if a student needed prescription medicine, I could administer it. It was kept locked, so no one else could get to it. That was basically it.

Susan had to prepare for her next class, so we said our goodbyes and arranged to meet on the 21 st in my office at the same time. Before she left, she asked me to explain a little about why I used the term "service-learning" instead of "volunteer." I briefly explained the concept behind service-learning. 


\section{Interview Session \#2}

Wednesday,October 21,1998

my office, 2-113

Susan arrived five minutes before our interview session was scheduled to begin. After some small talk about the weather and how her courses were coming along, we began the interview.

A: Susan, the last time we talked, you explained what you were doing at the school. I told you a little about what service-learning is. From what I told you, let's talk a little, or as much as you care to, about how this service tied in with your classwork, if it gave you a better understanding of what you were learning.

1: (long pause) I didn't see any connection. I mean this was a history class; what could it have to do with my volunteering in a school?

A: How did your instructor help you see connections?

1: He didn't. We never discussed our volunteer work. It was a history class and he taught history.

A: Susan, did you ever get into groups to discuss your reflective journal entries with other students?

1: We never did that. We were told to hand in our diaries at the end of the semester.

A: Let's talk about how things were going at the school you were volunteering at.

1: Besides working at the health office, I was asked to help with a fair, kind of like an international fair. I guess they called it a carnival. I called parents for help. We were supposed to help the kids do things to represent the countries that their families came from and have games and contests. I helped the kids from Spanish speaking countries because I took Spanish in school and I was in that Latin American history class at BCC.

A: Susan, you were taking a Latin American history class and helping Hispanic students prepare displays. Do you see a connection here?

1: Oh,wow! I never thought of that. What I was learning in class helped me get along with these students. It helped me think of themes for the displays. I even told them about a game we had read about in class that the Aztec children used to play, and we tried to reproduce it for the fair. The kids liked it.

A: Did you share this with your instructor? 
1: No. Because we never talked about our volunteer work. I thought it would interfere with class. I put it in my diary.

A: And when your teacher read your journal, did he comment on this or any other entries?

1: No. We handed in the journals during the last week of class, and we never heard anything about them after that.

A: Susan, in what ways do you feel that experiences like this gave you a better understanding of your classwork?

1: Well, when we got to the part where we learned about some of the countries, I actually had met students whose families came from those countries.(Susan's eyes opened wide) Yeah, you know there is a connection between what I was learning and the volunteer work I was doing. There was. Gosh, I never realized it.

A: How did your coursework, since it was Latin American history, relate to the various Hispanic groups that exist here in our own community? (Susan looked puzzled,so I decided to rephrase the question) Service-learning is concerned with making classwork practical and meaningful to show relationships to everyday life in our community. Did the fact that there is a large and diverse Hispanic population in Broward County come into discussion in your class?

1: Umh, I kinda think I remember the professor asking if anyone in the class was from Latin America. Two or three students raised their hands.

A: And how did the instructor make use of these students?

1: Oh, I just think he made a joke of it. Like they must be taking the class for an easy grade since they should know their own histories.

A: How did the service experience affect your educational goals, your career plans?

1: Well, I thought about becoming a teacher, an elementary teacher, but I wasn't sure. The volunteer work made me see that I really like being with kids, and that's what I want to do. It helped me make up my mind.

A: That's good, Susan. Now, could we talk about how service-learning helped you learn more about yourself, your personal strengths and weaknesses if you feel it did.

1: Well, it made me see that I had the ability to relate well to children who weren't my own. That I could enjoy helping them learn. One day I was in a classroom when the teacher was called out, and one little boy started to act up. 
A: What do you mean by "act up?"

1: He got out of his seat, it was during quiet reading time, and he started to pull books out of other students' hands. I walked over to him and firmly took his arm and asked him to come with me. I sat him by me and had him start reading so that I could hear him. I told him that he reads well. He just kind of looked at me and then smiled. I told the teacher after class what happened and she told me that I handled it well. That made me feel great. I felt like, "Hey, I can deal with these kids."

A: So, you learned something valuable about yourself.

1: Yeah. What a good feeling. I couldn't wait to get home and share that with my husband. He always says that I'm easy with kids, my own and others. He says I let them walk all over me. I really want to be a teacher. Now, I have to do well in my classes, don't I?

A: You have a clear goal now.

1: Yeah, I do.

A: Susan, in what ways have your connections to or awareness of your community and its problems changed as a result of your service-learning experience?

1: (pause and rapid eye movement) Gosh, I'm trying to think about that. Oh, I know. One thing, I've gotten active with the school's PTA regarding having a nurse in the schools. From working in the clinic I saw that sometimes a student is really sick and there's no trained nurse there. I plan to help with a petition at our school. Also, the class sizes are so big. It's hard for a teacher to deal with so many students at one time. It's a big problem. We're planning on trying to do something about that. Years ago, I took a few practical nurse classes. That'll really help me in the classroom.

\section{Interview \#3}

Monday, November 23,1998

my office, $2-113$

8:30 a.m.-9:12 a.m.

A: Susan, since we last talked, can you think of anything you'd like to add to or delete from what we've talked about so far?

1: Wow. (a long pause) I don't think so. ( a nervous laugh) I think I meant everything I said.

A: What are your reflections on your service-learning experience? 
1: My reflections. You mean now that I think about it?

A: ( a positive shake of the head)

1: I guess that it meant more to me than I originally thought.

A: Can you explain your comment?

1: Well, I wish that we had made this more a part of the class. I mean to talk about it with the other students. I'm interested now in what they did, what kind of experiences they had. I have no idea what others did. I wish I had shared my Latin America project with the class, you know with those who did service-learning. I guess I did take more of an interest in class after I did that project with the kids. I never thought of it before. I guess it did help me put pieces together.

A: Considering your experience, what would you say to a student who has just been given the opportunity to do service-learning?

1: I would say that it's a valuable experience. I would use myself as an example. It helped me see my goals. It's fun to help others and learn something about yourself. I see now that it can make you more serious about studying. People have to get involved. Look how it made me aware of the need for nurses in the schools. I knew about class sizes from TV and articles in magazines, but now I experienced it first hand. It's a lot different from just hearing about it or reading about it. You know, it meant a lot to my kids too. Working in the school they attend. I think they were proud of the fact.

\section{A: Any final thoughts, Susan?}

1: I'm more determined than ever to finish college and become a teacher. I see now the need to be involved in my community. There are problems, and I have to volunteer to help solve them. I can pass this on to my children and, hopefully, my students some day. I've seen that I can make a difference. I wish I had the chance to share this with the people in my class. You know, only six or seven of us did service-learning. The others had no idea what we were doing. (laugh) Well, none of us knew, those doing service, what anyone else was doing. Service-learning should have been made more a part of the class. We could have shared so much. Maybe service should be a requirement in some college courses. I don't know if you can force anyone to do it, but maybe it should be stressed more. It's very important. But, students have to make their own decisions whether to do it. (pause) That's it. I can't think of anything else.

A: Thank you, Susan, for taking time to share these experiences with me. I'll be in touch with you as soon as I transcribe our conversations so that we can revisit them and discuss them. 
Interview Session \#2

Sample from Transcript

\author{
Ellen (referred to as \#4) \\ Interviewer (referred to as A) \\ Friday, October 23,1998 \\ 1:30 p.m.- 2:50 p.m. \\ Office- Building 02-113 \\ BCC Central
}

Ellen arrived five minutes ahead of time. Immediately, she started talking about a problem with math that was annoying her. I let her talk for approximately six minutes and then turned to her service-learning experience.

A: Ellen, how did service-learning tie in with your class work?

4: (Ellen repeats the question in a low voice almost to herself) It seemed to me that everything that we did in class, I mean the writings and the group work, discussions was all related, or made to relate to our service work. All the papers that we wrote were based on what we were doing out in the community. Like one paper I wrote that was a description paper. Well, I described the people I was working with. There was one priest that was heading the program, Father Sean; I grew very close to him because of his personality and his charisma, so it was great fun describing him. The instructor loved what I wrote. (A laugh) I mean nobody ever liked the way I wrote. That was good, really good.

A: So your instructor really made a connection between class work and your servicelearning work in the community.

4: Oh, definitely. Even the students who didn't do service-learning were caught up in what we were doing. It really made the classwork interesting. I didn't mind correcting, or editing my papers because they were so meaningful to me. So much better than, let's see, 
like writing a paper on describing a building on campus. Who cares about a building on campus? How can you write an interesting paper on something you don't care about? Yeah, everything we learned in English was connected somehow to our community experience.

A: Let's talk a little about your service-learning experience. What you did and whatever else you want to say about it.

4: My work dealt with a hunger program at a church in Hollywood. I helped raise money at a church fair, I led a food collection drive and helped with the pantry, I helped get parishoners involved, and I helped some of the children of homeless people with their homework. I spent more hours doing this than I was required to do, but it became part of my life. It meant a lot to me. I was able to put human faces on these homeless people. Before that experience, the homeless were like one big glob to me; now I saw them as individuals. Most of them didn't want to be in that situation. The kids,especially, seemed really affected by being homeless. They were quiet and sad. It really got to me. I can imagine what it was like for them when other kids went home after school, and they had no home to go to.(Wipes away tears) God, it's hard to talk about. But, I wrote papers about it, and I discussed it in my group, and I talked about it to the whole class during open discussion. You know, two kids in class even came up to me and asked if more help was needed at the church. I said, "Sure." I don't remember ever seeing them there though.

\section{A: How did you use your journal?}

4: We were shown how to keep a reflective journal by the instructor and Justine from the service-learning office. We used the journal entries to refresh our minds when we had to write papers and for our discussion groups. The instructor checked our journals, but I think it was more for English, you know, how we were using grammar and punctuation and spelling, but he did comment on what we wrote, as well.

\section{A: You mean the content?}

4: Yeah, that's what I mean.

A: In what ways do you feel service-learning helped you do better in class than you would have done otherwise?

4: Oh well. It made a big difference. Like I said, it made the course interesting. I was eager to do the work, write the papers and take part in discussion. I'm sure I did better because of it. I'm sure of that. No doubt in my mind. 
A: How did the service-learning experience help you decide on a career goal, if it did?

4: Before that I knew that I wanted to go to college, but I wasn't really sure what I wanted to do with an education, but after talking to the instructor about my illnesses, what I told you about the last time, he mentioned various careers for me to look in to. One was counseling. After a while, I decided that I would like to counsel disabled students at this level, the community college. Not many people really understand us. I don't think a person can imagine what it's like, so they tend to treat us like those poor things, smile at us and talk softly. We're not brain-damaged; we're disabled. Treat us like humans.

A: So, for this reason you feel that you could more realistically work with disabled students?

4: Sure. I'm one of them. I understand them, and I also know when they're looking for sympathy, out to take the system for all it's worth. Pull the wool over people's eyes.

A: It sounds to me like you understand yourself really well.

4: I have a confidence in myself now that I never had before.

A: Do you credit service-learning for this?

4: I credit the way the instructor taught the course. He made me feel good about being me. Through my writing I learned a lot about who I am, and what I believe. He reinforced that by the comments he made on my papers. I guess service-learning was the tool. If not for that instructor and service-learning, I'm not sure I would still be here. I like servicelearning, but it takes the right kind of instructor. I mean, I look at some of my instructors here (Ellen shakes her head slowly and negatively) they'd never be able to do it. They don't have any personality. Not the kind to do service-learning. 
My goal today is to get into the servicelearning process that Nestor experienced in class and out in the field. This session, I hope, will give me the rich data that I'm after.
Friday, October 20,1998

2nd Interview Session with Nestor

Office - Building 02-113

5 p.m. - 6:40 p.m.

It's raining quite hard, so Nestor was approximately ten minutes late. I had called him last night to remind him, and he said he had it written down, but I was still concerned. He is soaking wet, so I sent him to the men's room to dry off as much as possible.

This is the second interview, but I still feel like I need an ice-breaker with him. He shows very little emotion.

Nestor still insists that what he did had nothing to do with his class work. He doesn't call it service-learning. He doesn't use the term at all. This has me concerned.

He sits very still and straight almost like he's being interrogated. Maybe too many spy dramas. I ask him if he's comfortable. He insists he is. I'm going to stop the interview for a few minutes and talk to him about his out-of-school interests. He's interested in soccer. When we talked about it, he began to lighten up, moved in his seat, and crossed his legs. As soon as we started talking about service-learning, Nestor uncrossed his legs, moved back in his seat, and sat straight again. Why??? 
I've decided to ask him in a round-about way if talking about service-learning bothers him.

It does! He's not familiar with the concept of service-learning and he admits to feeling uncomfortable. Since it's evident that he didn't have a servicelearning experience, he's uncomfortable with the terminology. Finally, we're getting somewhere. This is like detective work.

Now that Nestor has opened up about his discomfort with service-learning, I feel more comfortable about how to approach him in relation to this topic.

Today, Nestor shared some solid data that will be useful.

According to the O.V.A.L. Office, Nestor has had a valid service-learning experience. I've got to find out why they believe this. What are they basing it on ?

I saw Nestor's journal. It's a few pages of handwritten notes, and there is no reflection evident. What's going on here?

Where do I dig and how far do I dig without stepping on toes? This doesn't involve ethics in dealing with participants but with the institution, the college and the people in charge of service-learning. Bureaucracy. I've got to figure out how to go about this very diplomatically. 
Unbelievable, but Nestor is sharing with me outcomes that could be identified with a service-learning experience.

Social justice, career goals, awareness of community problems.

It annoys me to think that if the student services office and the instructor had really implemented service-learning, Nestor could have benefitted so much more. Darn it! 


\section{Browari) Community Collegl:}

OrFice or rill:

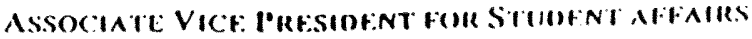

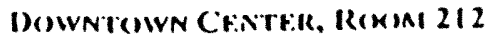

Ti:1:: 954.761 .7495

ibcrsonsibrewardecenus

Fिx: 954.761 .7579

To: $\quad$ BCC Faculty

firom: Judith Berson, Ed.D

Dalc:

Augusi 10, 1998

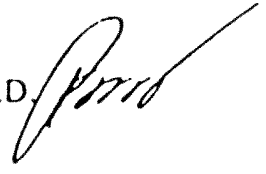

Subject: BCC Service-Lcaming On-line

I am pleased to announce the creation of a new tool to assist BCC. faculty and sludents in lcaming about scrvice-learning. You can access BCC's scrvice-lcaming web site through fs.broward.cc.n.us/dtc/sa_articles.html. Once there, be sure to bookmark the site so you can retum easily. You can also access it by going through the $\mathrm{BCC}$ home page at www.broward.cc.n.us going into College Information, then Student Services (under Students) and then Service-Leaming.

There is a Student Afrairs contact person on each campus to assist faculty and students in arranging community service and voluntcer activities. Please feel free to call:

$\begin{array}{lll}\text { Central } & \text { Liz Atchison, Student Life } & 475.2325 \\ \text { North } & \text { Heidi Schivartz, Career Center } & 973.2355 \\ \text { South } & \text { Charlie Lyle, Student Life } & 968.8973 \\ \text { DTC } & \text { Lamar Spaulding, Student Life Coordinator } & 761.7321\end{array}$

In order to assist us in providing current information, I am requesting that you complete the questions at the bottom of this page. Please list all courses that you are teaching this Fall that will include a service component.

Future plans include modifying course descriptions in the college catalog to indicate courses that include service-learning options.

$x$

Your Name Dept Campus

Phone Fax E-mail

List all of your courses that will include a service-learning option (feel free to use reverse):

\begin{tabular}{|l|c|}
\hline Course Number & Course Name \\
\hline & \\
\hline & \\
\hline & \\
\hline
\end{tabular}

Return completed form to:

Dr. Judith Berson. DTC. 225 East Las Olas Blvd. Room 212, Fi. Laud, FL 33301 


\section{Student Affairs BCC Service-Learning Online}

Service-Learning at BCC

Articles by Dr. Judith S. Berson

Community College: Service-Learning Information

National Campus Compact

Florida Campus Compact

Service-Learning on the Internet

Home / Professional Resources / Schedule / Campus Maps / Libraries

$<! C^{-} \quad / /$ This is a little e automated 


\section{College Mission}

The mission of Broward Community College is to provide all segments of the community with academic and technical educational opportunities through both traditional and progressive programs. Of primary importance in delivering these educational programs is the commitment to quality instruction delivered by a dedicated faculty engaged in continued professional growth.

As it fulfills its mission, the College is committed to responding to the cultural diversity of Broward County as the area expands. In support of its open-door policy, the College provides a variety of delivery systems and instructional modes to enable students to prepare for the future in accordance with their own individual abilities, noeds, and interests. The College is also committod to providing spocial academic support services to the disabled. In its role as an institution of higher education and in its efforts to be a premiere teaching institution. Broward Community College is dodicated to fulfilling the following major functions:

1. To serve as an entry-point for baccalaureate degree programs by providing the first two years of a four year curriculum through a program of general education that stresses historical, social, ethical, and global perspectives; communication and computation skills, the sciences, an approciation of the humanities, and physical fitness.

2. To prepare individuals for employment through a variety of specific programs in the general areas of business and management, the heatth sciences, the engineering and industrial tochnologies, and public service.

3. To provide economic development and continuing education activities to meet the needs of business, industry, the professions, and govemment. To enhance employee skills while also serving individuals seeking to maintain their competencies, upgrade their skills, change occupations, or enrich their lives through lifelong leaming programs.

4. To provide college-preparatory instruction for those students who need to enhance their basic academic skills prior to attempting college-level work.

5. To serve as a cultural center for Broward County by providing a wide variety of quality visual and performing arts programs and activities which oducate, entertain, enrich lives, and elevate the human sprint.

6. To provide international and intercultural educational experiences to help students develop perspectives that will enable them to function effectively in a multicultural environment and in an interdependent world. To pursue linkages with educational institutions and agencies in other countries in order to provide for an academic interchange and to assist each other in achieving . educational objectives for the improvement of higher education on a global scale.

7. To provide current students a full range of student development and academic support services which are proactively available both on the College campuses and in the Broward County 
community. To provide the opportunity for students to contribute to the well-being of others through student service leaming programs that are part of their higher education experience.

8. To engage in programs and activities that will expand the opportunity for higher education to prospective students throughout the entire Broward County community. Such programs may be offered in conjunction with the School Board of Broward County, the State University Systern, the city/county government, and various community agencies.

|BCCHornc|

Wehmiasier

Sanford Langbart

Broward Communiry College

Last update: Nov 16. 1998 
Service-Learning at $\mathrm{BCC}$

\section{STUDENT COMMUNITY SERVICE ACTIVITES}

A Broward Community College student majoring in social work spent working with homeless children who have suffered physical, sexual and verbal abuse from those they trusted. He worked hard to show the youngsters that they could begin to trust adults once again. The student was participating in Students Offering Service (S.O.S.), a program designed to increase the retention of BCC's multi-ethric, multi-national student body.

For the past several years, $\mathrm{BCC}$ has worked toward institutionalizing student community service through the implementation of various programs like S.O.S. Other such programs include Challenge to Youth, which pairs BCC student mentors with first-time juvenile offenders; Transitional Insights, which matches BCC students of high academic standing with learning disabled high school seniors who want to go to college; and Volunteers In Action, a volunteer program that places more than 200 BCC students in community service positions with various social service agencies.

Campus organizations such as PTK, F-Troop, DECA and others also involve students in volunteer service activities. Through these programs, BCC has established links in the community, fostering support for each new volunteer effort. an important link has been established with Volunteer Broward, a United Way member agency that recruits and refers volunteers to more than 400 non-profit agencies in Broward County. The BCC mission statement now includes a section on service-learning: "to provide the opportunity for students to contribute to the well-being of others through student service-leaming programs that are a part of their higher education experience."

Our next step was to establish Community Connection, dedicated to assisting interested faculty to incorporate service-learning components into their course work by providing. training opportunities and developing this faculty manual. A well-managed

service-leaming experience allows student to more accurately identify social problems, empathize with the agencies' clientele, and effectively satisfy the demand for community service. The College is implementing a co-curricular transcript to assist students in documenting their out-of-class experience.

BCC's President, Willis Holcombe, is a member of Campus Compact, a consortium of colleges committed to service-leaming programs. His membership validates BCC's commitment to the concept of providing student community service experiences for its students.

For additional information contact: 
Dr Judith S Berson

Assoc. Vice President for Student Affairs

Broward Community College

$225 \mathrm{E}$. Las Olas Boulevard

Ft. Lauderdale, FL 33301

954.761.7495 FAX: 954.761 .7579

\section{What is Community Service?}

When people hear the term "community service," a number of images may come to mind. Some have come to associate community service with the work citizens convicted of crimes are forced to do by judges or parole officers, to pay off their debt to society. Others may picture recently graduated law or medical students sent off to needful areas to work off professional school loan debts. These pictures convey a "forced" and somewhat negative image of "community service," one distinct from the image of "volunteerism" or "philanthropy."

As those in the growing community service movement use the term, however, community service refers to unpaid work that everyone can do to improve the quality of life of those being served, of those serving, and ultimately of the community as a whole. The purpose of community service is not only to help others in need, but to engender in those who serve a sense of social responsibility and commitment to the communities in which they live. While those of us who promote community service may share with the volunteer movement the desire to strengthen altruism, philanthropy, and individual self-reliance, our primary concern is with attacking the problem of civic apathy and lack of attention to the public or common good while also performing activities that serve community needs.

\section{What is Service-Leaming?}

Service-Learning refers to the integration of community service into an organized setting where the servers reflect upon the meaning of their service. The idea behind service-leaming is that by combining the service with a reflective educational structure, powerful benefits that go beyond what either service or learning can offer separately will be created. More specifically, by combining service and learning, individuals who perform the services will be able to see the connection between their work and the underlying values and issues behind the social problem being addressed. Where servers use experience in the community as a basis for critical reflection, they can better examine. democratic communities and the role of the citizens in them. They can develop a habit of critical reflection on their experiences enabling them to learn more throughout life. Combining service and learning can cause citizens from different backgrounds or settings to come together to do common work, and through reflection, learn more about each other and respect each other's cultural differences. 
September 23, 1998

Dear BCC Faculty Member:

It is with great enthusiasm that we introduce you to Service-Learning and co-curricular credit through The O.V.A.L. Office, (The Office of Volunteerism and Leadership), a Student Life program, here at Broward Community College.

As you may already know, The O.V.A.L. Office serves as the college-pide clearinghouse for volunteer and Service-Learning programs. Service-Learning is one of many programs that help promote BCC's national reputation as a leading urban, comprehensive community college serving the diverse higher oducation needs of Broward County.

Service-Learning refers to the integration of community service into course curriculum. Students relate the meaning of their service to parallel classroom learning through journalizing or group reflection. The idea behind service-learning is that by combining the service with a refloctive oducational structure, powerful benefits that go beyond what either service or learning can offer separately will be created.

We are elated to announce that BCC is one of the first community colleges in Florida to establish an optional co-curricular transcript program, that includes a student's extracurricular activities, such as Service-Learning, on their college transcript. This program was created to assist students secking admission to another university, as well as, those searching for jobs.

We are eager to hear your comments regarding Service-Leaming and the information included with this letter. We know that you will be as excited as we are about this program and we look forward to speaking with you personally.

Sincerety,

Liz Atchison

Student Life Coordinator 


\section{The O.V.A.L. Office \\ Office of Voluntecrism And Leadership \\ Service Learning \\ Broward Community College}

1. Are you aware of the concept of service-leaming?

2. Do you currently utilize service-learning in your courses?

3. Would you be willing to incorporate service-learning in your class?

4. How would you like to incorporate service-learning in your class?

5. Do you know how to incorporate service-learning into your grading system?

6. Do you know other instructors who integrate service-learning and academic study? 


\section{Types of Service-Learning Experiences}

Onc-time and Short-Term Service-Learning Experiences

A way to introduce students to service is through well-planned and implemented onetime and short-term experiences. Students take their first steps into the communities around their campus through such activities as spending an afternoon in a neighborhood cleanup project, voluntecring to distribute food or clothing at a local shelter,serving food to older adults, participating in a cancer phone-a-thon, etc. Carefully planned reflection ship be included in preservice, in-service and post-service activities to raise students" level of awareness about service, increase potential for learning and create positive experiences that lead to further involvement in service-leaming.

Ongoing Cocurricular Service-Learning Fraternity and sorority philanthropic activities, campus ministries, and other student organizations regularly participate in service. Servico-learaing outside the classroom often occurs haphazardly, and the quality of learning is suspect due to the little or no structured refloction.

\section{Service-Learning in the Curriculum}

Courses that include service-learning encourage students to ask the langer questions that lie beyond the bounds of most traditional courses. Not only does service-leaming have the potential to help students learn the content in a particular discipline, it also asks students to consider the context of a discipline and how its knowledge base is used in practice. This experience works best when it is used to meet course objoctives. If service is an add-on that is not designed to advance the objectives of a course or does not help students learn course content, it degrades the academic integrity of the course.

Intensive Service-Learning Experiences

Service is considered intensive when students dedicate themselves to an experience for a significant portion of their time, more than ten hours a woek, for a sustained period of time. Through this process, students begin to see how classroom theory applies to $\cdots$ real-world issues and to rocognize the interdisciplinary nature of problems and solutions. These experiences often lead students into a lifelong commitment to socially responsible citizenship. Examples might include study abroad, AmeriCorps, Break Away altemative breaks, independent studies, and internships.

Integrating Service-Learning Experience into Postcollege Choices People live richer lives when they are able to view career, relationship, location and lifestyle as a coherent whole. Commitment to social justice is a way of life that all individuals can choose rather than a separate activity to be done around the edges of other commitments. Examples might include AmeriCorps, the Peace Com Hahitat for Humanity. World Teach, Teach for America. 


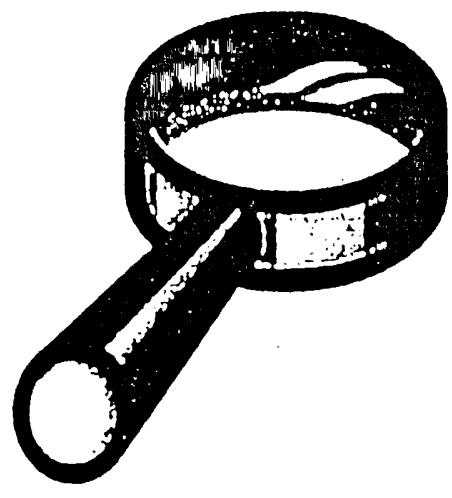

\section{REFLECTION}

Reflection is a key component of community service and it provides the critical connection between service work and academics. It is the medium by which learning takes place. Reflection provides the opportunity for students to process what they have done and to think critically about their experience.

\section{METHODS OF REFLECTION}

Reflection can occur through many methods such as writing, speaking, listening, reading, etc.

Suggested forms of reflection:

Joumal Writing - record elements of the service experience

Directed Writing - respond to specific question areas about the service

Directed Readings - students read specific materials related to the service

Class Discussions - discussions which require processing of the service work

Ethical Case Studies -work through case studies in a discussion group

Student Portfolios - collections of service related items

Story Telling - sharing stories about the service experience

Class Presentations - poster displays/debates

Experiential Research Paper - research larger issue related to service work

Electronic Mail Discussions - use technology to expand service opportunities

\section{REFLECTION FOCUS AREAS}

It is important that Reflection focus on three areas:

Focus on Self - What did the student actually do and how.did it make them foel?

Who am I?; What are my values?

How will this experience change the way that I act or think in the future?

Focus on Others - How did the service help others and why is that important?

What did I learn about the people that benefited from this service work?

How did my actions impact others?; What more needs to be done in this service area?

Focus on the Big Picture - How does service affect the larger community?

How is the issue/agency that benefited from the service work impacted by elements in politics or society?

What will the future be like for this service area?

What can be done?; How can I affect future change? 


\section{SERVICE - LEARNING \\ SEMESTER OUTLINE}

\section{Q $B E F O R E$ SEMESTER BEGINS}

- THE O.V.Al. OFFICE WILl CONTACT FACULTY INVTTING THEM TO

PARTICIPATE

MEETINGS WILL BE SCHEDULED TO CONFIRM INVOL VEMENT

- INTRODUCE TRAINING MANUAL

- OUTLINE SPECIFIC SUBJECT (COURSE).

- DISCUSS SPECIFIC TYPES OF VOLUNTEER PROTECTS

$\checkmark$ FACULTY MAKES COMMTTMENT

- INCORPORATES SERVICE LEARNING INTO THEIR SYULABUS

\section{Q FIRST TWO WEEKS OF CLASS}

- PROFESSOR INTRODUCES SERVICE-LEARNING TO STUDENTS

- EMPOWERS STUDENTSCOMMTTMENT TO VOLUNTEER WORK

- EMPHASLZES FUL FILLMENT

$\checkmark$ THE O.V.AL. OFFICE PRESENTS SERVICE LEARNING TO CLASS

- BRINGS VOLUNTEER OPPORTUNITIES TO STUDENTS

- INCORPORATES SERVICE-LEARNING APPLICATIONS

- DISCUSSES PROCESS

O INTRODUCES THEM TO ALL PAPERWORK

\section{MID SEMESTER}

$\checkmark$ CONFIRM THAT ALL STUDENTS ARE PERFORMING VOLUNTEER WORK

- TAKE Cl.ASS ROSTER TO THE O.V.AL. OFFICE

- ENCOURAGE DIALOGUE WITH STUDENTS REGARDING THEIR EXPERIENCES

\section{Q}

\begin{tabular}{|l}
\hline STUDENT/AGENCY EVALUATIONS SHOULD BE PASSED OUT AND \\
COMPLETED \\
O TDME SHEETS WILL BE TURNED IN TO FACULTY \\
O JOURNALS WII BE SUBMTTIED ALONG WTTH ALL FORMS \\
$\qquad \begin{array}{l}\text { INCORPORATE STUDENTS PERSONAL EXPERIENCES INTO YOUR } \\
\text { CLASSROOM ACTIVTTIES } \\
\text { ALL FORMS AND JOURNALS WTL BE TURNED INTO THE O.V.AL. } \\
\text { OFFICE AT COMPLETION OF SEMESTER }\end{array}$ \\
\hline
\end{tabular}

Any questions, concerns and problems should be directed to The O.V.A.L. Office on your campus. 


\section{The O.V.A.L. Office}

Introduces

Service-Learning

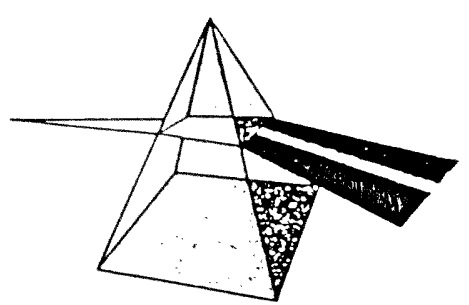

What is Service-Learning?

Service-Leaming refers to the integration of community service in an organized setting where the servers reflect upon the meaning of their service. The idea behind servicelearning is that by combining the service with a reflective education structure, powerful benefits that go beyond what either service or learning can offer separately will be created. By combining service and learning individuals who perform the services will be able to make a connection between their course study, work and the underlying values and issues behind the social problem being addressed. Where servers use the experience in the community as a basis for critical reflection and leadership. Students can better examine democratic communities and the role of the citizens in them. They can develop a habit of critical reflection on their experiences enabling them to learn more throughout life. Service and learning bring citizens from different backgrounds or settings together to do common work, and through reflection, learn more about each other and respect each other's cultural differences. 


\section{Broward Community College Central Campus \\ 3501 SW Davie Road \\ Davie, Florida 33314}

Volunteerism/Service Learning - Student Referral

Dear Volunteer Coordinator:

At BCC we are committed to providing our students opportunities to supplement textbook leaming through the hands-on experience of volunteerism and/or service-leaming. Your support helps make a wide variety of resources available to our students.

The student presenting this letter, has expressed a desire to volunteer with your agency. If you foel he/she meets the needs of your agency and you would like to accept him/her as a volunteer, please complete the section below and return this form to our office.

If I can be of assistance, please feel free to contact me at (954) 475-6756. Thank you again for your support.

Cordially,

Liz Atchisan

Liz Atchison, Coordinator

Student Life Department

Agency information

Agency mame

Address

Phone number

Number of hours nooded per woek

Name of supervisor-please print

Supervisor's signature

Please raum complaed form to the Student Life Office, Building 19, Room 108 


\section{THE O.V.A.L. OFFICE \\ OfFice of VolunteERSM AND Leadersm \\ BROWARD COMMUNTTY COLLEGE \\ VOLUNTEER \\ SERVICE INTEREST FORM}

DATE:

CAMPUS:

NAME:

SSH:

ADDRESS:

MANOR:

PHONE:

BEEPER:

IS THIS FOR SERVICE-LEARNING CREDTT YES

IF YES, PROFESSORS NAME

NO

COURSE

1. List any spocial stalls: (ie. bi-lingual, ompurter literate, musical instruments)

2. List any previous voluntoer experience and where:

3. Would you be interestod in bcing an "ON CALL VOUNTEER"?

4. List hours availabic for voluntocring or list class and/or work schodules on back of this form.

\section{PLEASE CIRCLE AREAS OF INTEREST:}

Animas Riglus

Education/Tutoring

Health Services

Abuse Preventioa

Womer's Servioes/Pregnancy

Spocial Events

Voluntoering on campus
Disability Services

Elderly Services

Hunger and Homelesmess

Disease/AIDS Prevention

Religious Services

Youth Programs
Disecter Relief Enviroamental Losues Cultural/Arts

Substance Abuse

Social/Civic Lsoucs

Other

I understand that public relations is an important part of the work of voluntoers at Broward Community College and I agroc to allow Broward Commurity College to use any pholographs taken of me while performing volunteer services for Broward Commucity College, for use in public relations cflorts. 


\section{BROWARD COMMUNITY COLLEGE}

\section{STUDENT VOLUNTEER VERIFICATION AND TIME SHEET}

Please nisinasin this sime sheel as verification for volunteer hours. This sheet, if maintained properly, will serve as tho proof necessary to confirm your voluntecrism for your

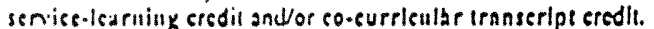

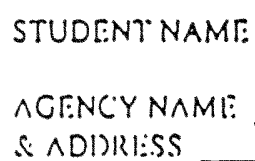

TOTAL HOURS

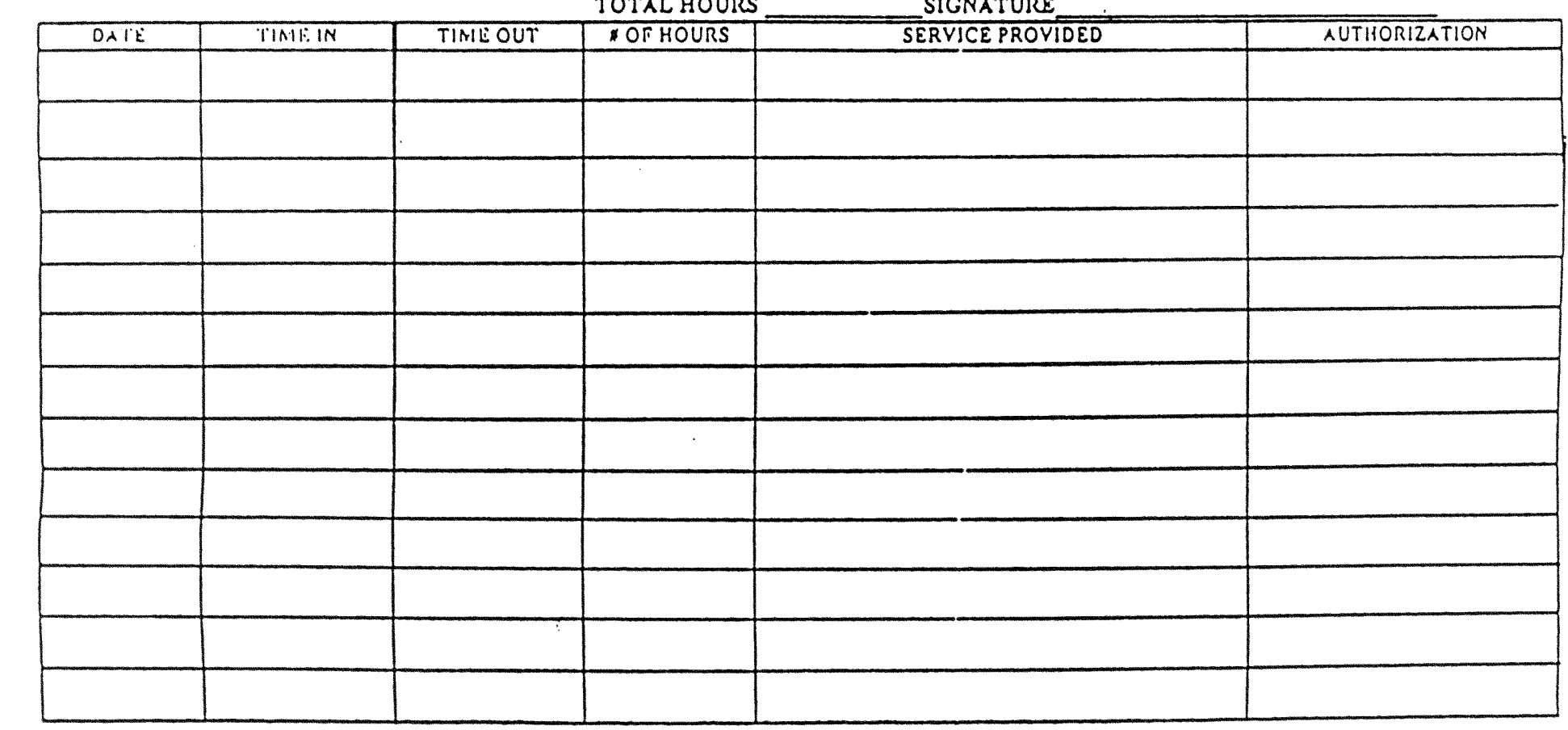
AGENCY SUPERVISOR (1) OR SUPETYYISORS SUPERVISORS

SIGNATURE 


\title{
oist \\ THE O.V.A.L. OFFICE \\ Office of Volunteerism And Leapersim BROWARD COMMUNTTY COLLEGE
}

\author{
AGENCY INTRODUCTION \\ $\&$ \\ CONFIRMATION LETTER
}

Date:

Attention Sarvice Agency:

is currantly carollod at Browned Community College, majoring in and intarestod in voluntocring with your arganization.

This student is responding to our office of woluntoerism and Voluntoer Broward diroctary listing's. We hope hisher abilities and interests match your voluntoer noods. Upon acoepting this studeat voluntoer, we ask that you siga the bottom of this letter and have the student return it to us.

BCC"s office of voluntocrism and leadership is committod to providing students an opportunity to gain real-life expericace to supplement textbook learning. We bope our students will be an asset to your agency.

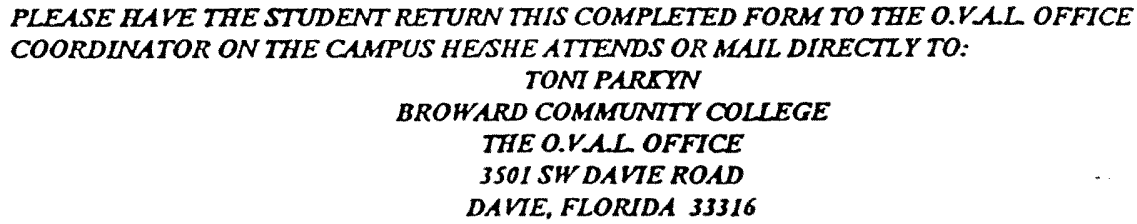

Frudene Name)

beginning oo will be voluntocring at

$$
\text { Meancy Nome) }
$$

$$
\text { (Dore) }
$$

Agency Phooc \# 


\section{THE O.V.A.L. OFFICE \\ Office of Volunteerusm And Leadership \\ BROWARD COMMUNTTY COLLEGE \\ STUDENT SERVICE EVALUATION}

The O.V.A.L. Ofice at BCC is interestod in the efforts of BCC student voluntoers. In onder to better serve both our students and our community, we neod to asseoss the impact of our students on an individual basis. Please take a moment to complete this evaluation.

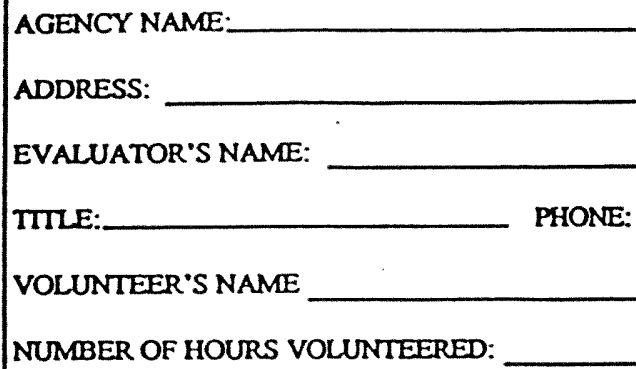

PLEASE CIRCLE THE RESPONSE THAT BEST REFLECTS YOUR SENTMMENTS:

( 1 is RARELY and 6 is ALWAYS)

1)

The volunteer is punctual.

$\begin{array}{llllllll}\text { rendy } & 1 & 2 & 3 & 4 & 5 & 6 & \text { aheys }\end{array}$

2) The voluntoer is considerate and polite.

$\begin{array}{lllllllll}\text { rardy } & 1 & 2 & 3 & 4 & 5 & 6 & \text { atrays }\end{array}$

3) The voluntoer is reliable, consistent and acomplishes assignod tasks.

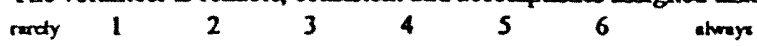

4) Please rate the importance of the voluntcer's contribution to your agency.

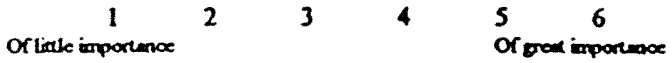

5) This wolunteer has been working with:

(please include job description, continue on back if necessary) 


\author{
DOING WELL BY DOING GOOD: \\ A STUOY OF THE EFFECTS OF A \\ SERVICE-LEARNING EXPERIENCE \\ ON STUDENT SUCCESS
}

$\frac{\text { Judith S. Berson, Ed.D }}{\text { Broward Communing Colloge }}$

William F. Younkin, Ph.D.

University of Mlaml

\begin{abstract}
This study explored the efrects of a service-learning experifence on studeat success. Studeats earolled in six paired community college courses in varlous disciplines participated in a quastexperim catal study that cxplored the effects of a servlce-tearalag experieace on succeas as measured by class attendance, course completion, final course grade, and end-of-term evaluation data. The results indicated that, overall, students who participated In the sections with a 20-hour service-learaing requiremeat achicved bigher fpal course grades and reported greater satisfaction with the course.
\end{abstract}

In the Talmud, the Rabbis teach us that "Good deeds are better than wise sayings." Today we would say "actions speak louder than words" or, to be more hip. "walking your talk" beats just talking. While there is no doubt that the primary role of higher education is academic, the goal of educators is also to develop graduates who are fully functioning members of society. It is often out-of-class activities that produce our most valuable citizens and community leaders. As the information age dramatically changes our definition of the nature of work. educators face a dual challenge of preparing students to be productive in today's highty competitive marketplace whide imparting the values necessary to sustain us as a society (Harkavy, 1995; Rifkin, 1996).

\title{
Introduction
}

Colleges and universities across the nation are embracing volunteerism and student community service programs as antidotes to a society suffering from disengagement, disinterest, and disenchantment. However, in this era of accountability and educational reform, "doing good" for good's sake is not enough. To obtain needed funding. educational institutions are mandated to document specific student outcomes, thus students must also "do well." Beyond stepped up attempts at self-assessment and program evaluation, college administrators and faculty are continually searching for new ways to help students learn and graduate. Empirical evidence is needed to measure the effect of service experiences on student success.

Today, for malions of Americans, community colleges are often the only means to access higher education. Though applauded by many as the premier providers of affordable educational services, these open door "people's colleges" are frequently criticized for becoming revolving doors. Research indicates that high school graduates who intend to pursue higher education are less likely to succeed if they begin their studies at a two-year institution (Pascarella \& Terenzini, 1991). Innovative programs, processes and teaching methods are continually explored and tested by community college leaders striving to create true leaming organizations (Bumphus, 1896). One exciting motivational strategy is the introduction of community service into the curriculum through service-leaming (Enos \& Troppe, 1996), an educational practice that links education and social responsibdity through active leaming. Since its entry into college and university campuses in the $1960 \mathrm{~s}$, service-leaming has provided a linkage between community service and classroom instruction, using reflection to develop critical thinking skills and a sense of cric responsibility (Kendall, 1990).

Service-feaming is multifaceted. One aspect is as a course-related pedagogical method utilizing experiential 
education to teach citizenship, academic subjects, skills, and values. The lessons are drawn trom a service experience that meets community needs combined with critical reflection on the service to gain further understanding of the course content, a broader appreciation of the discipline, and an enhancod conse of civic responsiblity. Students work in a wide range of projects, e.g., assisting in community agencies, participating in environmental projects, tutoring. mentoring, or providing services to at-risk populations.

Alexander Astin (1991), a well known researcher who has monitored the values of hooming first year college students since the 1970 s, found students of the 1960 s to be "markedly more materialistic and more concerned with having power and status" (p. 57). Colleges and universities cannot afford the luxury of insulating themselves from such soctal issues as homelessness, iliteracy, teen pregnancy, dropouts, substanco abuse, juvenile offenders, and the elderly (Harkavy, 1985). A vital means by which colleges support such leaming is by imbedding such experiences directly into the curriculum (Bringle \& Hatcher, 1996). Professors throughout the country have been introducing service components into their courses. There is general agreement among advocates of public service as a fundamental mission of higher education, that academic programs and service must be combined (Hirsch. 1996: Bradfield \& Myers, 1996). According to Kupiec (1992), the strategy of refocusing academic programs to help to "solve concrete, immediate real world problems... [will] advance higher education and human welfare" (p.3).

Service-leaming appeals to people for a variety of reasons. In a speech at a conference on leaming communities, noted educator K. Patricta Cross (1997) stated that "some are attracted to Dewey's experiential notions of leaming while doing: some like the disciplinary integration that is required in addressing real problems; some regard reflection on experience as critically important to deeper learning; some like the community involvement that is required-not only participation in the college service-leaming communtly, but participation in a wider non-university community as well; some are attracted by the experience with diversity that students get when they participate in a community that is usually very different from any university community; some tike the moral dimension of social responsibality. some like the affective aspects of compassion and empathy that are presumably developed through service-leaming."

Service-leaming is basically a form of experience-based leaming. The primary differenco between experiential education and service-learning is the focus. The former benefits the student, while the focus of the latter is two-fold in that service-leaming is reciprocally beneficial to the student as well as the community, with the emphasis on the community (Cohen \& Kinsey, 1994; Kendall, 1990; Kraft \& Krug. 1994). Service teaming can be an option in a traditional course, a course requirement, or the focal point of a service course. Any course can be designated as a service-learning course as long as the instructor agrees to inject a reflection component that relates the course content with the service issue. With national attention being paid to the lofty goals that service-teaming endeavors to achieve, it cannot be viewed as "merely a faddish add-on to an already overburdened curricular reform agenda" (Battistoni, 1995, p. 34).

Nevertheless, student community service in general and service-feaming in particular are often viewed as extracumicular or co-curricular activities. In light of the fiscal belt tightening that prevalis in this country today, funding for service-leaming initiatives is often edipsed by academic program needs. If service-leaming is to become accepted by faculty and academic administrators as an integral part of the curriculum, data are essential to make the case that service-leaming has an effect on academic success.

Most studies do not address today's student, especially today's community college student. The community college student of today is typically older, commutes, attends classes part-time, has family responsibilies, works at least 20 hours a week, and is racially or ethnically diverse (Kuh and Vesper, 1991; Pascarella and Terenzini, 1991). For these students, academic goals often compete for time spent with their families, work, and community activities.

\section{Methodofogy}

This study of the relationship between a service-leaming experience and academic success was guided by Tinto's Student Integration Model (Tinto, 1987). Tinto (1987) theorized that student intentions and commitments when they enter higher education are subsequently modified through a series of "interactions between the individual and the structures and members of the academic and social systems of the institution" (Pascarella \& Terenzini, 1991, p. 51). He contends that student retention, and ultimately student success, is a direct result of "satisfying and rewarding encounters with the formal and informal academic and social systems of the institution" [and is] "presumed to lead to greater integration" Pascarella \& Terenzini, 1991, p. 51). Tinto's model has been used successfully to study many student outcomes in addition to college attrition, e.g. academic skill acquisition, personal change. major changes, and his theory of departure (Pascarella \& Terenzini, 1991). However, since much of Tinto's work has focused on students at four-year institutions, it is important to determine whether the same concepts and 
approaches that are applied to traditional students attending traditional institutions can adequately describe the student experiences at community colleges. Tinto's model provides an explicit theoretical structure which "offers significant opportunities both to researchers who wish to study the college-to-student change process and to administrators who seek to design academic and social programs and experiences intended to promote students' educational growth" (Pascarella and Terenzini, 1991, p. 53).

Pascarella and Terenzini suggest that, since "some of our most cherished notions about the determinants of impact may have little relevance to these [community college] students" (p.632), investigations into college effects on students should be refocused on the vast numbers of students who, although usually classified as "nontraditional," are "rapidly becoming the majority participants in the American postsecondary system" (p.632). Knight (1994) agrees that more studies are needed on community college students where their "backgrounds and goals and the type and scope of student involvement opportunities may be unlike those for senior institutions" (p. 3-4).

\section{Prior Research}

Although there is growing interest in studying the effect of service-leaming activities on student development (Luce, 1988), there are still important issues that need to be addressed. The limited number of replicable studies and empirical evidence on the impact of service experiences (Miller, 1994) is even more critical for community colleges where, according to a 1995 survey, $75 \%$ of community colleges are either actively involved in or interested in offering service-leaming on their campuses.

There are a variety of issues to examine when assessing service-leaming outcomes. Typically, proponents suggest that two central questions be addressed:

"1) What is the effect of service-leaming on the intellectual, moral, and citizenship development of participants? and 2) What is the effect of service-leaming on the advancement of social institutions and democracy?" (Giles, Honnet \& Migliore, 1991).

Whereas previous studies examined the effect of a service-leaming experience on student perception of their personal growth (Miller, 1994), social attitudes (Markus et al., 1993), moral reasoning (Boss, 1994), and cognitive, moral and ego development (Batchelder \& Root, 1994), this study examined student academic success. It attempted to answer several critical questions, namely: What effect does participation in service-learning have on students in terms of final course grade, class attendance or course completion?" "Is there a significant improvement in student knowledge or skilis as a result of their participation?" "Did students expend more effort and display greater satisfaction with the course and the instructor because of the service-leaming requirement?" "What were the issues and opportunities for faculty who added the service-learning requirement to their course?"

Markus et al. (1993) conducted one of the few studies that attempted to isolate the effects of service-learning on academic achievement. The researchers used a randomized control group design to compare sections of political science classes with and without a service-leaming component. By randomly assigning the community service activities, they controlled for student achievement levels. However, as in many similar studies, the students in the control group were required to write longer term papers based on ibrary research than students who participated in the service activities (Markus et al., 1993). Nevertheless, the results indicated higher scores on mid-term and final examinations, a significant increase in favorable course evaluations, and the students who performed community service demonstrated more positive attitudes toward service and the community.

\section{Methodology}

The study consisted of 286 students enrolled in six paired courses taught by five instructors (one instructor taught two paired courses). One section of each pair (the control group) was taught using traditional subject matter and course materials and the other section of each pair (the treatment group) was required to participate in a 20-hour senvice-leaming activity in addition to the regular course curriculum. The courses in the study included American History, Sociology. College Preparatory English, and Introduction to English Composition.

A quasi-experimental nonequivalent control group design was used to examine the effects of the service-learning experience on the students. The students self-selected the section they enrolled in, without any knowledge of the experiment. The results of this enrollment process appears to be essentially random (see Table 1). When service-learning is offered as a course option and student participation is voluntary, it is difficult to know whether gains are a result of the student's initiative and motivation, or are truly an effect of the treatment. Two traditional measures of student success and persistence are grades and attendance. Thus, this study involved collecting data 
The students did not know about the service requirement in advance and both groups of students were assessed by the instructors using the same exams and assignments. Instructors provided data on student attendance.

Withdrawals, final course grade, and course completion data were obtained from official college records. A post-term survey was administered to the students to assess their attitudes about the course material, satisfaction with the course and perceived level of effort they exerted in the course. In addition to the student data, participating faculty were assessed using a focus group, a beginning-of-term survey, an end-of-term survey, and personal interviews to examine faculty attitudes about the course sections and their experience.

Most of the studies that have been done on the effects of service-learning on academic outcomes were conducted in selective four-year universities where the majority of students were recent high school graduates, attended full-time, and resided on campus. Therefore, there is limited research on the effects of service-learning on non-traditional students attending community colleges, or on students enrolled in college preparatory courses.

\section{Results}

The study involved data collection using college records, faculty records, and survey-type instruments. One instrument provided for the assessment by faculty of their expectations about the outcomes of the experiment, another assessed faculty reflections at the end of the term, and the third instrument assessed students' attitudes toward the course, the instructor, their perceived level of effort, and the grading system.

The results of the study indicated that, overall, students who participated in a class in which service-learning was a requirement achieved higher final course grades and reported greater satisfaction with the course, the instructor. the reading assignments, and the grading system (see Table 2). In addition, the faculty members reported that, in the treatment sections, class discussions were more stimulating, the sections seemed more vital in terms of student involvement, the students seemed more challenged academically, more motivated to learn, and seemed to exert more effort in the course.

This confirms Pascarella and Chapman's conclusions (1983) based on applying Tinto's model to non-residential college students, that "commitment to the institution... is defined largety by successful and personally-satisfying interactions with the academic rather than the social systems of the institution" (p.95).

In addition to the fact that the mean final course grades were 26 higher for the students in the treatment group. there was also a significant difference in the level of student satisfaction as reported in the end-of-term student questionnaire. In 15 out of 17 end-of-term evaluation criteria, students in the treatment group gave higher ratings to statements concerning satisfaction with the course, the instructor, and their grades in the course. The difference was significant in all three of the criteria related to grades $(p<.05)$. Students in the treatment group were more likely to report that their grade was "a fair assessment" of their performance, that the grading system was "clearly defined," and that the exams "covered important aspects of the course."

Data were also collected from the seven participating faculty members to determine motivations and reactions to their participation in the study. Two questionnaires were administered and one-on-one intervins were conducted with each of the participating faculty members. Although the faculty reported that they would offer service-teaming as an option in future courses, they did not agree that they would elect to make it a requirement.

\section{Conclusion}

Employers are demanding more from our graduates than skill in the disciplines. More and more they are seeking workers who can communicate effectively and have developed skills in problem-solving. critical thinking, and reflection. To prepare our students to meet the coming challenges, student affairs and academic affairs professionals must find ways to collaborate. Service-learning is one of the best strategies for bridging the gap between these two vital areas in order to enhance student success.

It is generally accepted that service participation has a positive effect on students' ethical and social values, leadership ability, social skills, self-esteem, concern for others, racial understanding, commitment to continued senice, and critical decision-making ability (Kendrick, 1996). However, service-leaming is viewed as a philosophy of education as well as a program type. As an educational philosophy, data are needed to substantiate the academic benefits to students in addition to ethical, social, and personal development benefits. In this regard, research on experiential education and leaming styles is of some use. This study lends credence to the theory that 
service-learning experiences lead to higher levels of involvement and performance. At commuter institutions grades tend to be in direct relation to a student's commitment whereas attendance and course completion is subject to external influences not always under the student's control. Further research is necessary to be able to substantiate the causal links.

\section{Bibllography}

Astin. A.W. (1991). Assessment for excellence: The philosophy and practice of assessment and evaluation in higher education. New York: American Council on Education MacMillan Publishing Company.

Batchelder, T.H. \& Root, S. (1994). Effects of and undergraduate program to integrate academic learning and senvice: Cognitive, prosocial cognitive, and identity outcomes. Joumal of Adolescence. 17, 341-355.

Battistoni, R. (1995, Winter). Service leaming, diversity, and the liberal arts curriculum. Liberal-Education. 30-35.

Boss, J.A. (1994). The effect of community service work on the moral development of college ethics students. Joumal of Moral Education, 23(2), 183-198.

Bradfield, C.D. \& Myers, R.A. (1996, March-Apri). Practice in enriching the student learning experience through community senice learning." About Campus.

Bringle, R.G. \& Hatcher, JA. (1996, March/Aprii). Implementing Service Learning in Higher Education. Joumal of Higher Education. 67 (2), 221-239.

Bumphus, W.G. (1996), Aug/Sept). Dare to dream the dream. Community College Joumal. 67 (1), 3.

Cohen, J. \& Kinsey, D. (1994, Winter). 'Doing good' and scholarship: A Service-Leaming Study. Joumalism Educator. 4-14.

Conrad, D. \& Hedin, D. (1991). School-based community service: What we know from research and theory. Phi Delta Kappan. 72, 743-749.

Cross, K.P. (1997, January). Keynote Address Presented at the Transforming Campuses into Learning Communities Conference, University of Miami, FL.

Enos, S.L. \& Troppe, M.L. (1996). Serviceteaming in the curriculum. In Jacoby, B. Service-Leaming in Higher Education. 156-181.

Giles, D.; Honnet, E.P.; \& Migliore, S. (1991). Research agenda for combining service and leaming in the 1990s. Raleigh, NC: National Society for Experiential Education.

Harkavy, I. (1995, June). Summary of Workshop Presented at the Campus Compact Center for Community Colleges $4^{\text {th }}$ National Conference, Scottsdale, AR.

Hirsch, D. (1996, May). An agenda for involving faculty in service. AAHE Bulletin 48(9), 7-9.

Kendall, J.C. \& Associates. (1990). Combining service and leaming a resource book for community and public service. Raleigh, NC: National Society for Intemships and Experiential Education.

Kendrick, J.R. (1996) Outcomes of service-learning in an introduction to sociology course. Michigan Joumal of Community Service-Learning. 72-81.

Knight, W.E. (1994, June). Influence on the academic, career, and personal gains and satisfaction of community college students." AIR 1994 Annual Forum. 
Kraft, R.J. \& Krug. J. (1994). Review of research and evaluation on service learning in pubtic and higher education. In Kraft, R.J. \& Swadener, M. (Eds.), Building community: service leaming in the academic discipline. Denver, CO: Colorado Campus Compact.

Kuh, G.D. \& Vesper, N. (1991, November). Influence on student leaming at metropolitan institutions. ASHE Annual Moeting.

Kupiec, T. (1992,Spring). The project on integrating service with academic study. Compact Nows. 6(1).

Luce. J. (Ed.). (1988). Service-leaming: An annotated boliography linking public service with the curriculum. Raleigh, NC: National Society for Experiential Education. In Combining service and leaming: A resource book for community and public service. Vols. III. Raleigh, NC: National Society for Intemships and Experiential Education.

Markus, G.B., Howard, J.P.F., \& King. D.C. (1993, Winter). Integrating community service and classroom instruction enhances leaming: Results from an experiment. Educational Evaluation and Policy Analysis., 15(4). 410-419.

Miller, J. (1994, Fall). Linking traditional and service-teaming courses: Outcome evaluations utilizing two pedagogically distinct models. Michigan Joumal of Community Service Leaming. 1(1). 29-36.

Pascarella, E., \& Chapman, D. (1983). A multi-institutional, path analytic validation of Tinto's model of college withdrawal. American Educational Research Joumal, 20. 87-102.

Pascarella, E.T. \& Terenzini, P.T. (1991). How college affects students. San Francisco: Jossey-Bass.

Rifkin, J. (1996. April/May). Preparing the next generation of students for the civil society. Community College Joumal. 20-23.

Tinto, V. (1987). Leaving college: Rethinking the causes and cures of student attrition. Chicago: University of Chicago Press. In Pascarella and Terenzini (1991). How College Affects Students. San Francisco: Jossey-Bass.

\section{Authors}

JUDITH S. BERSON, Ed.D is Associate Vice President for Student Affairs and Director of Student Financial Services at Broward Community College, Fort Lauderdale, FL, and is well known for her FIPSE-funded innovative service learning programs involving college students mentoring at-risk youngsters. She is also a lecturer in higher education at Florida International University and president of Educational Empowerment Institute, Miami Beach, FL. a firm specializing in employee training programs. She is the author of two books and several articles including $A$ marriage made in heaven: community colleges and service-leaming and Winwinwin with a service-leaming program.

WILLIAM F. YOUNKIN. Ph.D. is a lecturer in Management Science in the School of Business at the University of Miami, Coral Gables, FL, and is president of Educational instruction Systems, inc., a consulting firm specializing in program evaluation. He is an associate of the Center for the Study of Quality in Service and Manufacturing and is active in conducting workshops and training seminars on the use of statistics in quality improvement. Prior to becoming a teacher and consultant, Dr. Younkin was a university administrator, holding positions including University Registrar and Director of Institutional Research. 


\section{Richard Appelbaum}

\section{EXPERIENCE}

1977 - present

ESL/English Instructor

Adjunct Spanish Instructor

Broward Community College, Fort Lauderdale, Florida

1979-1987

International Student Coordinator

Broward Community College, Fort Lauderdale, Florida

1991-1996

English as a Second Language Coordinator

Broward Community College, Fort Lauderdale, Florida

1976-1979

International Government and Diplomacy Instructor

Nova University, Fort Lauderdale, Florida

1971-1976

Social Science Department Chairperson

Palmer Preparatory School, Miami, Florida

1969-1971

English as a Second Language Instructor

Centro Venezolano-Americano, Caracas, Venezuela

1967-1969

Assistant Dean of Men

Wagner College, Staten Island, New York

\section{EDUCATION}

Dissertation in progress for Ed.D.

Florida International University

Master of Science (1969)

Inter-American Studies

English as a Second Language

State University of New York Albany 
Master of Arts (1967)

Comparative Government and History

Student Personnel and Guidance

State University of New York at Albany

Bachelor of Arts (1965)

History and Political Science

Adelphi University

\section{AWARDS}

Finalist: Professor of the Year 1998, 1999

Teaching/Learning Center Award

Computers in the Classroom Grant

Phi Kappa Phi Honor Society Award

Letter to the Editor Award, The Herald

National Association for Foreign Students Research Grant

Graduate Assistantship Award, SUNY at Albany

\section{PROFESSIONAL ORGANIZATIONS}

National Association for Foreign Students, South Florida Liaison

Teachers of English as a Second Language Association

Florida/Sunshine State Teachers of English as a Second Language

South Florida Educational Consortium, Program Director (1979-80)

\section{COLLEGE COMMITTEES AND ACTIVITIES}

International Education Committee

Equal Access/Equal Opportunity Committee

Provost's Advisory Committee, Central Campus

TLC Committee

Mentor Program

International Student Club Advisor (1979-87)

Vietnamese Student Club Advisor

Service-Learning in the Classroom 